Fall 1924

\title{
1924 Cedrus Yearbook
}

\section{Cedarville College}

Follow this and additional works at: https://digitalcommons.cedarville.edu/yearbooks

Part of the Higher Education Commons, Organizational Communication Commons, and the Public Relations and Advertising Commons

\section{Recommended Citation}

Cedarville College, "1924 Cedrus Yearbook" (1924). Yearbooks. 88.

https://digitalcommons.cedarville.edu/yearbooks/88

This Book is brought to you for free and open access by DigitalCommons@Cedarville, a service of the Centennial Library. It has been accepted for inclusion in Yearbooks by an authorized administrator of DigitalCommons@Cedarville. For more information, please contact digitalcommons@cedarville.edu. 


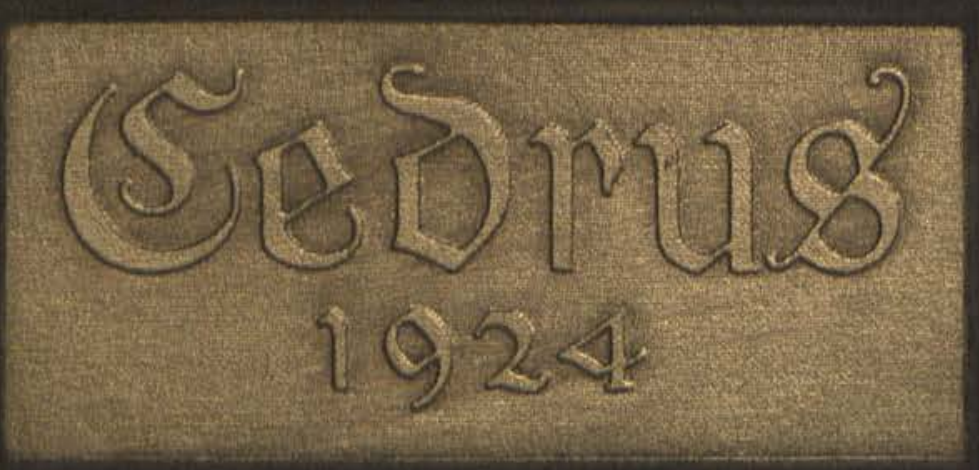




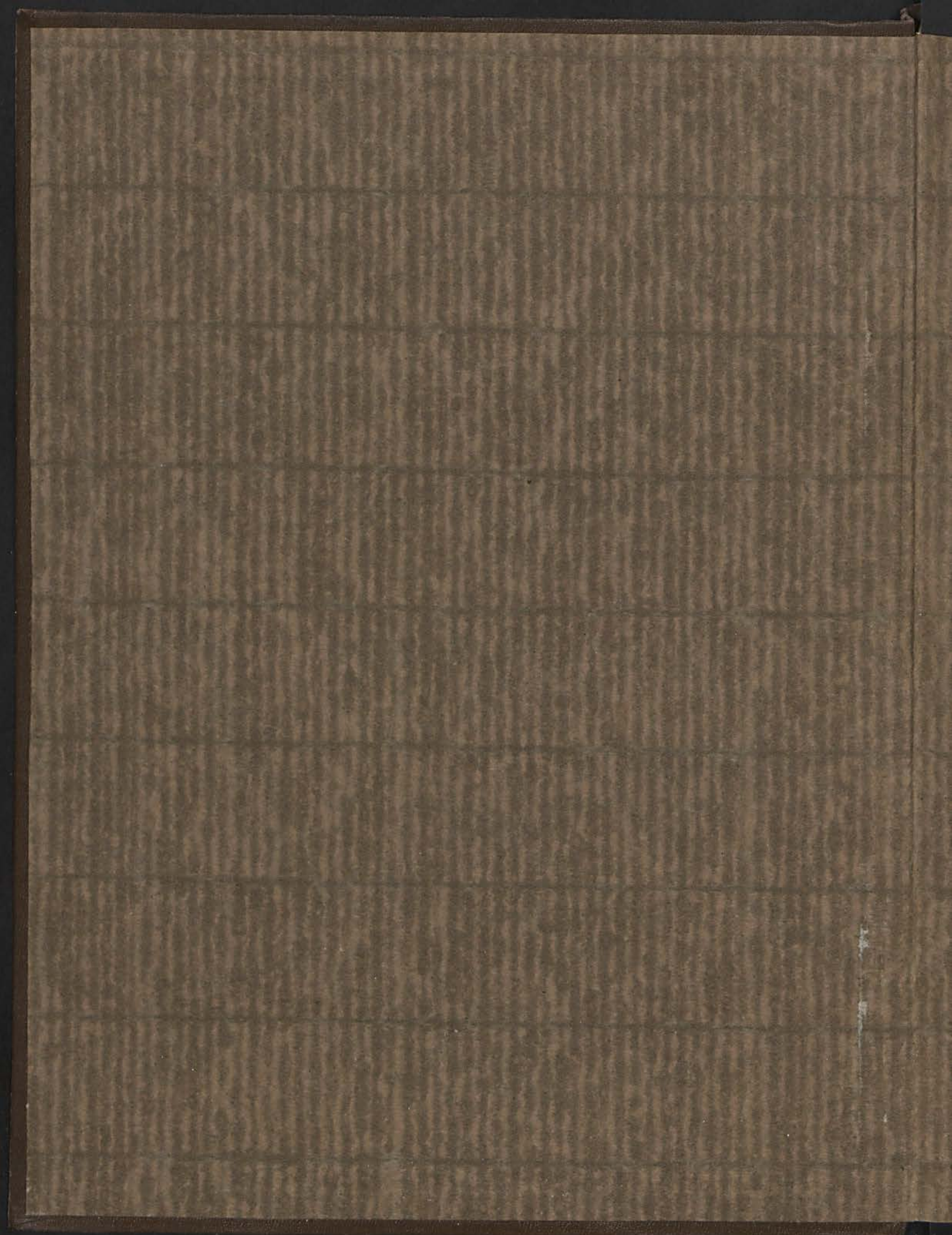





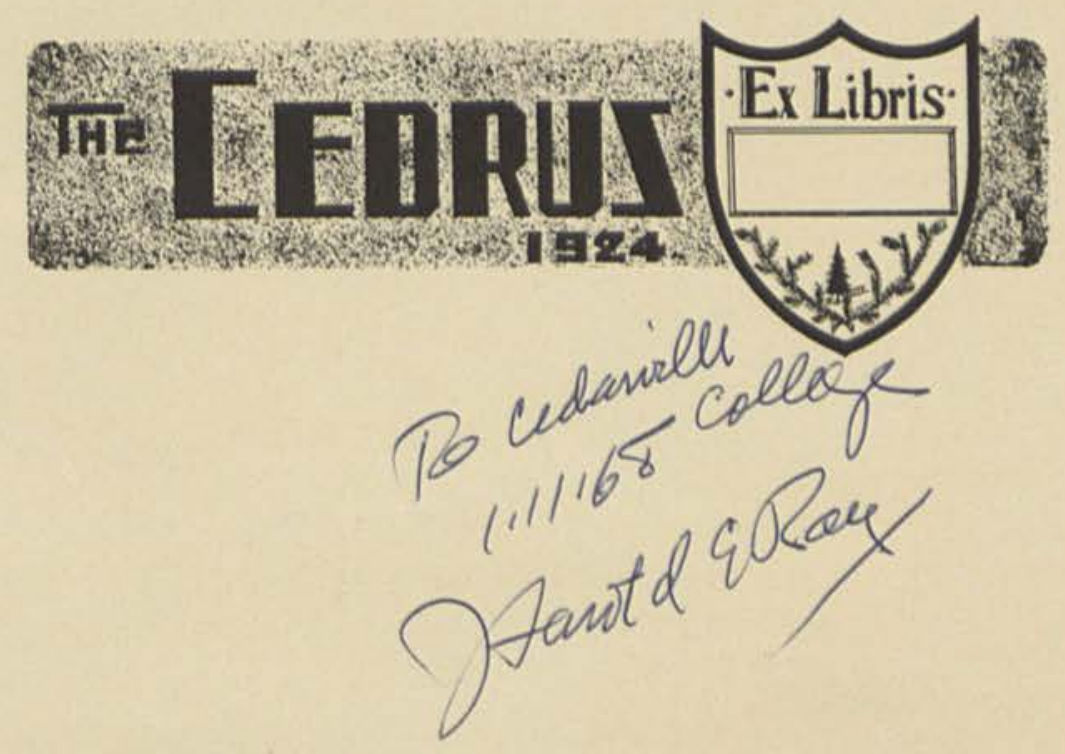




\section{COMPILED BY \\ THE \\ CEDRUS STAFF \\ of \\ I 924}




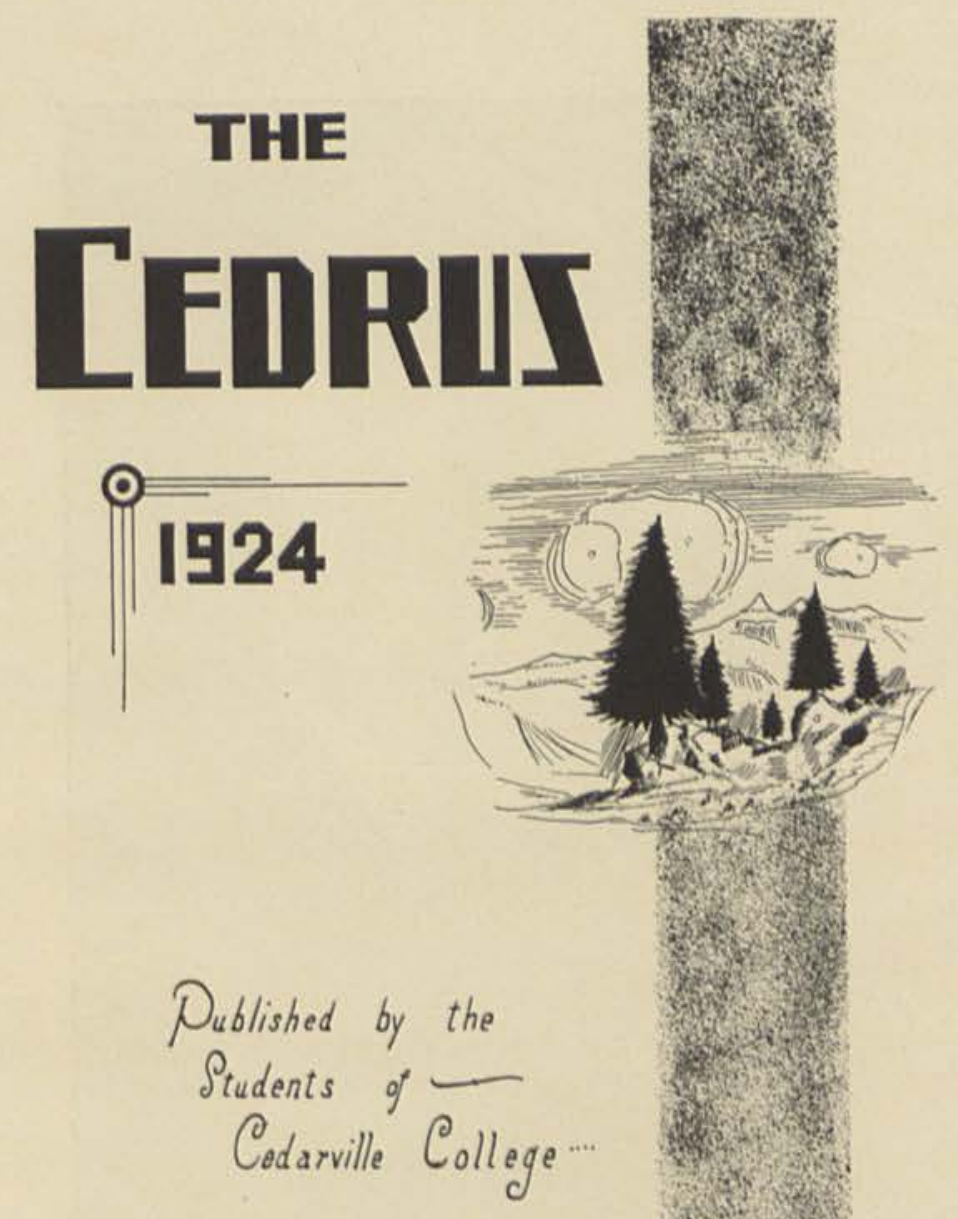

(17)

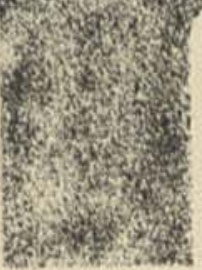




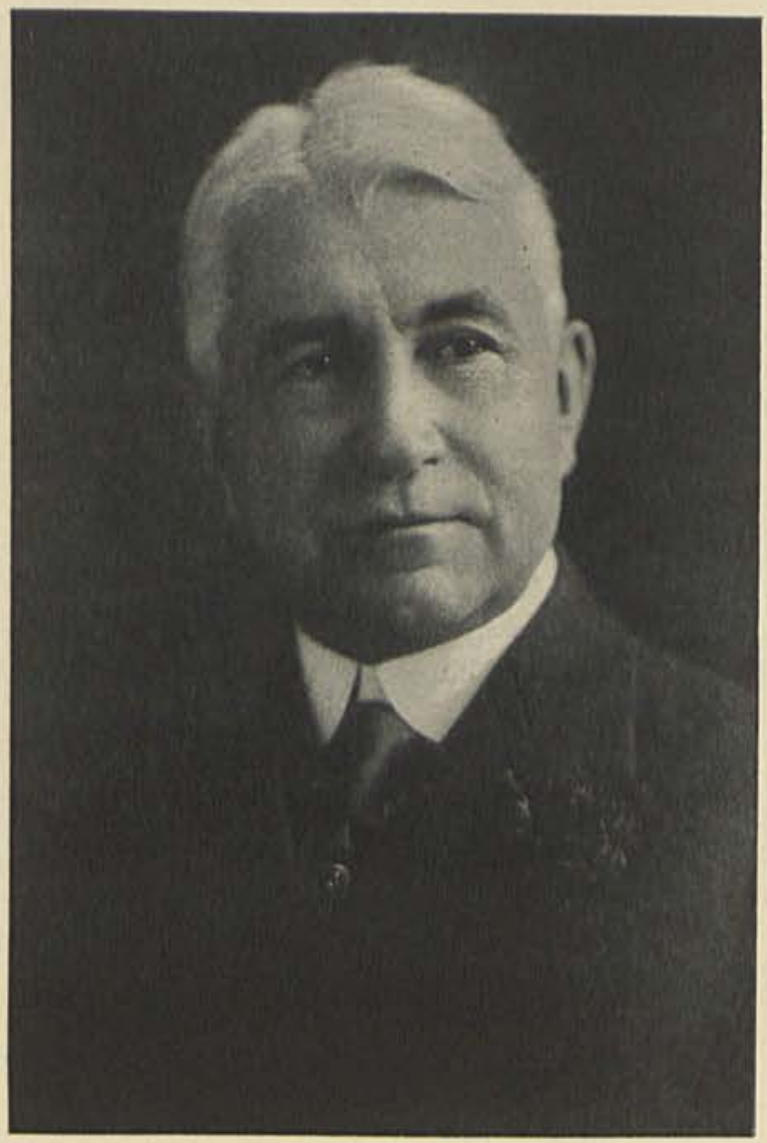

DEDICATION

to

\section{WILLIAM J.ALFORD}

$\tau \mathrm{O}$ the man who has a whole souled interest in 1 the work of this College, a faith in its future, and who has supported us so loyally, we dedicate this volume of the Cedrus. 


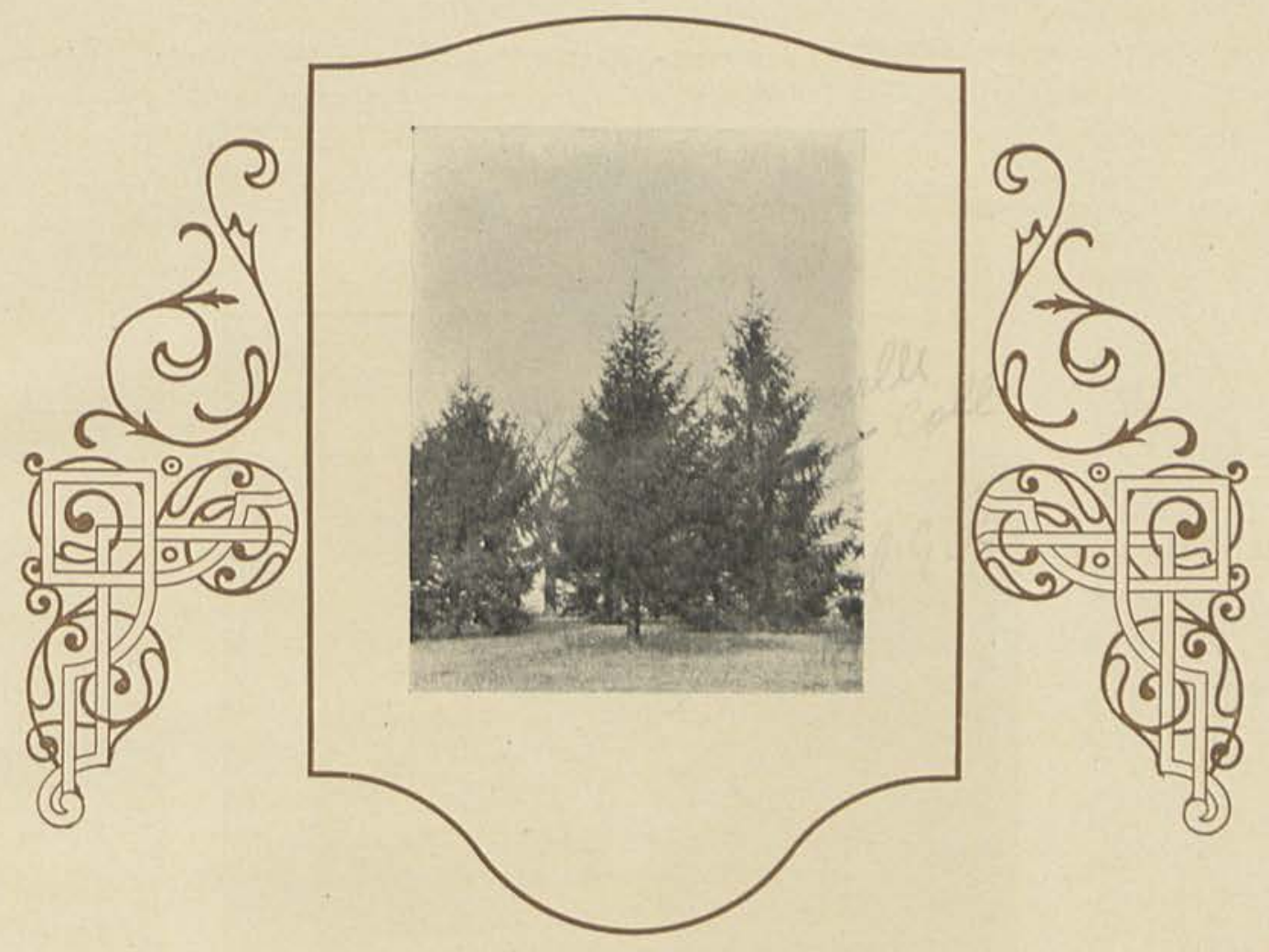

The cedar trees for which our College, our Cedrus and our town are named, and many of which help to beautify our campus 


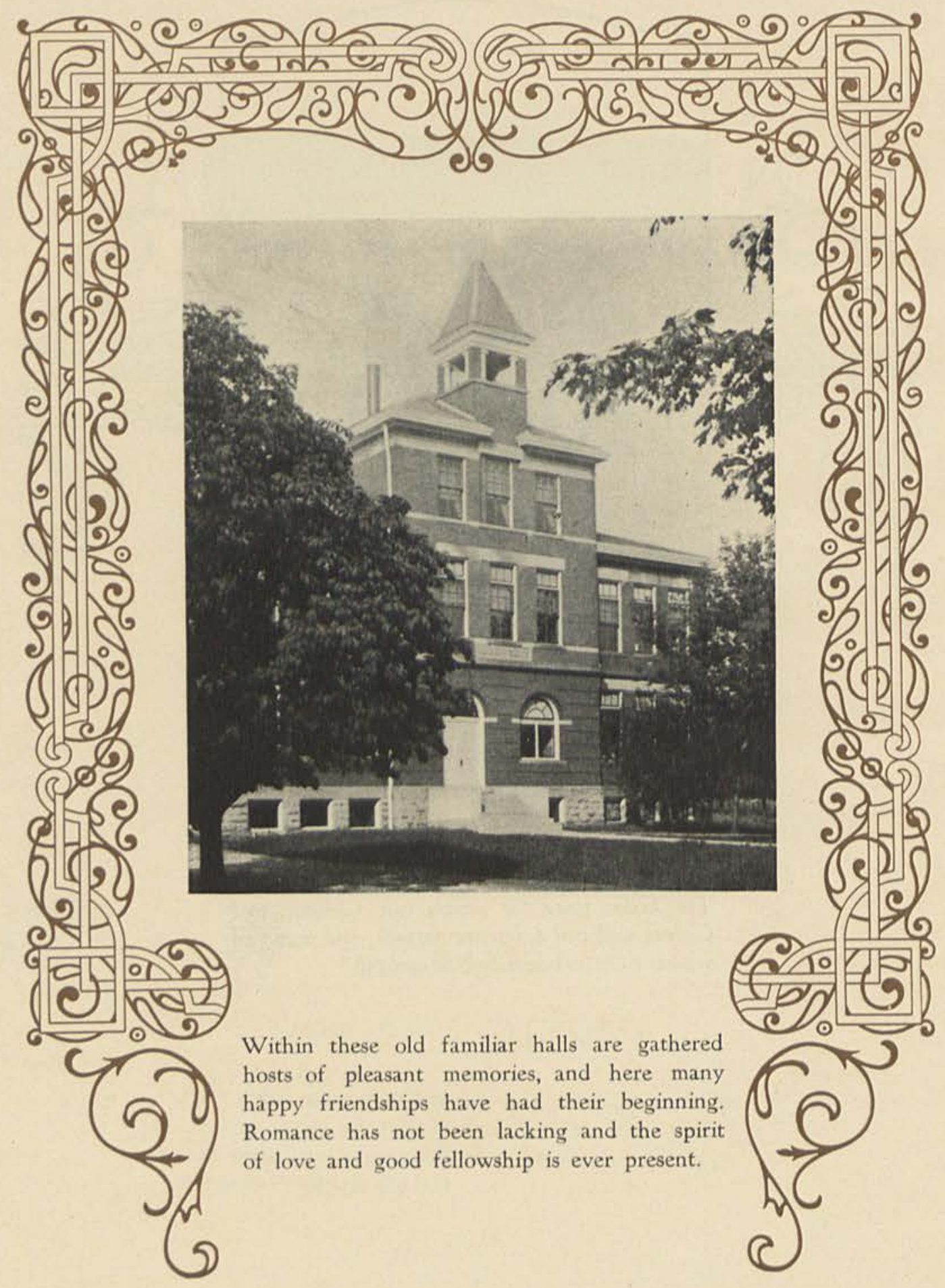




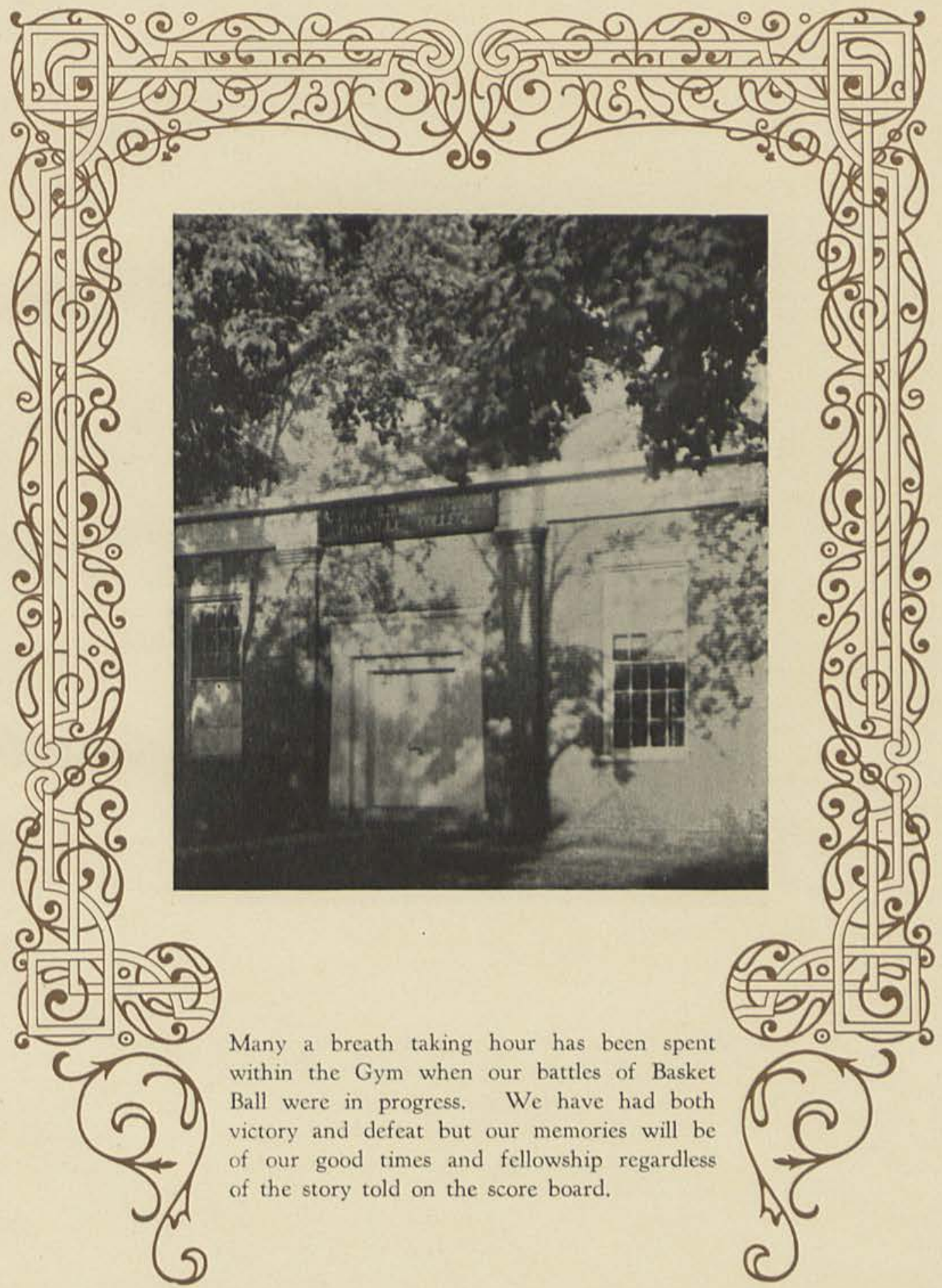




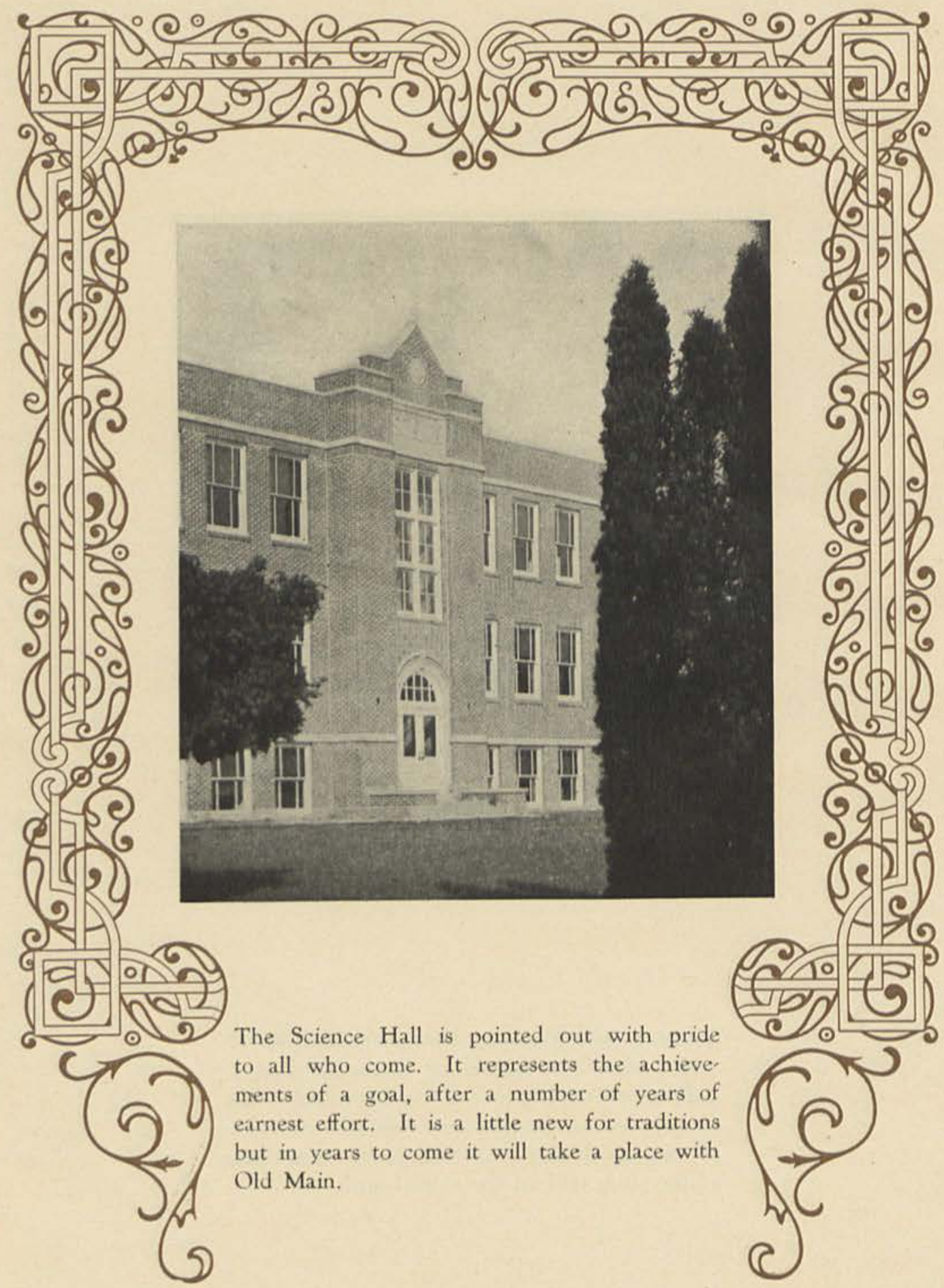




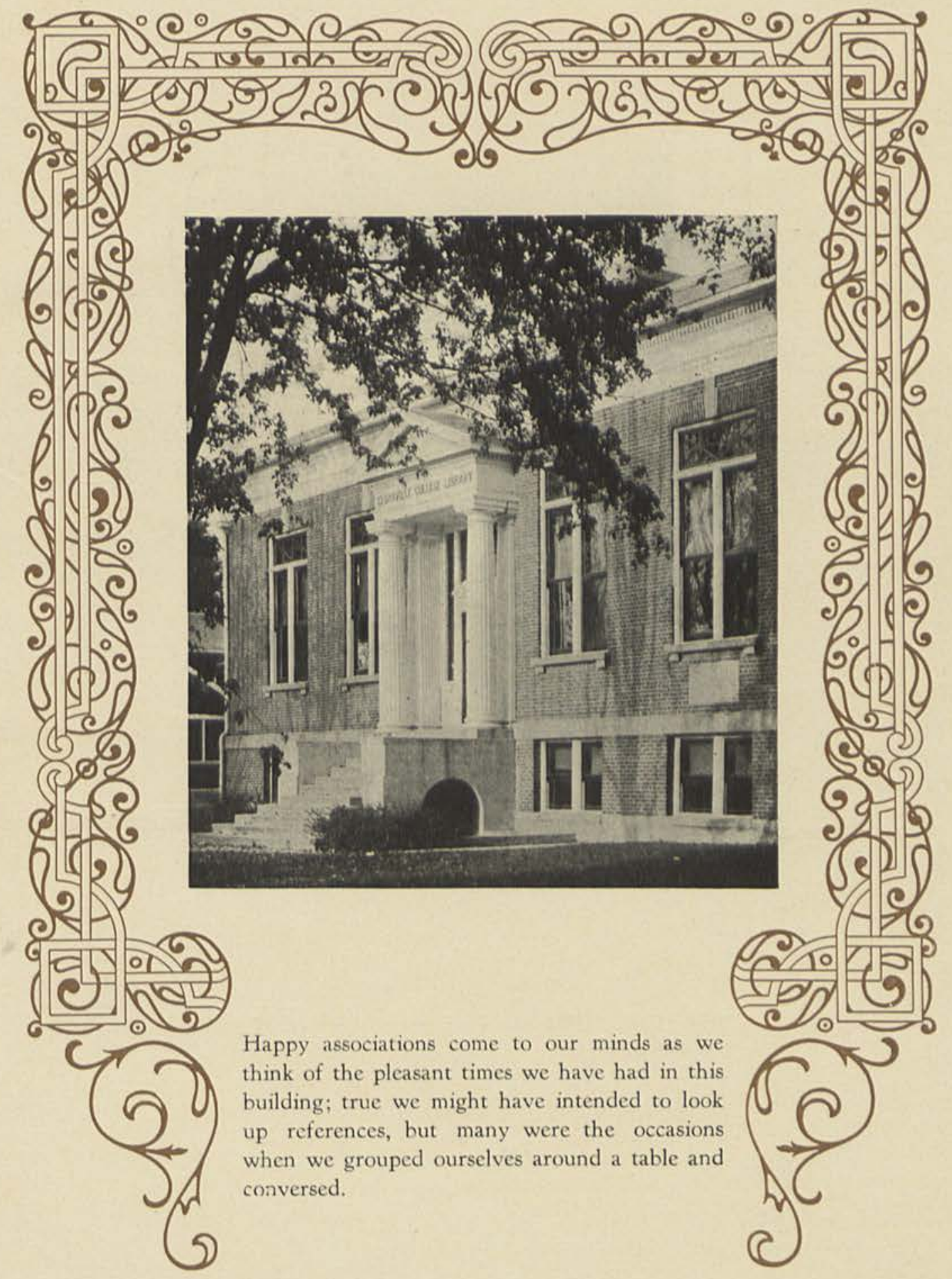




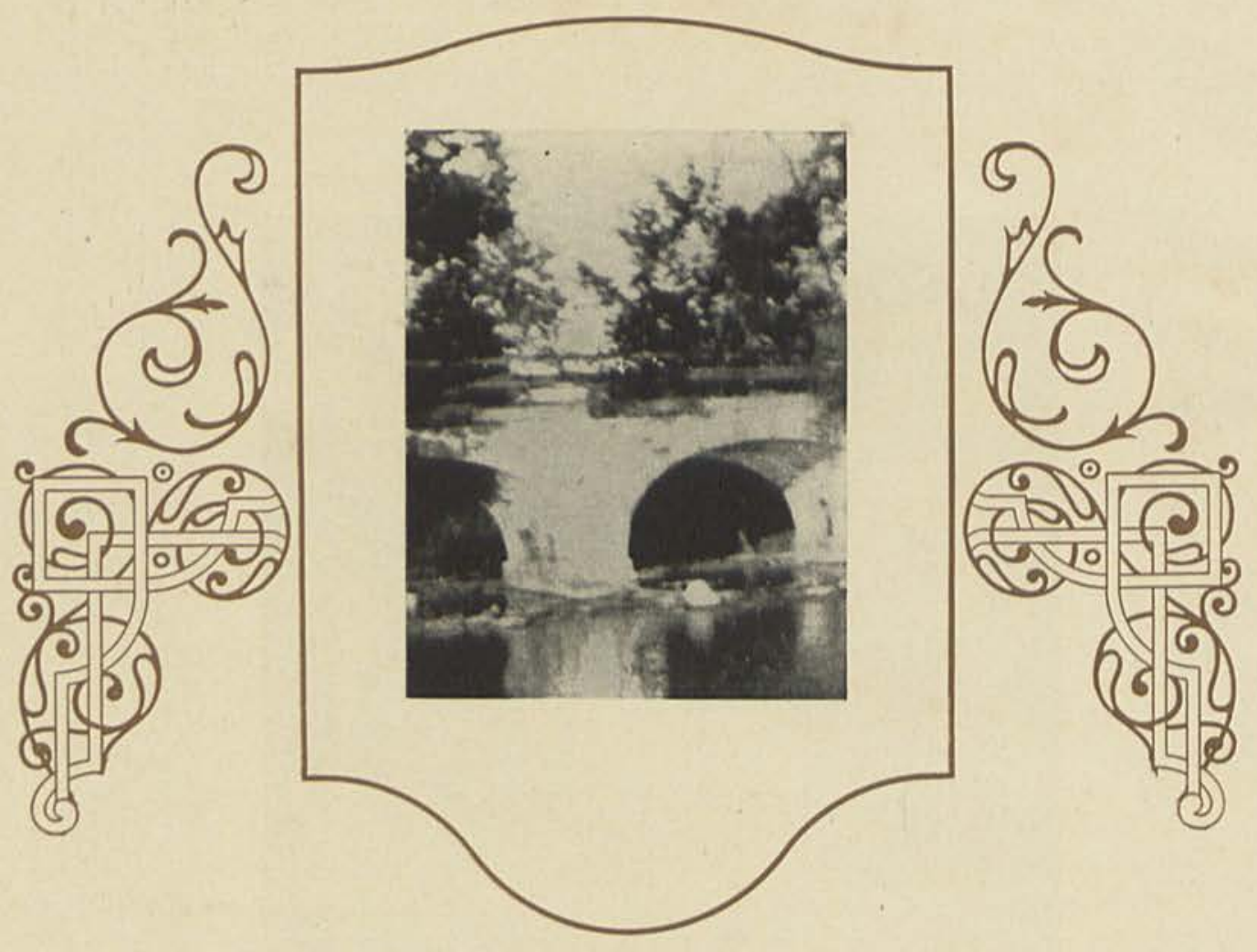

The old bridge has been the goal of many strollers on sunshiny afternoons. It is a pleasant spot to reach. 


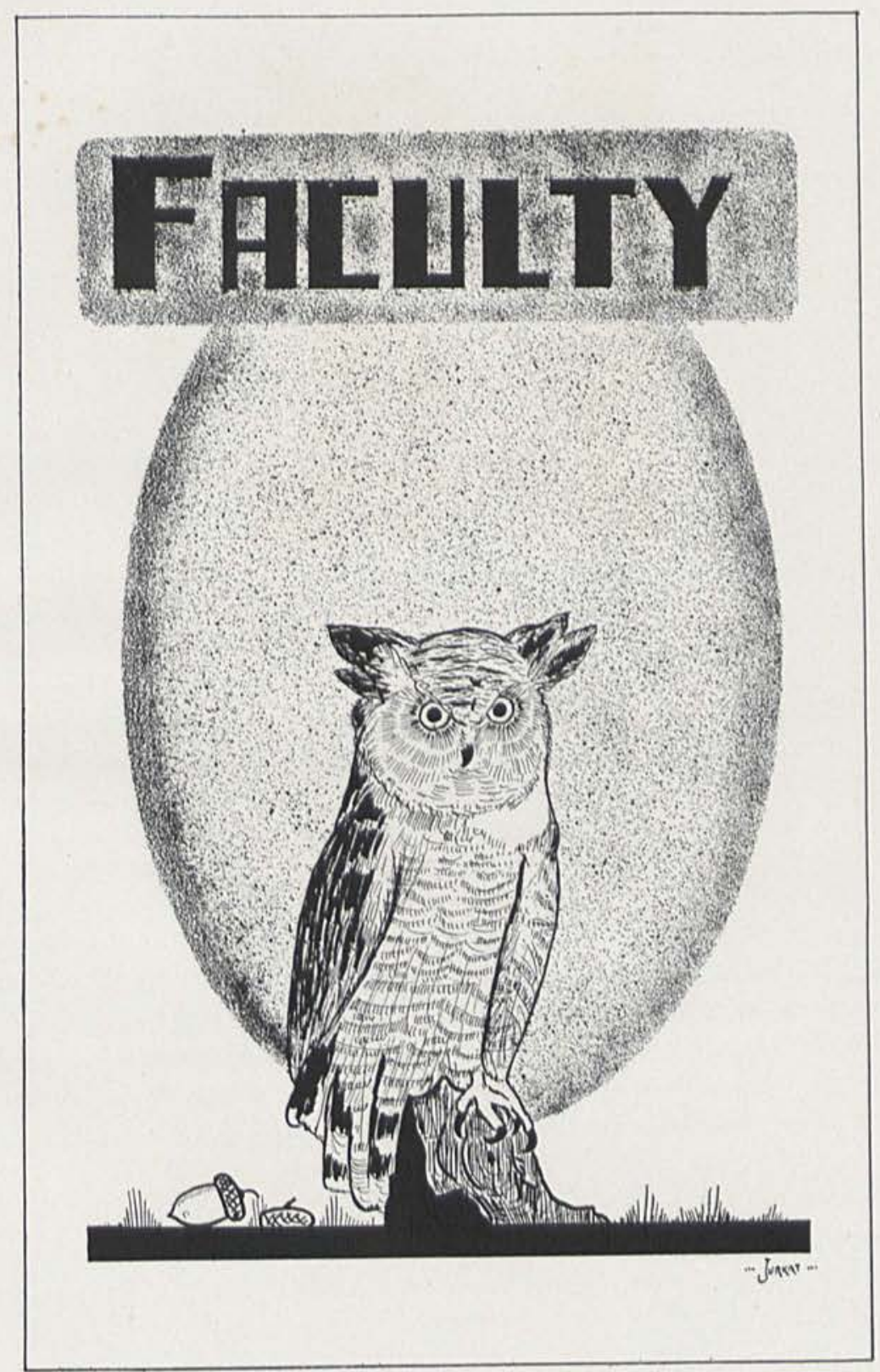


The CEDRUS 1924

\section{The Faculty-An Appreciation}

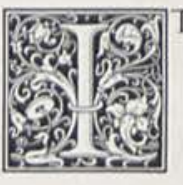

T IS AN OLD SAYING, "that a prophet is not without honor save in his own country," - yet this statement requires an exception in order that the rule may be accepted as proven. We have living exceptions to the rule in the Facuity of Cedarville College. There is probably no profession that is less appreciated by society at large than the teaching profession. Nor is there any profession that requires greater understanding of heman nature, and especially of the problems of youth, than that of the teacher.

Next to the home, there is no institution which has a greater effect and greater responsibility upon the moulding of character, and the complete developement of the individual, into an upright, self-supporting, law-abiding citizen, than the school and college. Yet it is the nature of youth to resent any form of discipline, in which the immediate ends are not seen. Often the most vivid recollections of youth are of the time when we were able to "put it over" on the professor. We fail to call to mind the times when sympathy, understanding and aid were extended to us by the same professor. It is usually not until years afterward that we fully appreciate their aid. But that is youth-impulsive, forgetful, unappreciative youth.

The faculty of a college have an especially heavy responsibility in the guid. ing of youth at the period when decisions in the selection of careers are being made. It is in this way that the faculty of a small college renders its greatest service to society. In addition it renders greater service to its small classes than those of large er institutions. Mere "hearers" of classes are to be found almost any place, but it would be a rare thing to find another such sympathetic, helpful and understanding group of professors as we have in Cedarville College. It is our hope that through these pages we may express our appreciation of the Faculty, which is headed by a man known far and wide for his kindness, helpfulness and devotion to Cedarville College and its Student Body, Dr. McChesney.

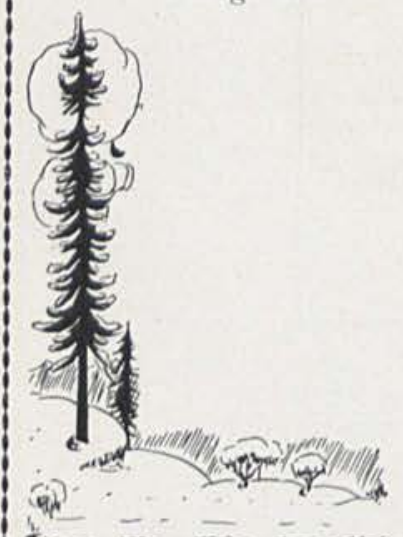

G. L.

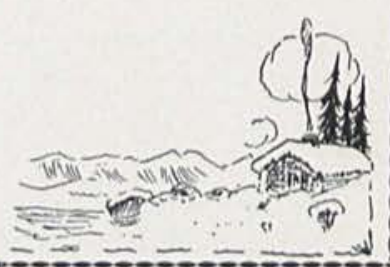


The CEDRUS 1924

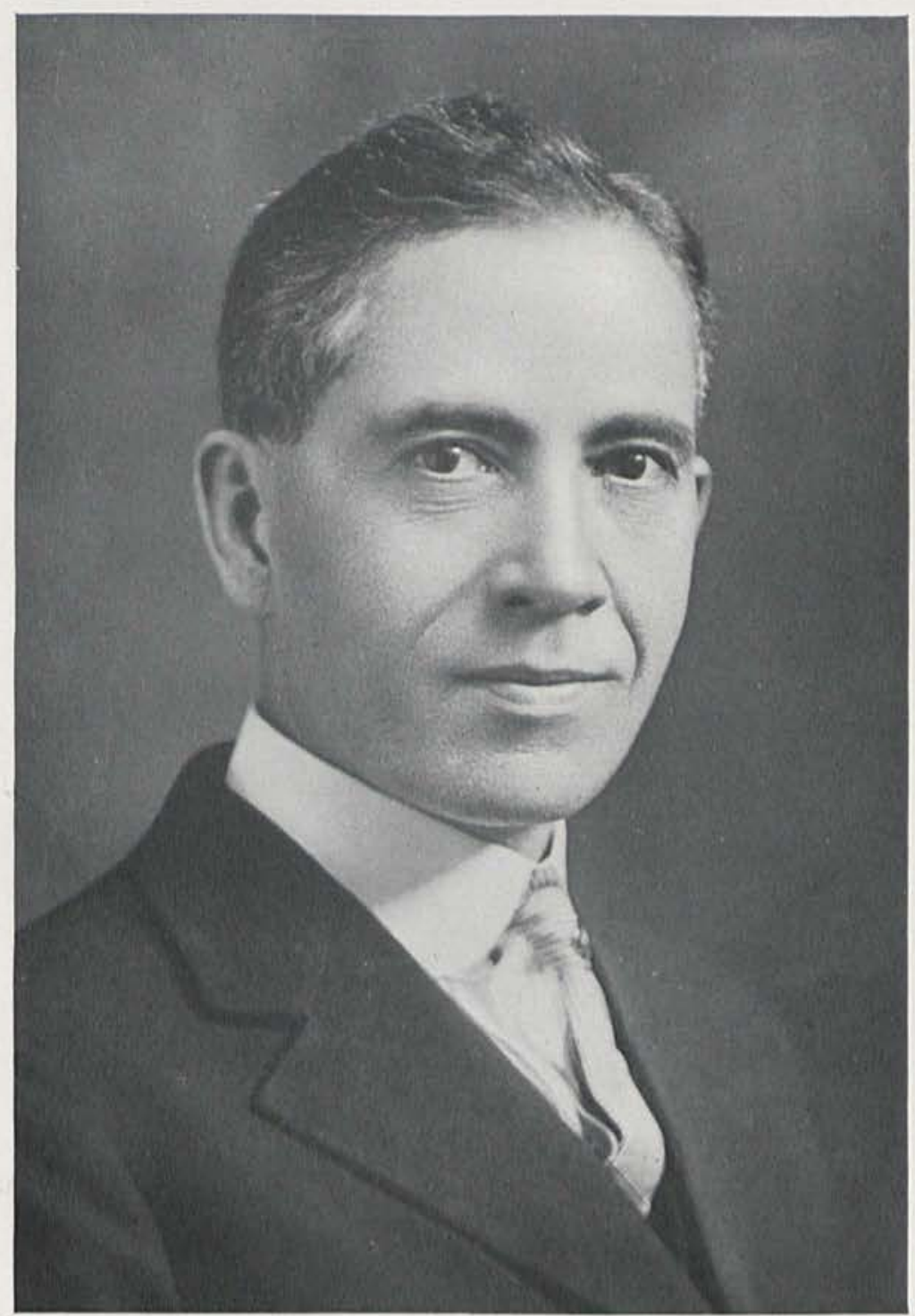

W. Renwick McChesney, Ph. D., D. D. PRESIDENT
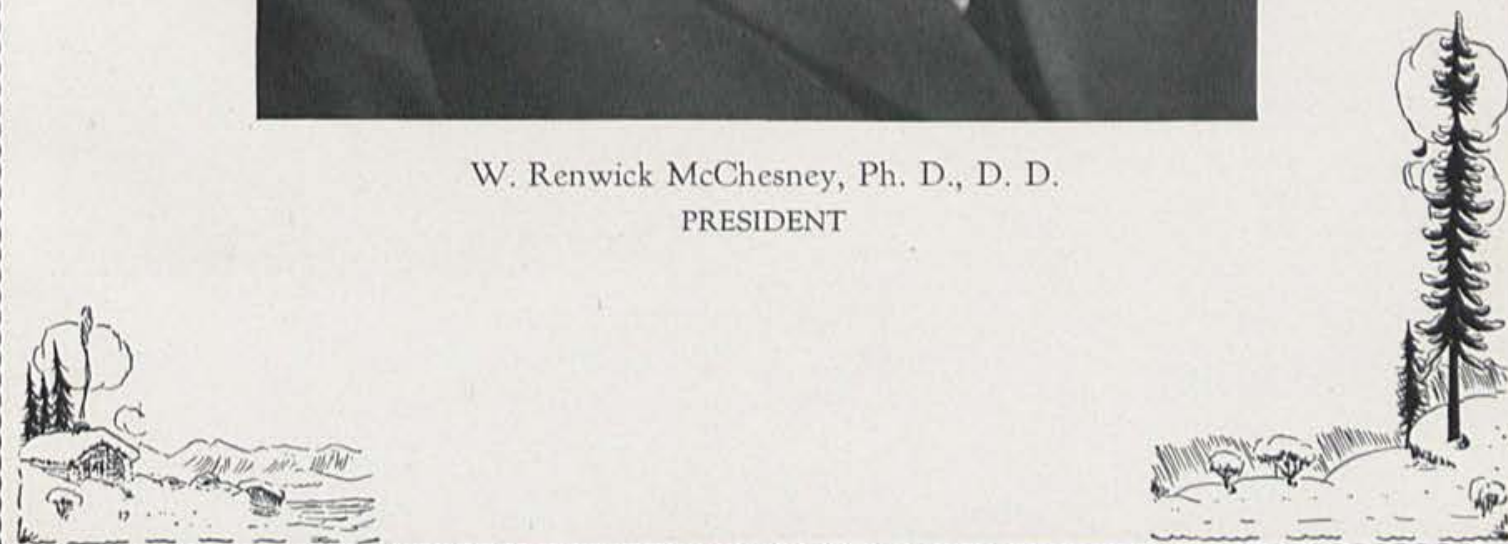

4.

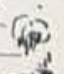


The CEDRUS 1924

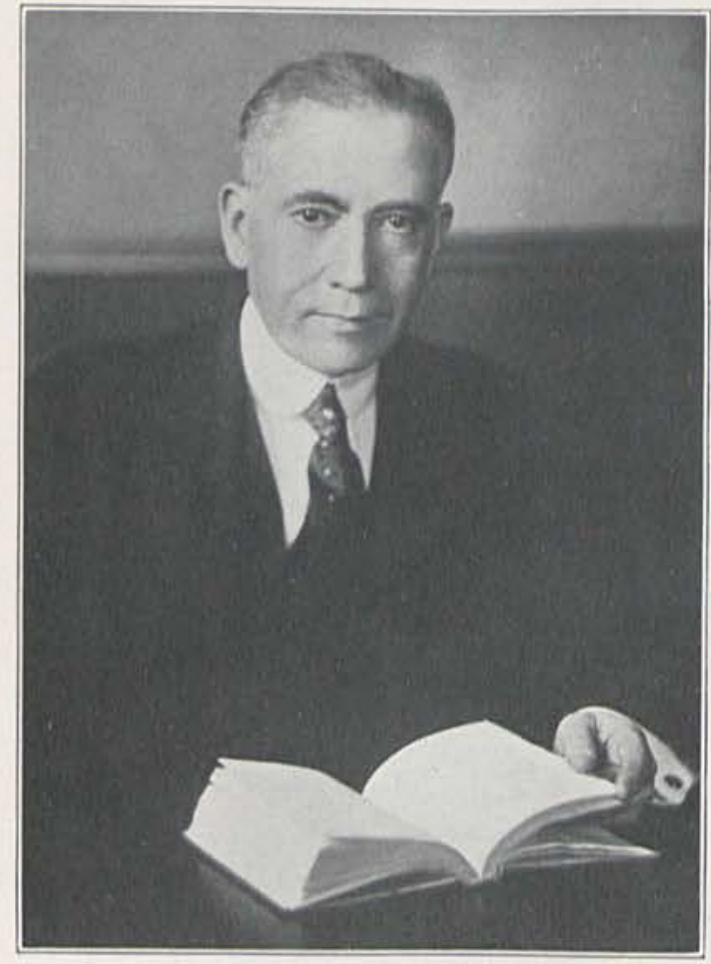

W. RENWICK McCHESNEY

President

Professor of Psychology

Oratory, Greek, Latin

A. B., Franklin College 1892

A. M., Franklin College 1894

Ph. D., Franklin College 1906

D. D., Tarkio College 1915

B. E. ROBINSON

Dean

Professor of Economics and Sociology

A. B., University of Chicago 1904

B. D., University of Chicago 1906

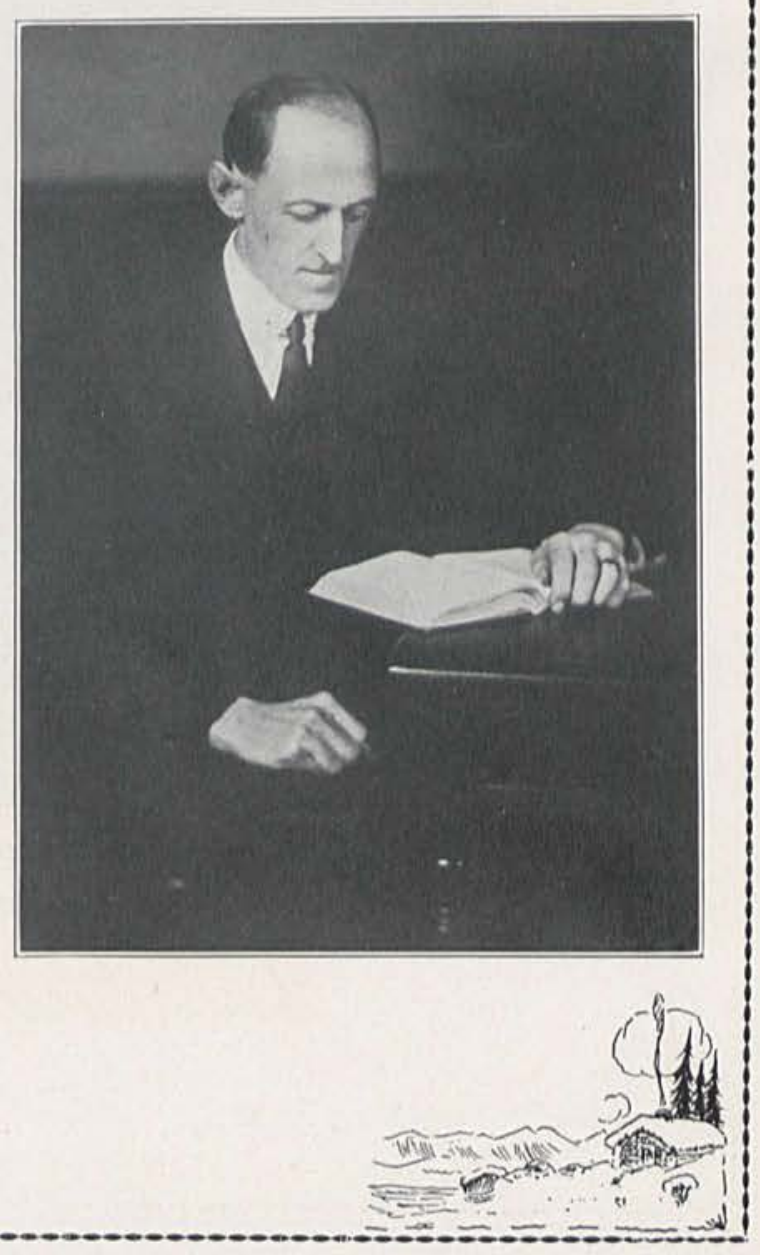

Fourtecn 


\section{The CEDRUS 1924}

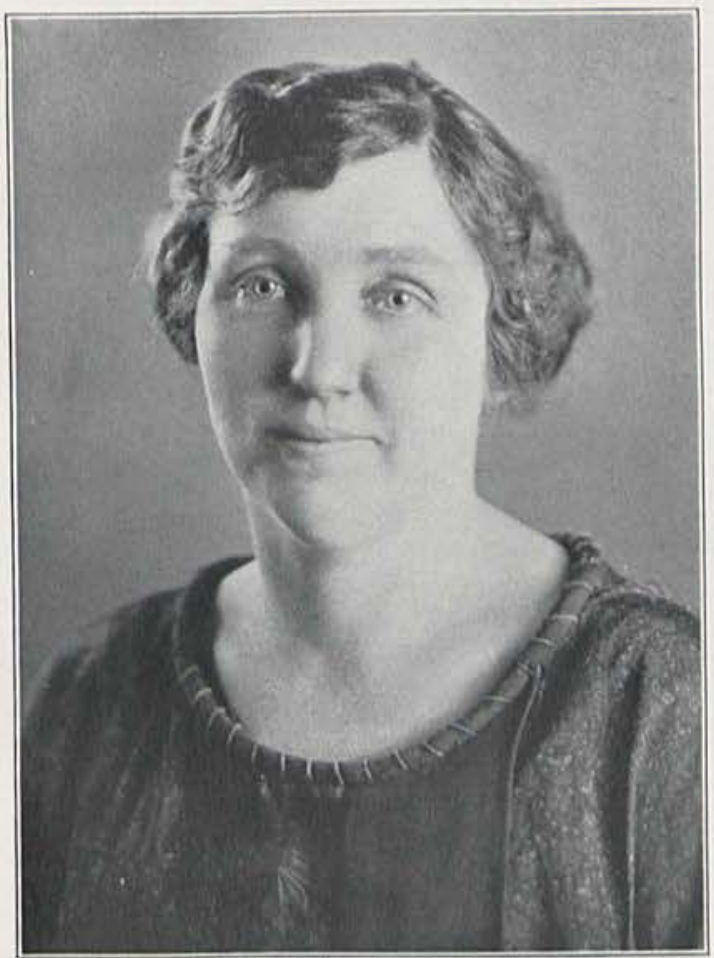

FLORENCE E. SOMERS

Dean of Women

Professor of Mathematics and Education

A. B., Cedarville 1917

FRANK A. JURKAT

Treasurer

Professor of Modern

Languages, Hebrew and History

A. B. Franklin College 1895

A. M. Franklin College 1898

LL D. Franklin College
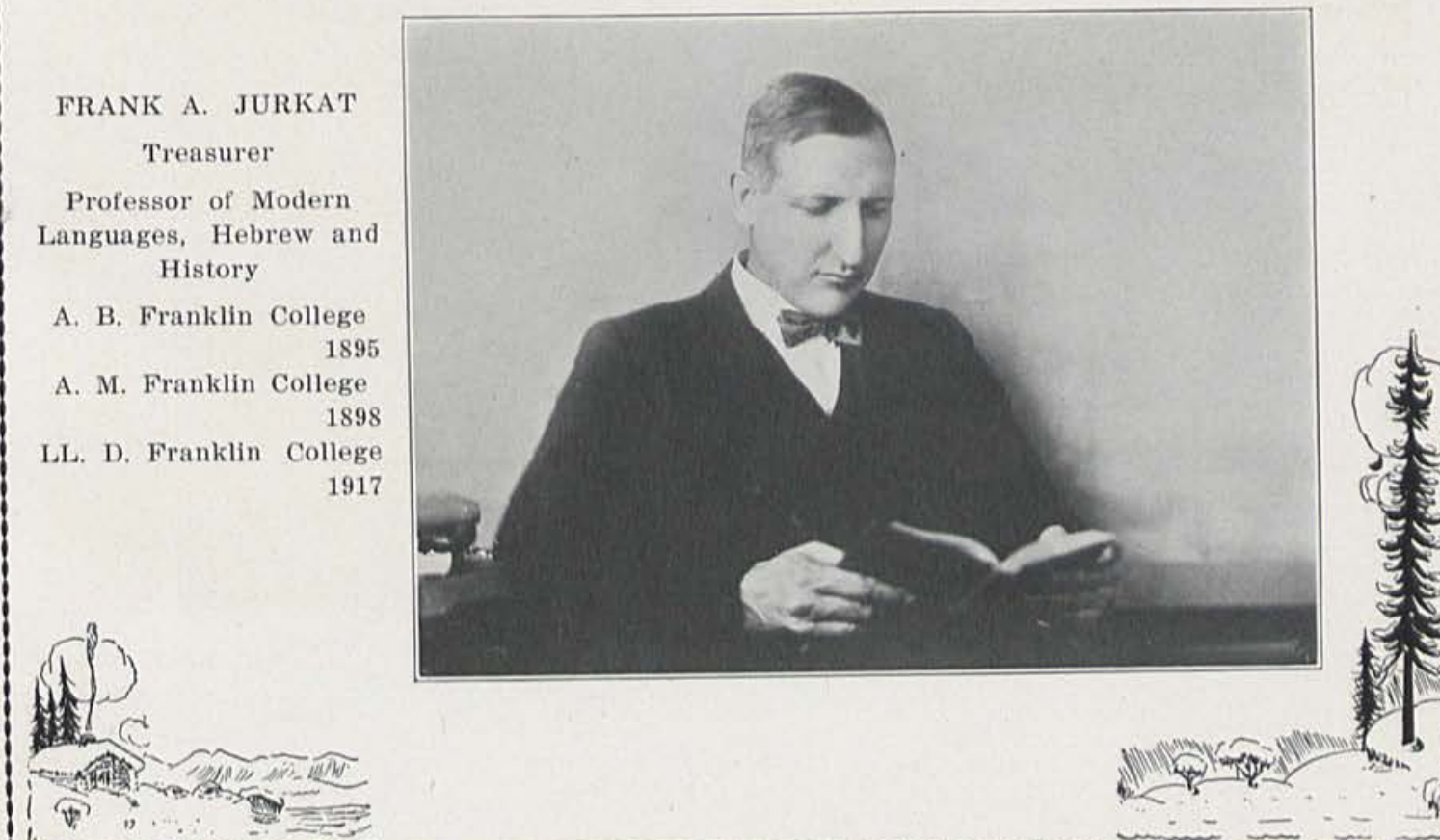

V $17, \ldots, 0$

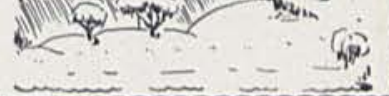

Fifteen 
The CEDRUS 1924

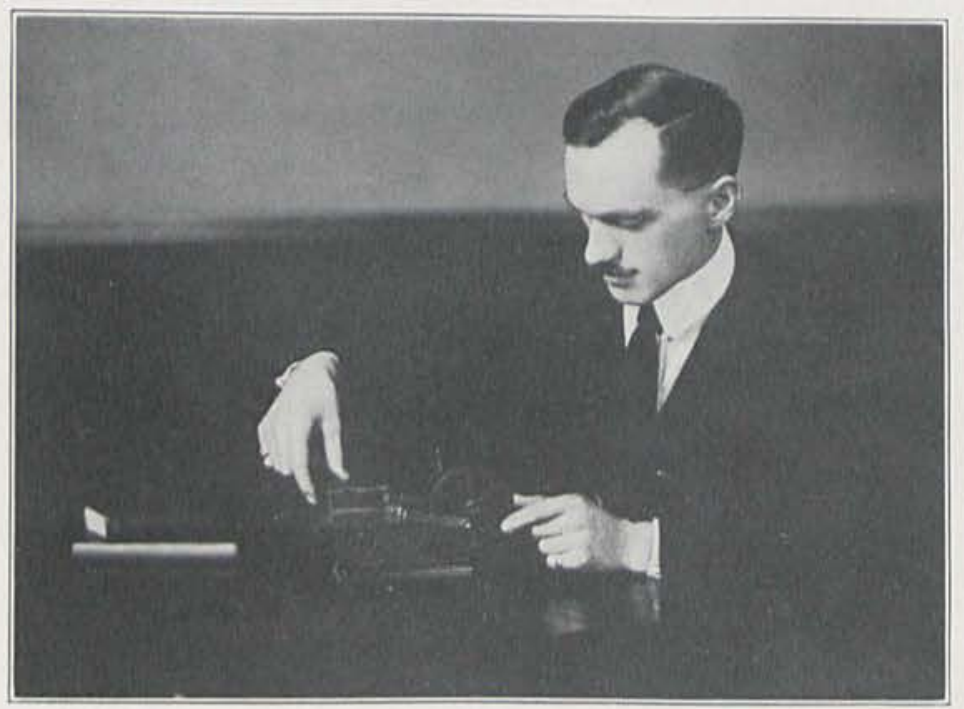

M. L. FRAZER

Professor of Science

A. B., Wittenberg 1915

A. M., Wittenberg 1922

ANNIE M. TINKER

Professor of English and French

A. B. Grove City College

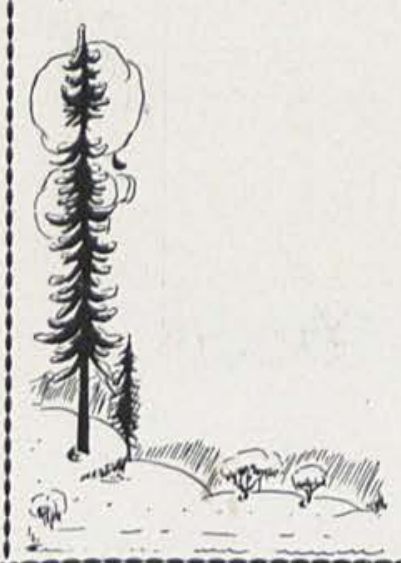

1922

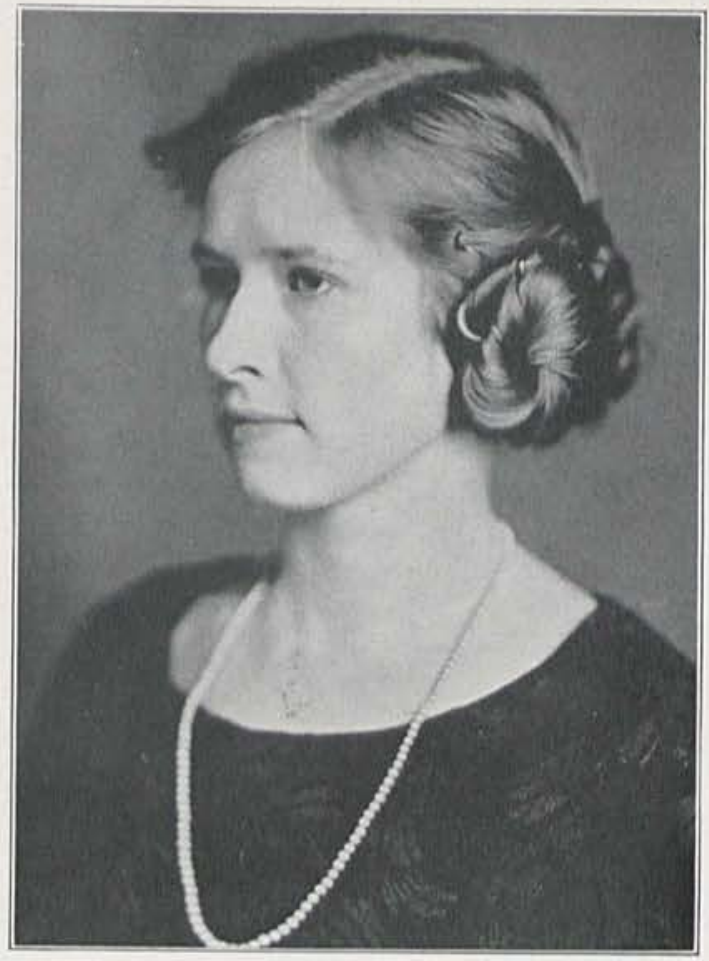




\section{The CEDRUS 1924}

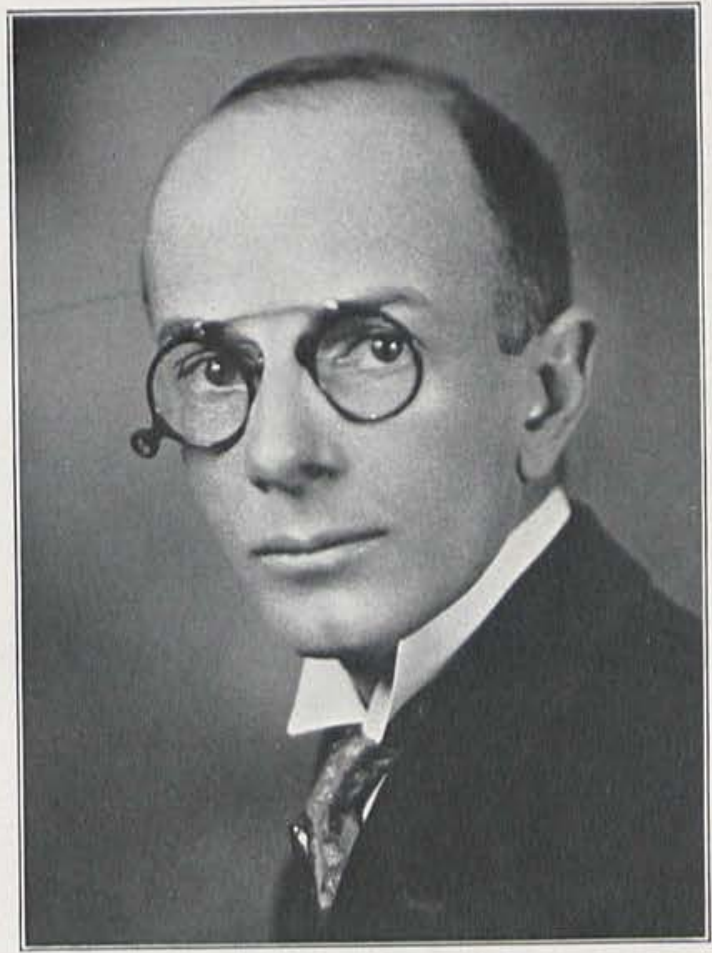

\section{JOHN ALBERT TALCOTT}

Director, Departments of Music and Athletics

Cleveland Piano School

Georgia School of Technology Royal College

SARAH J. PORTER

Registrar

Preparatory Department

B. S., Tufts College 1922
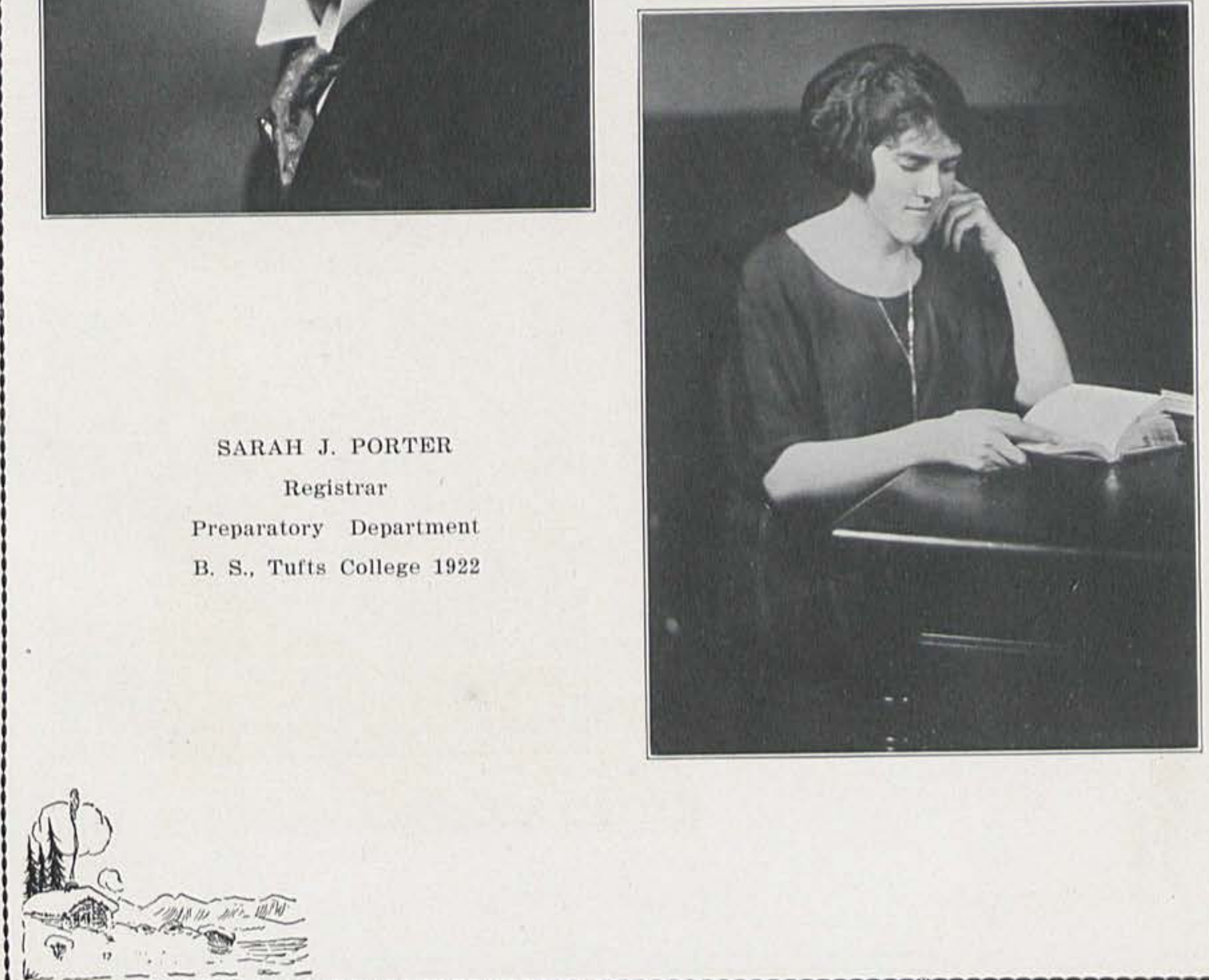

Seventeen 
The CEDRUS 1924

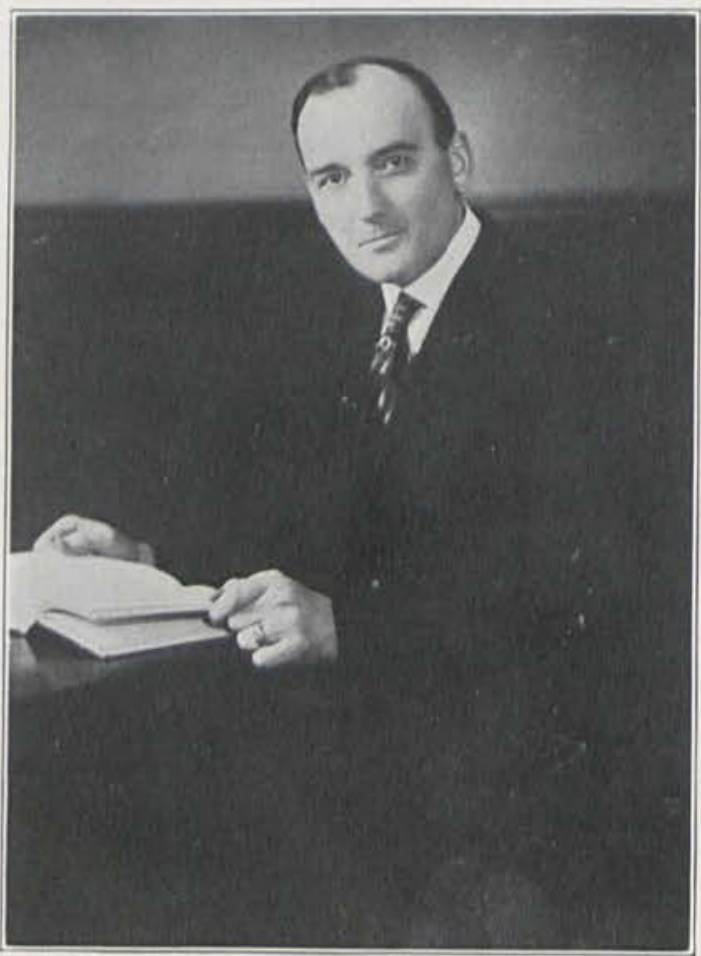

REV. W. P. HARRIMAN

Seminary

A. B., Cedarville 1912

Western Seminary Pittsburg

1915

SUSANNE M. KOEHLER

Director of Greene County Normal

A. B., B. Sc. in Ed., Ohío State University
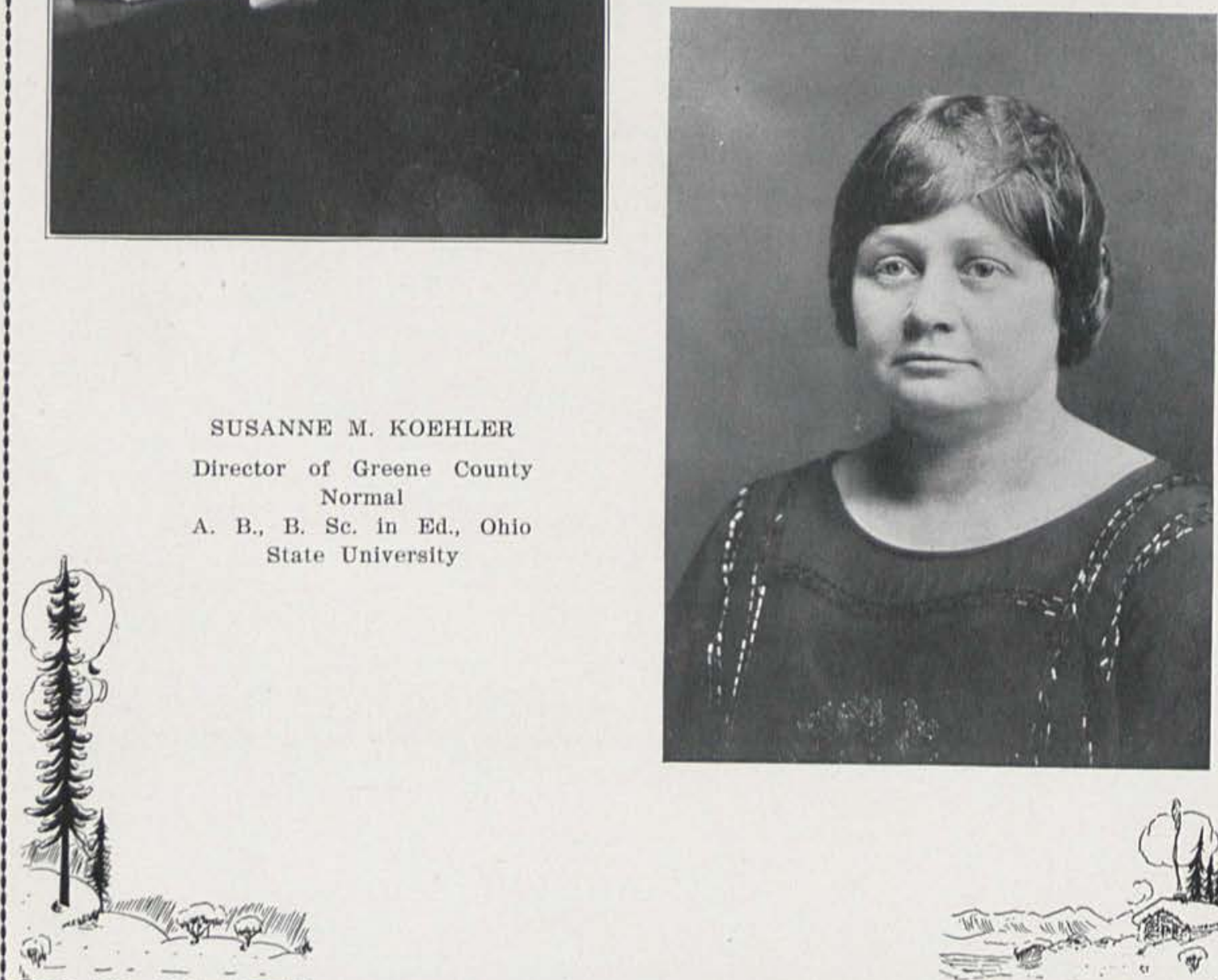
The CEDRUS 1924

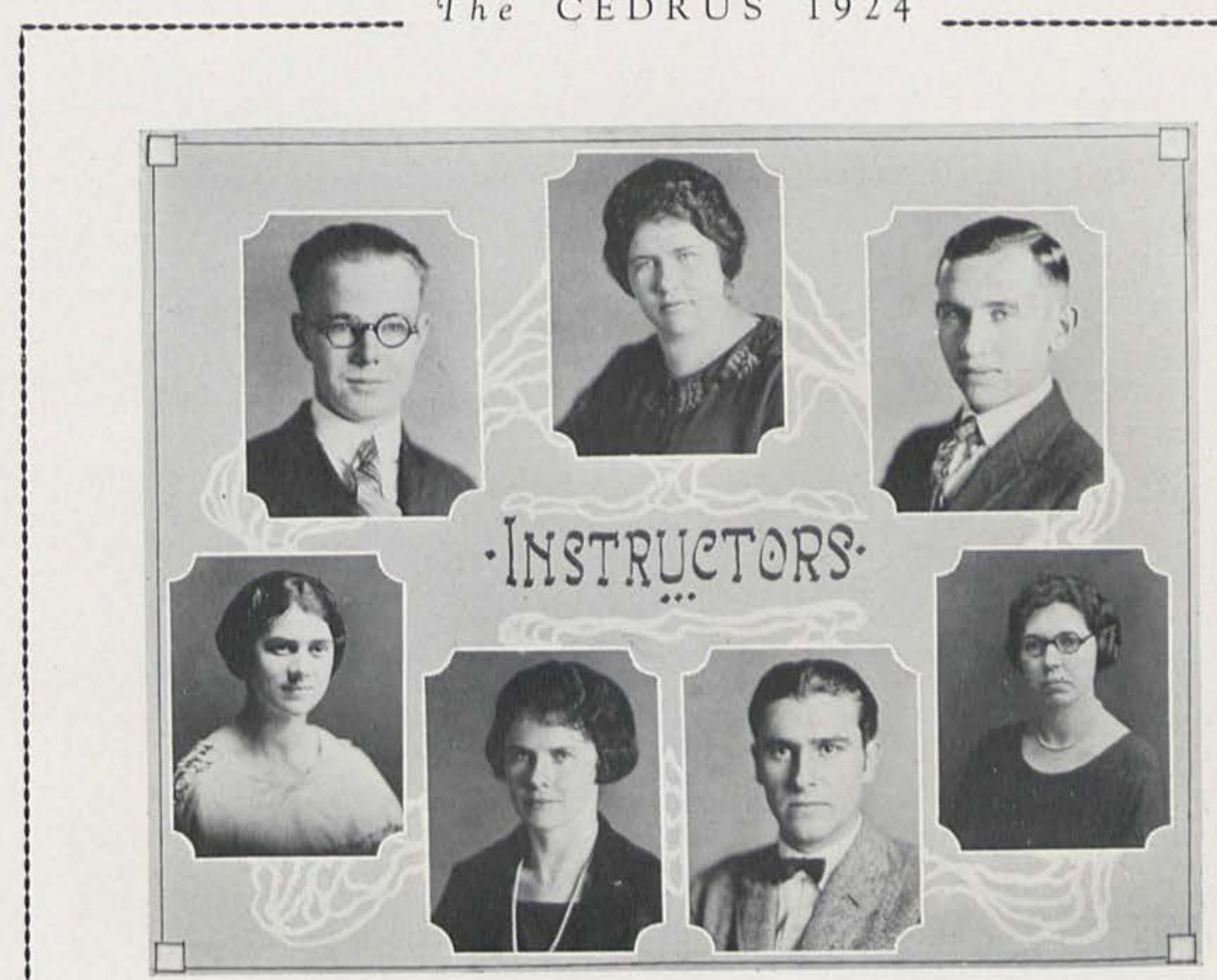

MARION STORMONT Assistant in Chemistry Instructori in Physics

HAZEL WILLIAMS

Assistant in English Instructor in General Science

THELMA DEACON Instruetor in Biology
LUCILE JOHNSON Instructor in English Instructor in Latin

LOIS ELDER
A. B. Earlham 1923
Professor of Spanish
Professor of Spanish
FORREST NAGLEY Instructor in Geometry

DONALD WICKERHAM Instructor in Geometry

LUCINDA CASKEY Ohio State University 1923 Instructor in Physiology Professor of Anatomy

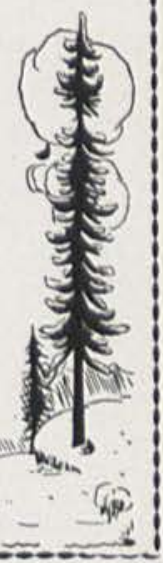


The CEDRUS 1924

\section{Faculty of Thirty Years}

THE MEETING of the General Synod of the Reformed Presbyterian Church, held in Coulterville, III. on May 18, 1894, Cedarville College was launched with Rev, David McKinney, D. D. as President. Rev. McKinney served in that capacity for twenty-one years and is now Pastor of the First Presbyterian Church of Cincinnati. During his presidency College 3.5. Hall was erected and the Alford Memorial Gymnasium, and Carnegie Library were donated. At that time the college endowment was $\$ 80,000$ but since his presidency the endowment has been increased to $\$ 140,000$, and a new Science Hall has been erected. The opening date was Sept. 19, 1894 when thirty-six students came for Instruction, in the home now occupied by C. Stuckey.

Rev. J. F. Morton, D. D. was chosen Vice President and Professor of English Bible. Rev. W. R. McChesney, D. D. was elected to the chair of Ancient Languages, and began his work for the college July 10, 1894. He served as Secretary to the Faculty, and Vice President until June 1915, when upon the resignation of Dr. McKinney, Dr. W. R, McChesney' was chosen as the new President.

The remainder of the first faculty consisted of Frank H. Dean, Professor of Science, and English; Carrie Blair, Professor of Mathematics; and Belle Beazell, Professor of Music.

Professor F. A. Jurkat came the next year, serving as Professor, Ass't. Treasurer, and Treasurer, and has remained with the college for the full twenty-nine years.

Cedarville College has always been noted for its exceptional English teachers, although some of them have only stayed a short time. The various English Professors included Frank Dean, Charles Schenck, Edith Morris, Mary Erwin, D. C. Campbell, Mrs. Llewellyn (nee Eleanor Holliday), Miss Eddy, Mrs. Leigh Alexander (Miss Ritchie), Agnes Jean Smith, Mrs. Ankeny (Margaret Schneider), Mrs, Dwight McKune (Ethel Brand), and Miss Annie Tinker.

The Science Department has been composed of the following teaching staff: Mr. J. R. Fitzpatrick, Leroy Lanning, Superintendent L. D. Parker, Millicent Hathaway, Mrs. George Blough (Katherine Flcry), and M. L. Frazer. This department often furnished the mathematics teacher also.

The various director3 of music have consisted of Belle Beazel, Mrs, Russel, Mrs. Davis (Florence Russel), Miss Emma Snow, and Professor Talcott, who has taken special training in England.

A new phase of work was installed in the College, through the medium of the Department of Education, established in 1915. As this is still the youngest department of the institution the faculty thus far has been, Judge S. C. Wright, Oscar Wesley, R. S. McIlhenny, and Miss Florence Somers.

Professor Leroy Allen, who was closely affiliated with the College from 1906 until 1922, was the first Dean, and many students who wore the Orange and Blue counted him as one of their strongest friends and closest companions. He has been ably succeeded by Professor B. E. Robison, the Dean of Men, and Miss Florence Somers, the Dean of Women.

To the many former students and alumni who read this year-book commemorating the thirtieth anniversary of Cedarville College, both fond remembrances and stirring experiences will be recalled by the mention of the above names. As we think of the Faculty of Thirty Years, our hearts go out especially to Professor Jurkat, ever a staunch pillar, and to our beloved and,honored President-Dr. W. R. McChesney, who have remained with the institution through all the trials and glorious triumphs of its history.
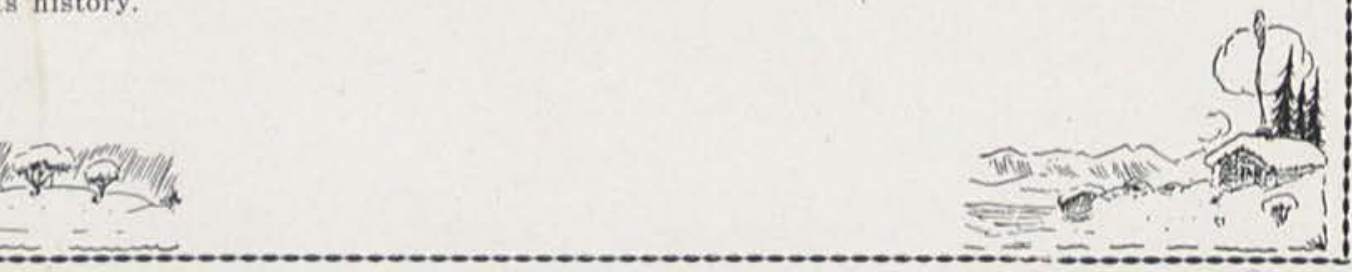

Twenty 


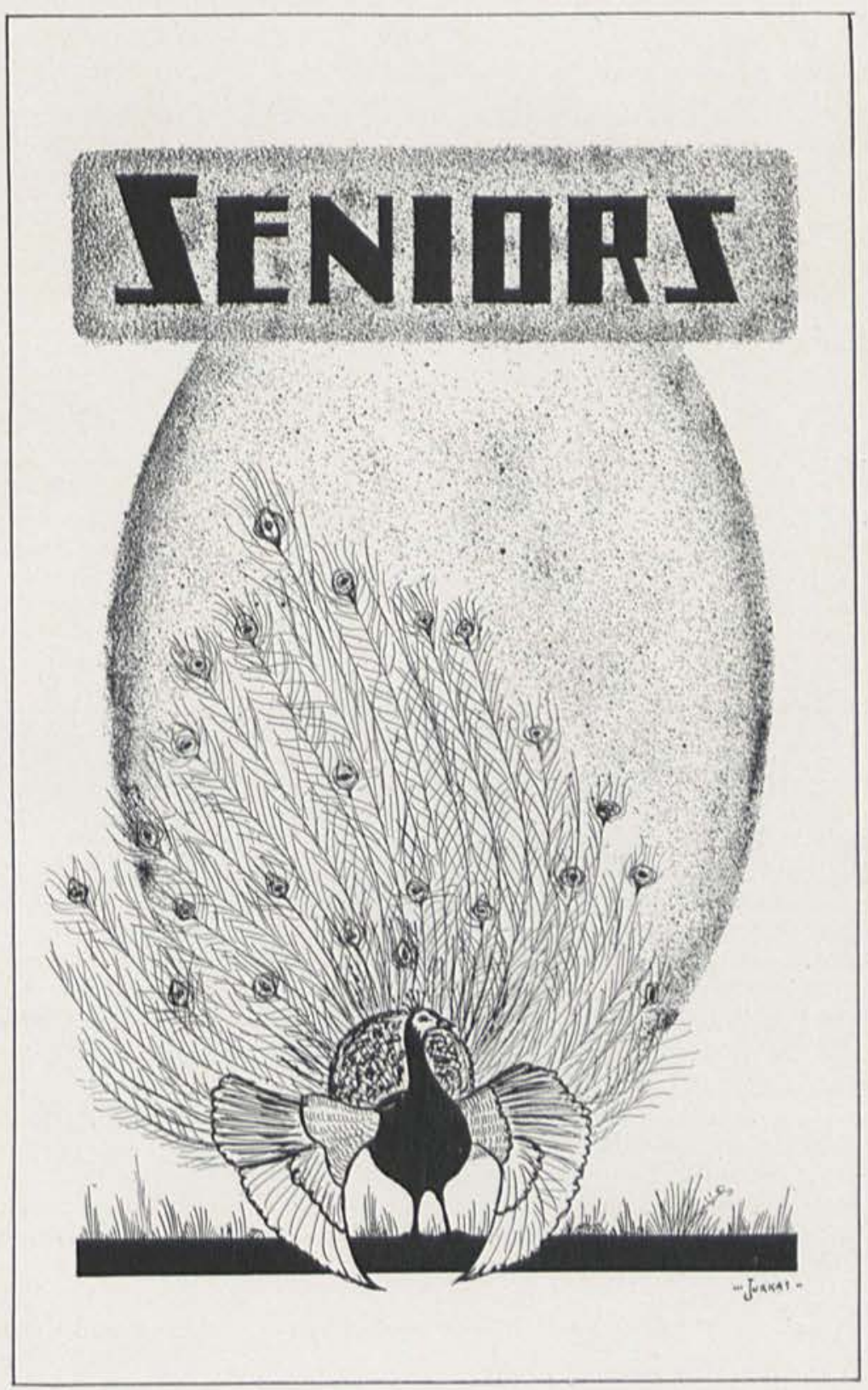




\section{The CEDRUS 1924}

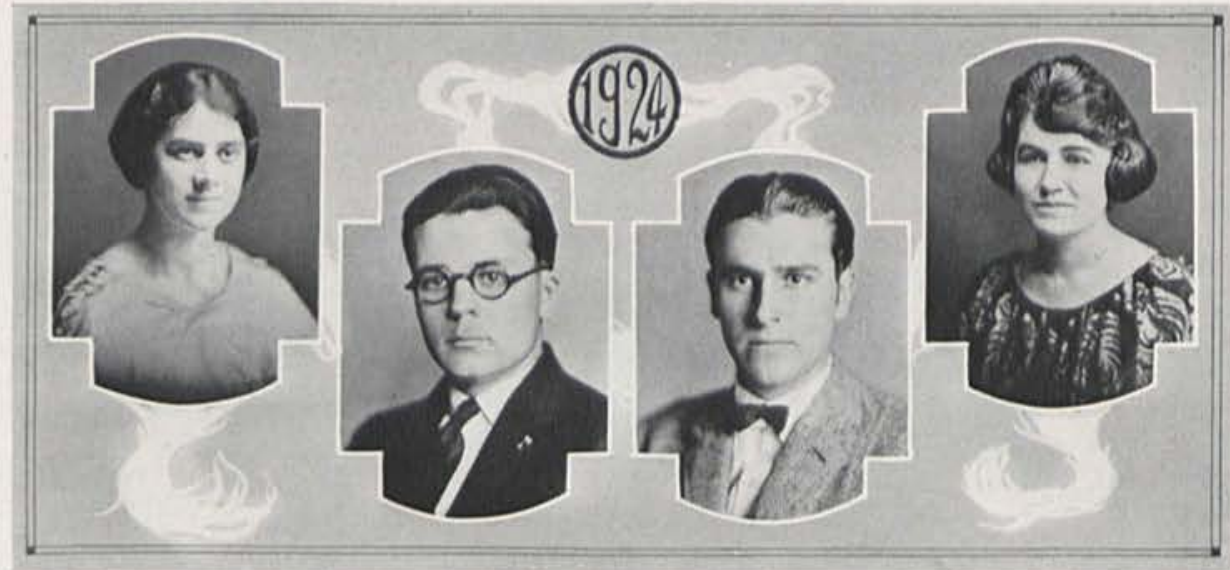

Treasurer, Hazel Williams

Secretary, Grace Lyle

Vice President, Charles Townsley

President, Donald Wickerham

\section{Senior Class History}

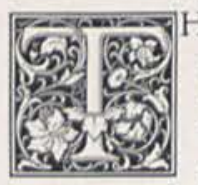

HIS IS THE YEAR of nineteen hundred and twenty-four. To many it is the same as any other year, but for one group of people, at least, it is different from all other years. This group is the Seniors of Cedarville College. After these many years in school we will leave in the spring and enter upon the next stage of our career, the school of life. All of you know the Senior Class individually. The class is not large, some fifteen members, but the quality of its members makes up for the lack of quantity. If you know the individuals you know the high scholarship standard maintained by them all.

Let us peep into the inner workings during the four "long years"-No! short years - which measure the life of the class. First we started to College, as all students should, in the year nineteen hundred and twenty. Were we good, non-green and studious? Well, we were times and not once were they broken up or any food confiscated by the upper classmen. Strange to say, we were destined to go through four years without ever losing a feed. We felt that we had a fairly successful year because of the fact that for many years every Freshman Class spread had been broken up and the feed tak-

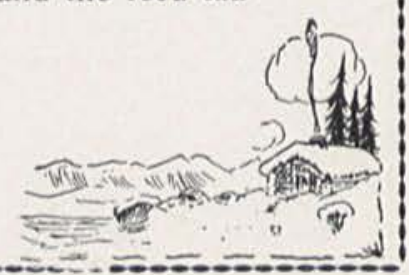

Twenty-two 


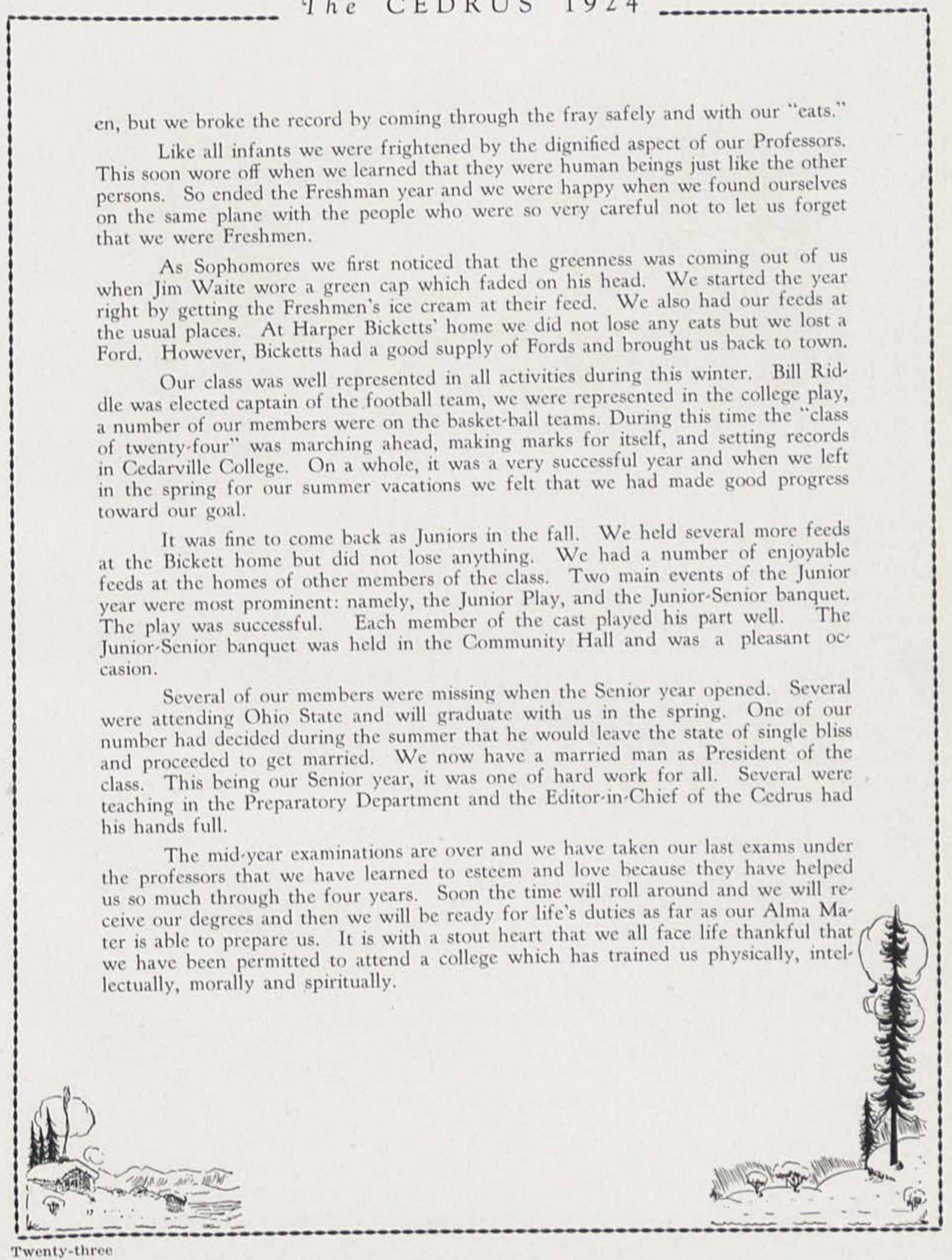




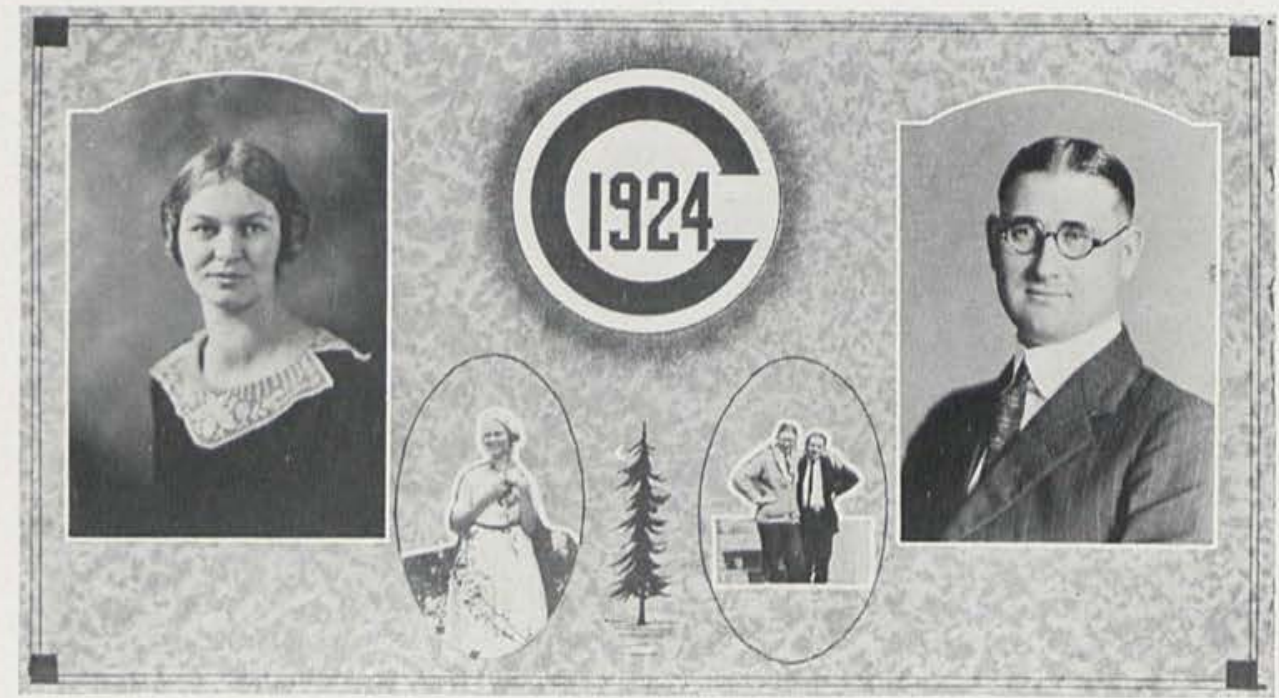

\section{CHRISTINE KYLE \\ Cedarville, Ohio. \\ Arts}

Christine

Has not let

Her College education

Interfere with her

Self-support.

And so,

Although she is not

With us this year,

This spring will find her

On the Commencement program

As a Senior.

Teaching school

Has not kept

Her from keeping up

With her work;

And, although

We strongly suspect that

She has an inclination

Towards the ministry,

We will give her

Our good wishes,

And wish her

Lots of luck.

\section{GAVIN REILLY}

Prince Edward Island, Canada

Diploma from Seminary

The Union Jack

Is Reilly's emblem,

Who inhabits

An island up in

Canada

In the

Lumber country,

And has spent

Several summers

On fishing boats;

And preaching

In Illinois;

And Overlanding

Around the country.

And soon hell

Leave us-

A clog dancer,

A husky athlete,

And an excellent preacher;

A combination

That's hard

To beat. 


\section{The CEDRUS 1924}

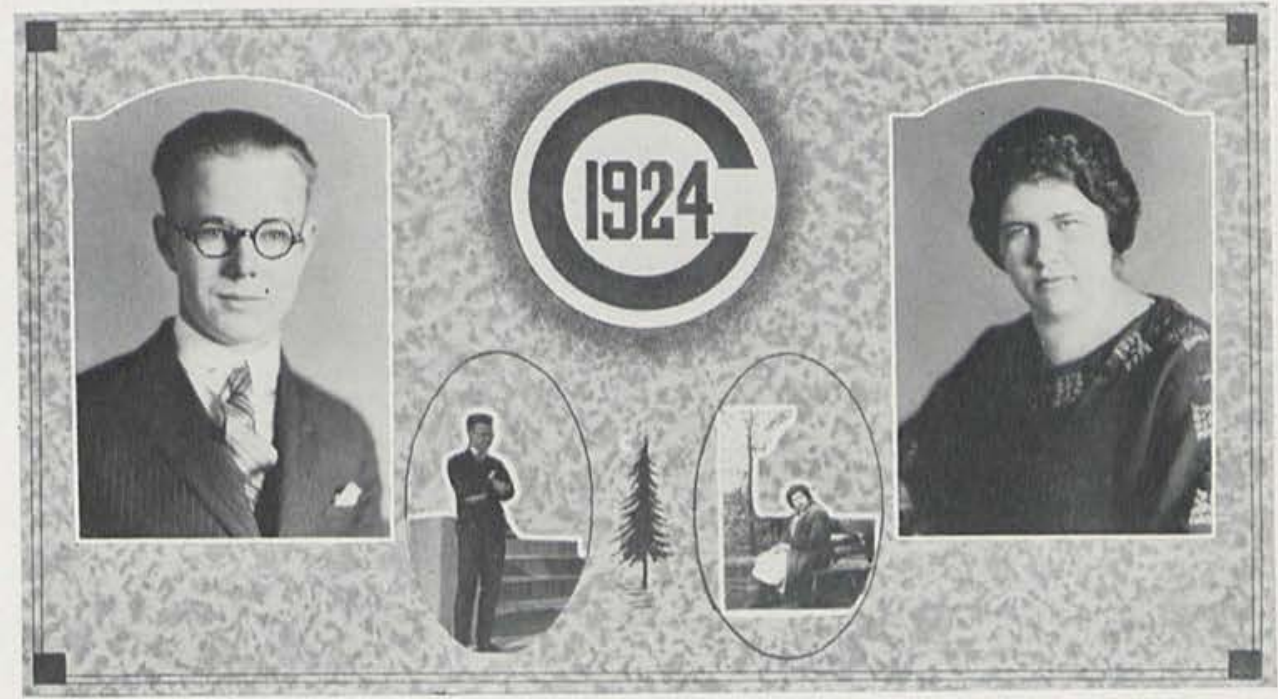

\section{MARION STORMONT \\ Cedarville, Ohio \\ Arts, Education}

Meet

Our Chem. Instructor,

The bane of

All the Freshmen,

Who spends time

And his own money on

Musical comedies

And Irving Berlin's hits

And the Sat. Eve. Post

And running down

Republican office holders.

But after all

He's really all right,

And has worked hard

(He didn't write this)

On this year-book

When he wasn't

Clerking at Doc's

Or strolling down Xenia Ave,

One of these days he'll

$\mathrm{Be}$ a surgeon,

And a good one

\section{LUCILE JOHNSON \\ Cedarville, Ohio \\ Arts, Education}

"Eat

Drink, and be merry,"

Is Lucile's motto;

And a mighty good one too,

As she shows by

Tipping the scales

At 110 -Almost.

Incidentally, she's

Received only one B

In her entire

College course;

Which shows

That the younger generation

Has not all

Degenerated

In accordance with

Public opinion;

But that once in

A while we find someone

Who can play the piano,

And study hard,

And enjoy life as well.

Selah.

Too.

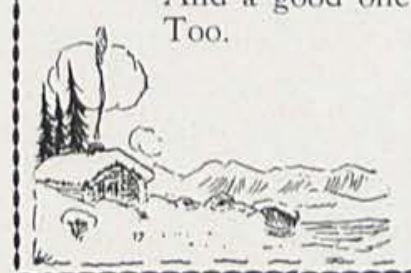

Twenty-flve 
The CEDRUS 1924

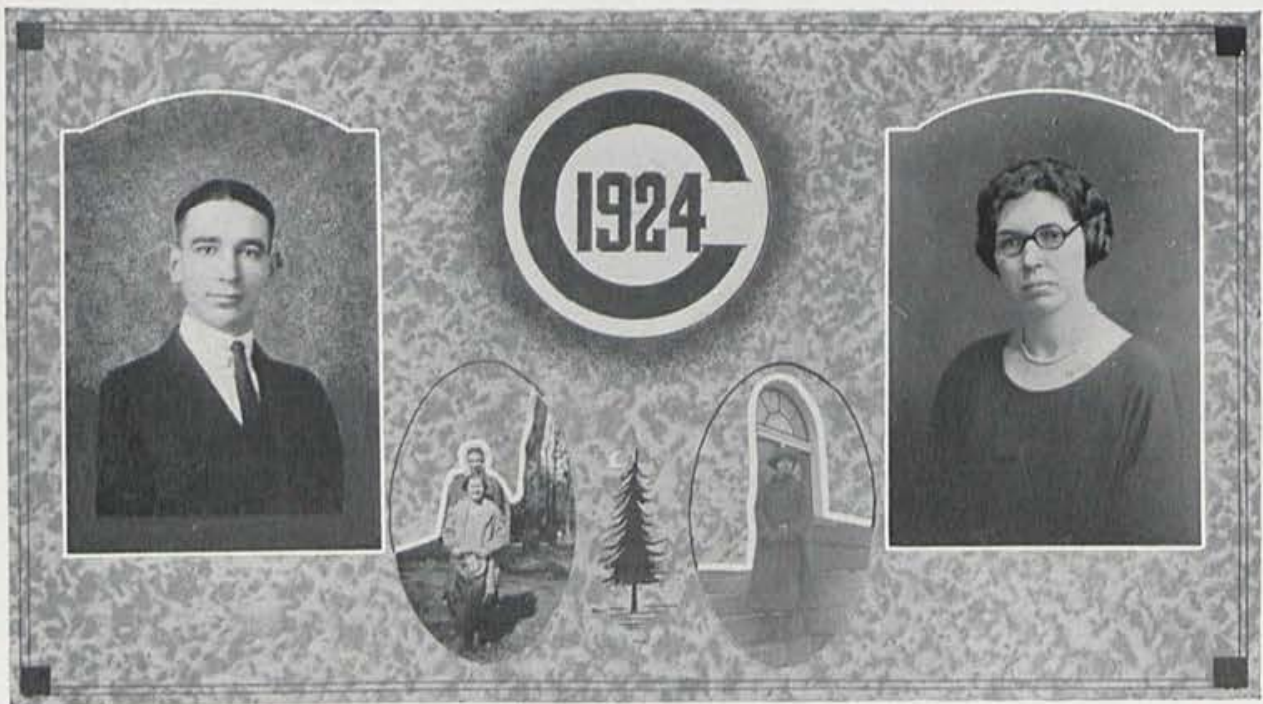

\section{HARPER BICKETT \\ Xenia, Ohio \\ Arts}

A thrifty lad,

With probably

Some Scotch blood

In him,

Who is now attending

O. S. U.

And keeping the Buckeye boys

Amused

With his subtle humor;

And meanwhile

Learning how

To become a

Finished agriculturist.

$\mathrm{He}$ will be "finished"

This year by

Graduating at C. C.,

And will then proceed

To prod Mother Earth

Into producing

More than her quota

"Down on the farm."

\section{THELMA DEACON \\ Xenia, Ohio \\ Arts, Education}

Thelma

Hails from the

County seat,

And has raised

Our opinion of it

Considerably

By getting "A's"

For many a moon;

Consequently

She is Secretary

Of the

Crown Club,

And has also

Done her bit

For this book

By helping keep

The calendar.

So she's a

Willing worker,

And we wish her

Luck

When she teaches

Next year. 
The CEDRUS 1924

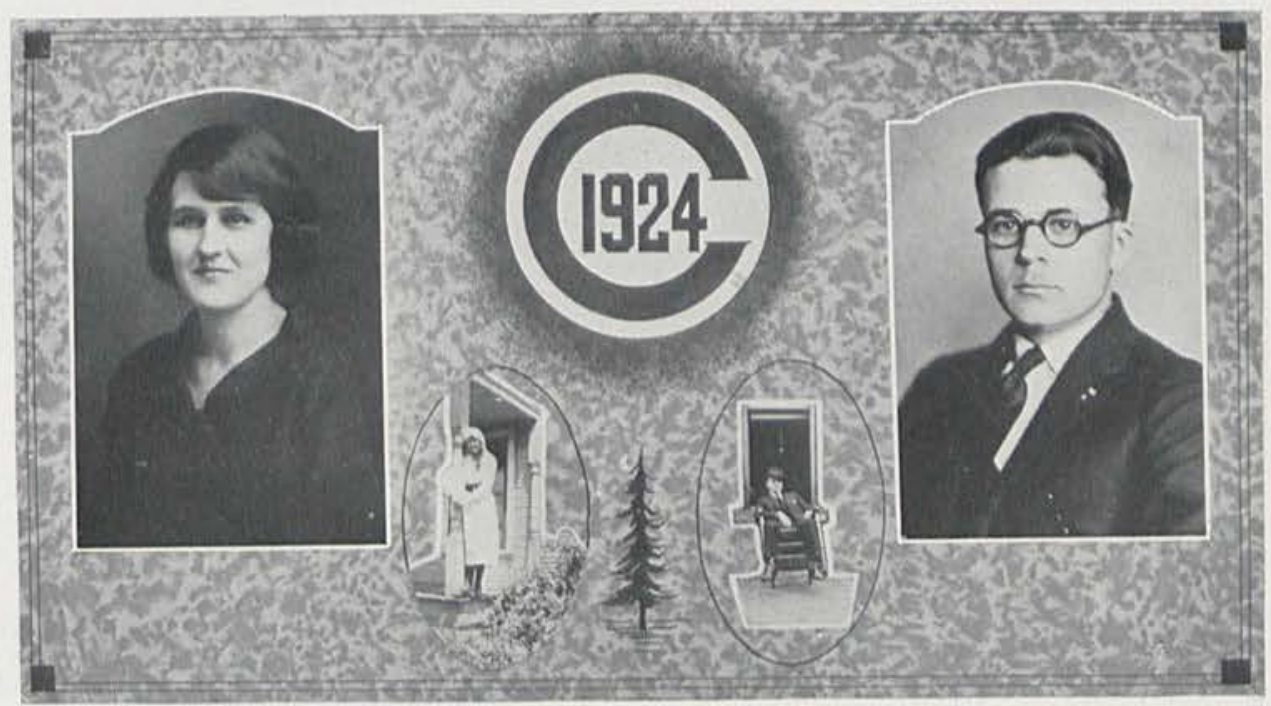

\section{LUCINDA CASKEY}

Cedarville, Ohio

Arts, Education

Lucinda

Is naturally

Afflicted

With a

Sunny disposition.

And so

She always has

A smile

For everyone;

For which

We cannot

Blame her,

But can only

Bid her

A sad farewell

As she leaves us

This spring

To bless

Some other school

With her

Kind

Nature.

\section{CHARLES TOWNSLEY}

Cedarville, Ohio

Arts

Versatility

Is the word

For Charley,

Who is a

Kodak fiend,

And a "whiz"

On the saxophone;

And was Basket Ball Mgr.,

And can bake

Bread and cakes

That will

Melt in your mouth.

He'll make someone

A good housekeeper;

And we

Suspicion

That someone

Down in Nelsonville

Is waiting

To be his

Valentine.

Lucky boy.

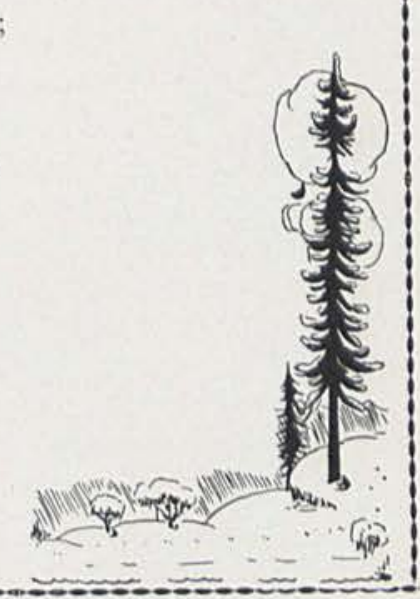


The CEDRUS 1924

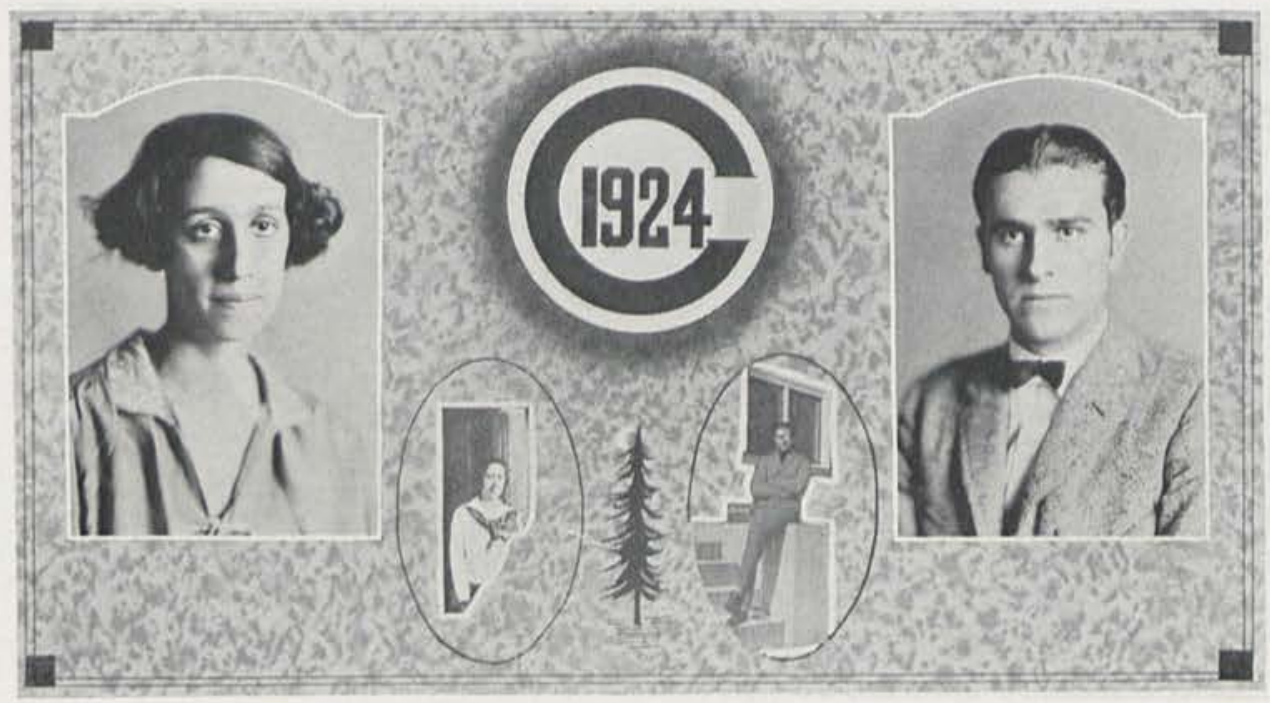

\section{NETTIE SHAW \\ Clifton, Ohio \\ Arts, Education}

Nettie

Is the latest

Of a long line

Of Shaws

Who

Have attended

This institution,

And has ably

Kept up

Their

Standard of

Scholastic accomplishments.

So we are sure

She will succeed

When she

Teaches school,

Becausc

She

Works hard

On studies

'n basketball

$n$ everything.

\section{DONALD WICKERHAM}

Springfield, Ohio

Arts, Education

About a year ago

Wick said,

"I'm tired of living alone;"

And so he

Journeyed to Springfield

And with Cupid's help

Drew a

First prize

When she murmured "yes."

So now

There are two hearts

That beat

As one.

But Donald

Has not allowed this

To interfere

With his

College education,

And will leave us

This spring

Working hard

As usual. 
The CEDRUS 1924

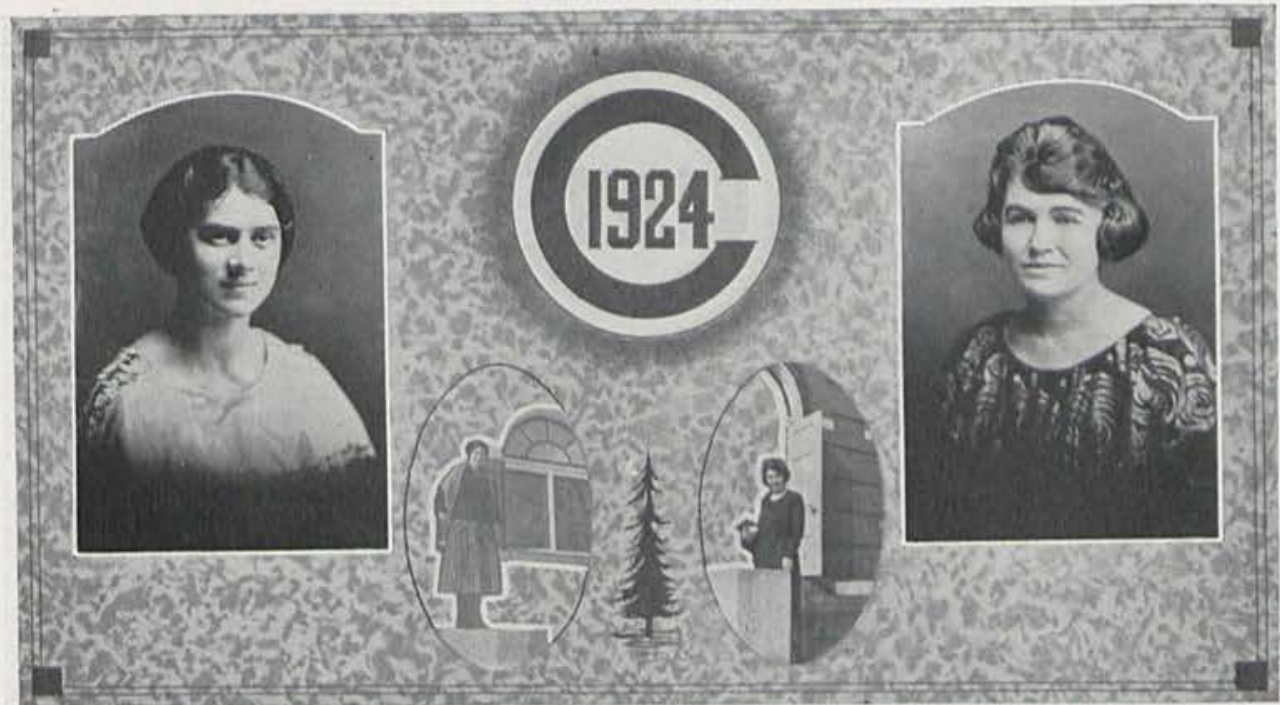

HAZEL WILLIAMS

Cedarville, Ohio

Arts, Education

Getting through College

In three years

Is some stunt

Nowadays;

But Hazel

Has performed it

With ease;

And has had,

Seemingly,

Oodles of time

Besides

To be a

Y. W. officer,

And Basket Ball Mgr.

And to work at

Chautaqua, N. Y.,

And to send letters to

Bath Twp.

And so you see

Hazel will be used to

Being busy

When she graduates from

"The Daily Grind."
GRACE LYLE

Marianna, Arkansas

Arts

Naturally

She says

"You all"

Instead of "You,"

For which

We like her

All the more;

And, while

We'll miss her

Awfully

When she leaves,

She'll probably

Come back

Now and then:

For there's a rumor

About an

Affiliation

Involving one of the

Farm Bureau's

Favorite sons.

Good-bye, Grace-

Good luck.

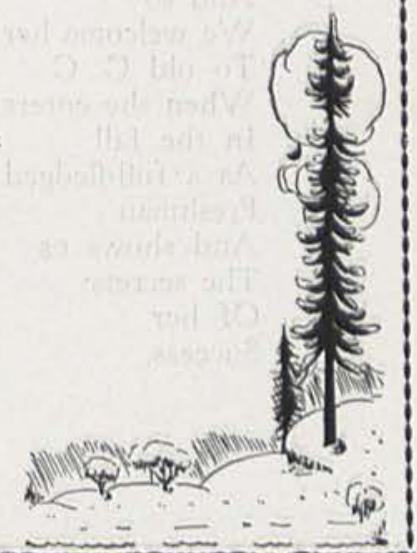

(ip) 


\section{The CEDRUS 1924}

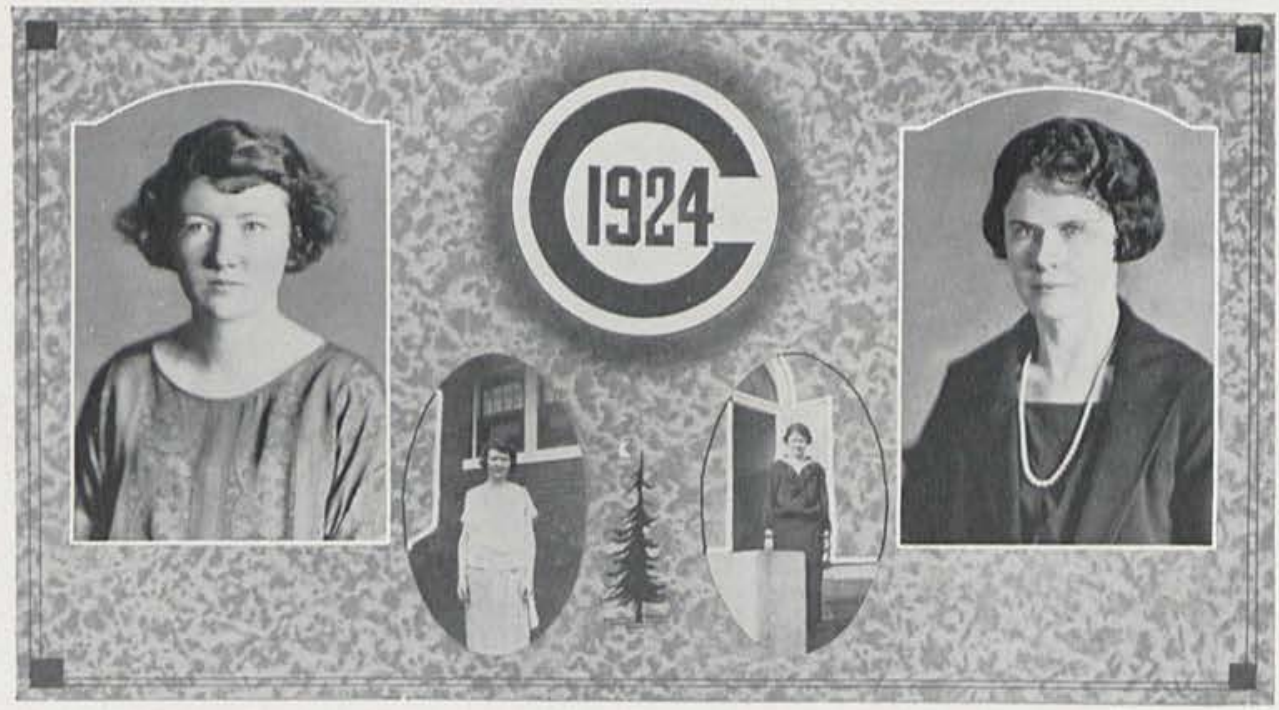

HELEN ILIFFE

Cedarville, Ohio

Diploma in Music

Being a Senior

In High School

And College

At the same time

Is a remarkable undertaking.

But prodigies are common

These days,

As Helen has proved

To our entire

Satisfaction,

By her

Beautiful playing

On the prano.

And so

We welcome her

To old C. C.

- When she enters

In the fall

As a full-fledged

Freshman

And shows us

The secrets

Of her

Success.

s

-

\section{LOIS ELDER}

A.B. Earlham 1923

Education, Cedarville

There's a Quaker

Down in

Quakertown.

But she came

Up to Cedarville

To School

After

Graduating

From Earlham

In time to see

Them beat us

In football.

But she has proved loyal;

And has shown her

Ability

By teaching us to say,

"Yes, we have no bananas,"

In Spanish,

And in driving

Down to all the

Games

To cheer

For

Us.

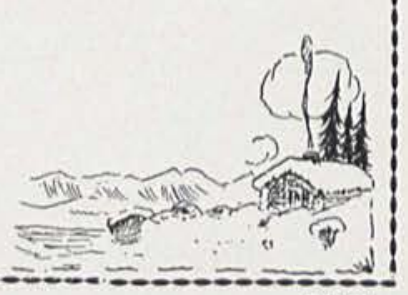




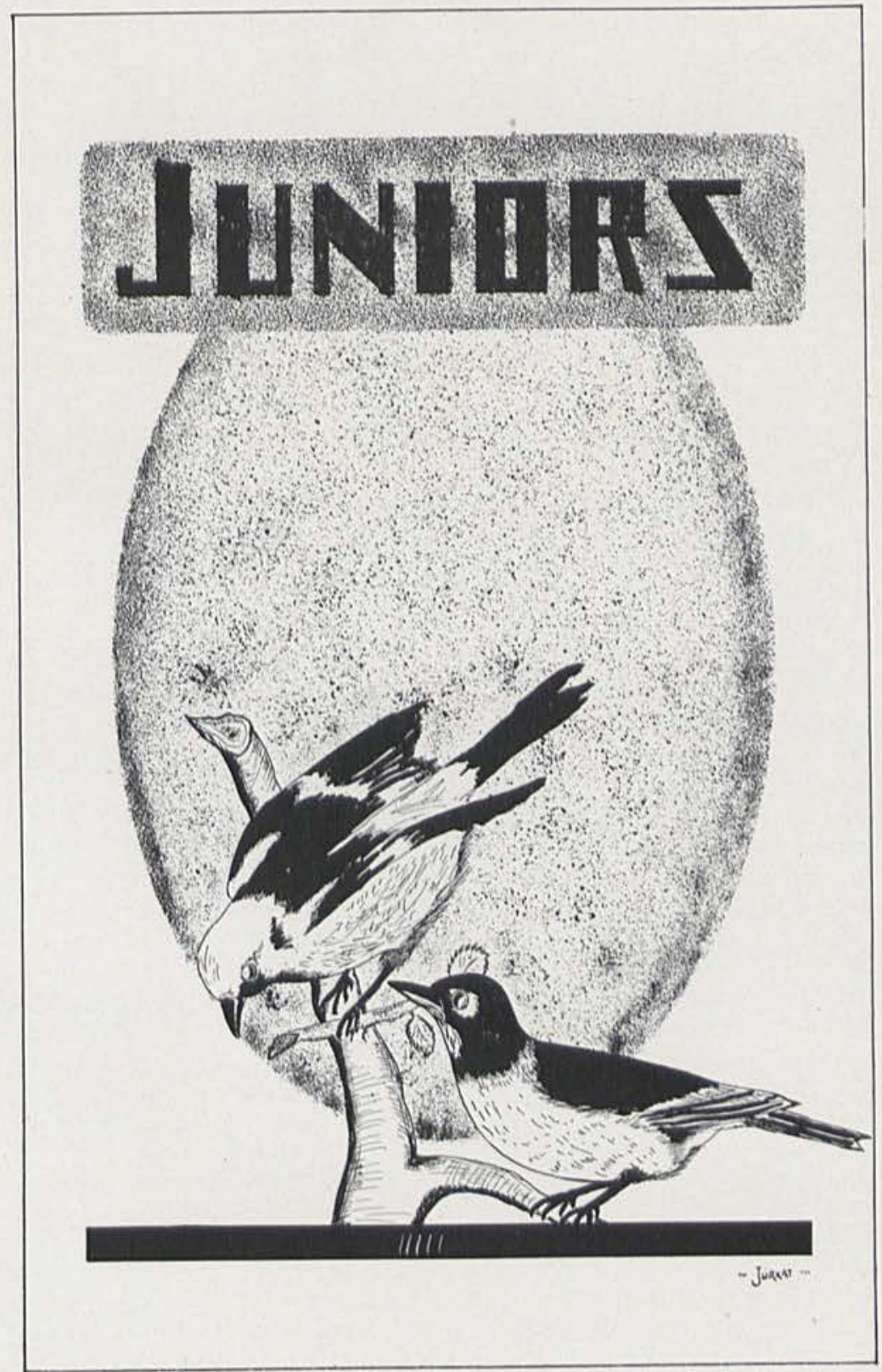


The CEDRUS 1924

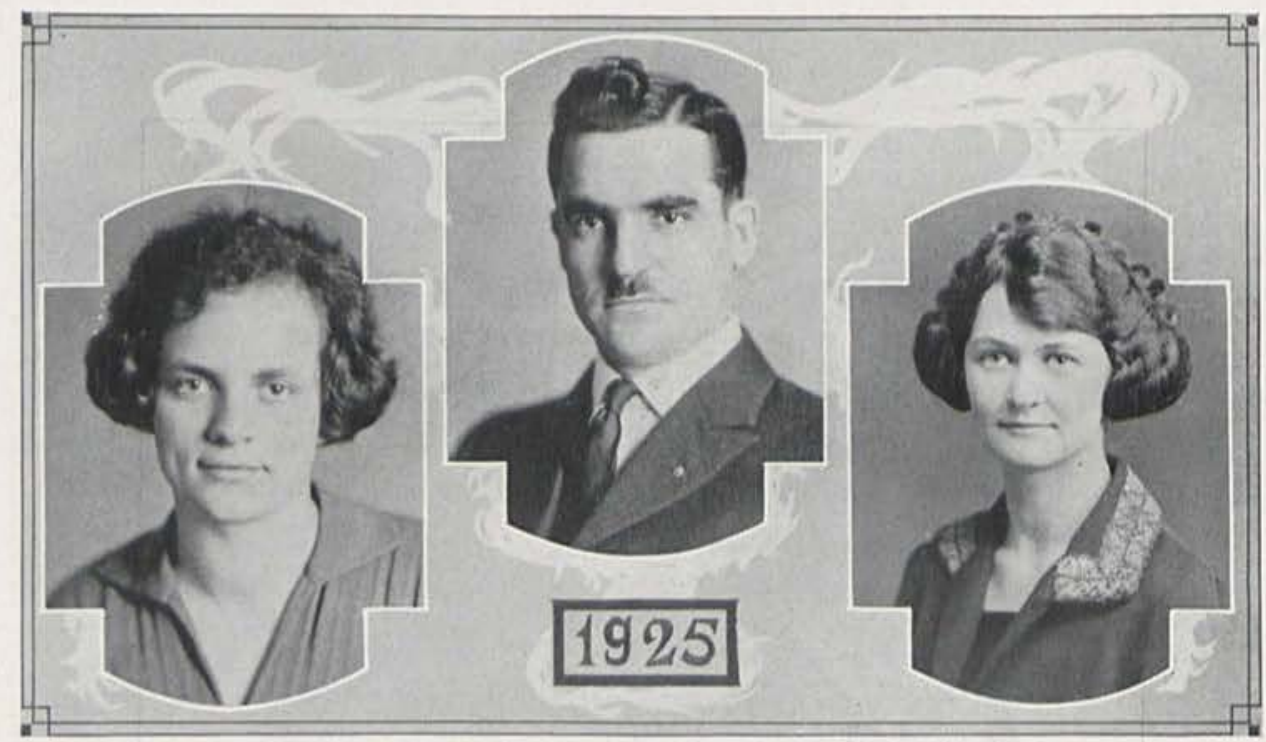

Secretary Pauline Collins

Treasurer La Clede Markle

Ruth McPherson President La Clede Markle

\section{Junior Class History}

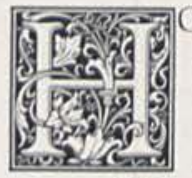

OW WELL DO WE RECALL our first morning in chapel! It was not so very long ago for we are only Juniors now. Truly, that was our first taste of college life and most assuredly we were favorably impress. ed. As Freshmen we took on new courage and began to realize our responsibilities.

Of course our Freshman life was not all work and no play; for we did have an occasional "feed." At least once we felt so sorry for the upper classmen we almost fed them, but our men had been so well trained in football that they were strong enough to prevent such a catastrophe. Speaking of sports, the college would go begging were it not for the captains, managers, halfbacks, quarterbacks, etc which our class so ably supplies.

As "Sophs" we were not so great in number, but we still had the "quality." We were well represented on the Cedrus Staff and in the college play. We were at the front in pestering the Seniors when they had their "feeds." We will say that they were blessed with "Angel Cooks""

Since time never ceases to fly, we suddenly found ourselves Juniors. Sad to relate, our ranks were greatly depleted by this time, for many answered the call for teachers. Never will we forget our "steak roast" at Larry's cabin, or the "chick en feed" at Lois', but these are only two of the many bright spots in our Junior life.

Naturally we hesitate to "laud our praises to the skies," but we are so proud of our Juniors that we want others to know and appreciate us. Our highest aim is to do the best we can for our college, with the hope that she will give of her best in return. 


\section{The CEDRUS 1924}

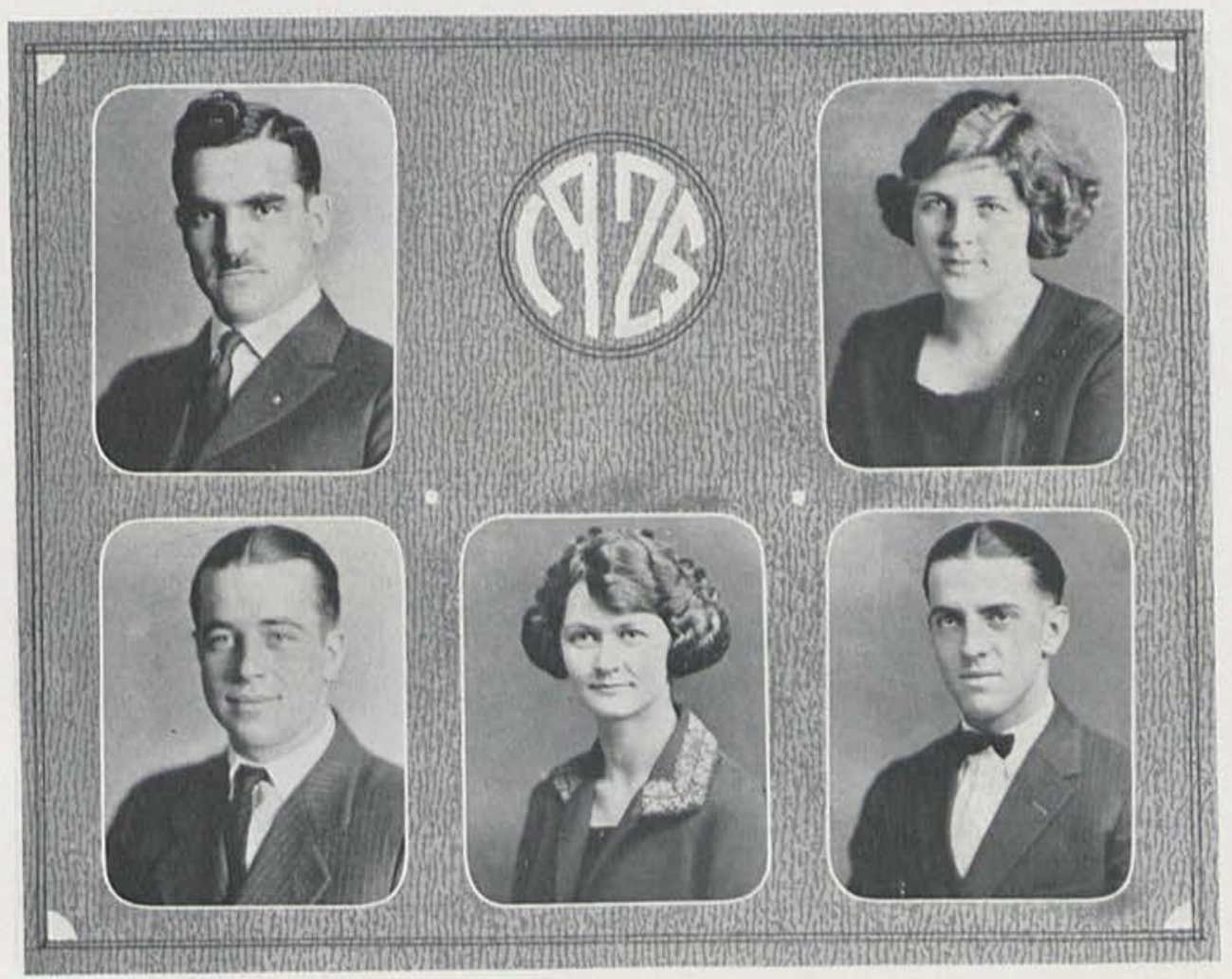

G. LA CLEDE MARKLE

Full of pep, leads in everything but his classes, a ladies man, loves to travel in the Northern part of Ohio. Clede is the life of the college.

\section{HOWARD ARTHUR}

$\therefore$ straight road and a fast machine and Handy is a happy fellow. He is also fond of the ladies.
DOROTHY OGLESBEE

One of Cedarville's most accomplished girls. Her voice is a source of delight to all who hear her. Among other things Dorothy is noted for her curly locks.

\section{WALKER TAYLOR}

Our efficient President of the Student Body, a star in all athletics. We suspicion that he has fallen in love.

\section{RUTH MCPHERSON}

One of Cedarville's most famous actresses. Her readings are always enjoyed by all. Ruth excells in entertaining a cer-

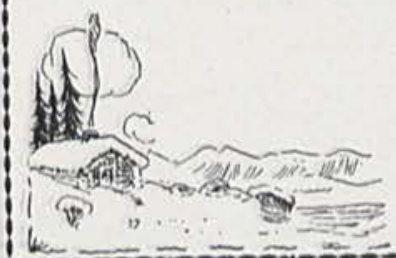
tain young man. 
The CEDRUS 1924

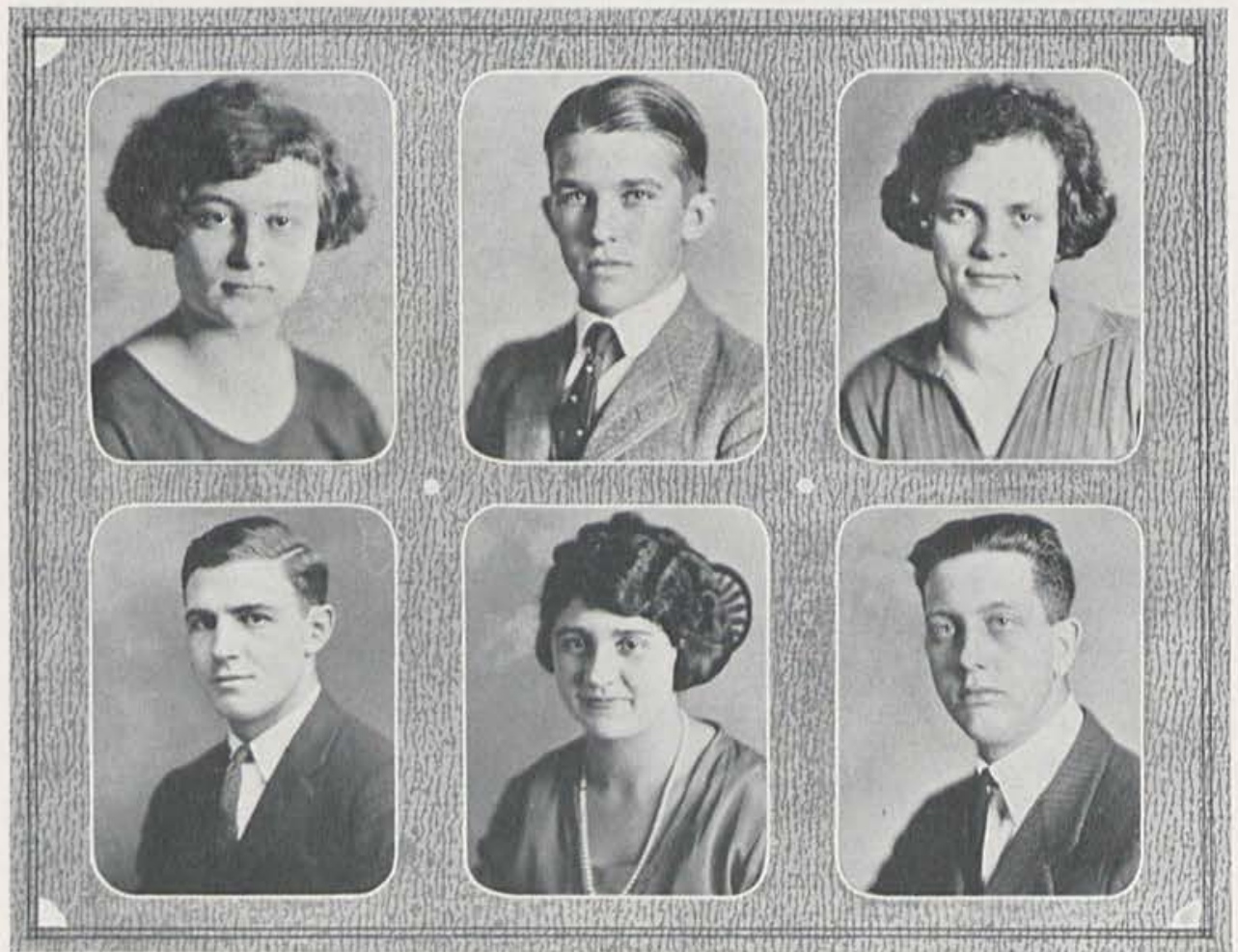

AVENELLE BRIGNER

Avenelle will be a burden to no man, she believes in making her own way, however she isn't trying to discourage any of the men. She has made a very successful teacher.
PAULINE COLLINS

A country lassie, always prominent in student activities. She is resourceful and depends on no man to crank her Ford.

\section{JOHN DAVIS}

John is little but mighty, a basket ball star who can slip under the best of them. $\mathrm{He}$ is not able to find any College girl but look out for the High School.

\section{LA WRENCE CURRIE}

Our football star, very good looking, thus a heart smasher. His heart is in a town on the shore of Lake Erie.
WILLIAM ANDERSON

Bill is from Penn. He loves to go to shows and never misses a movie, He is a step-father to fifty children every day.

\section{LOIS CUMMINGS}

When given her choice Lois will always take a "walk." One of the most beau-

tiful girls in College and a friend of everyone.
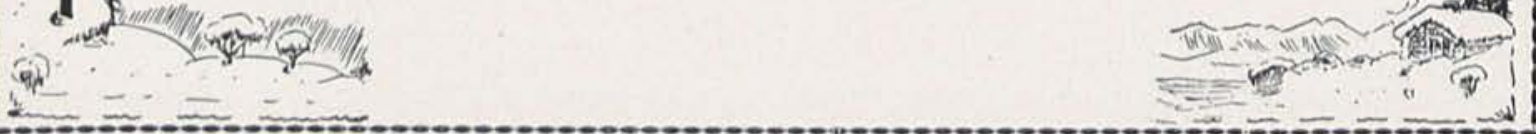

Thirty-four 


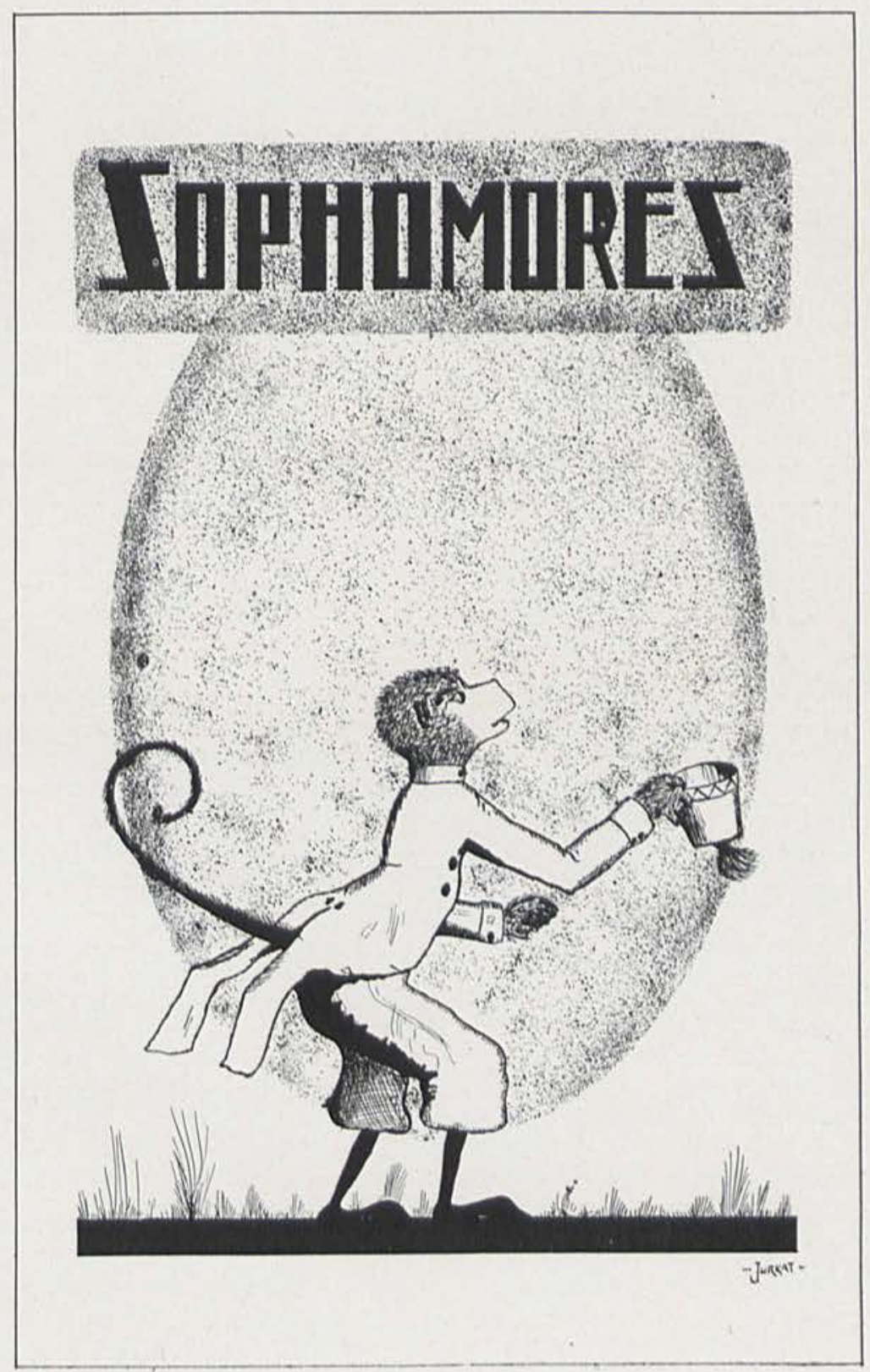




\section{The CEDRUS 1924}

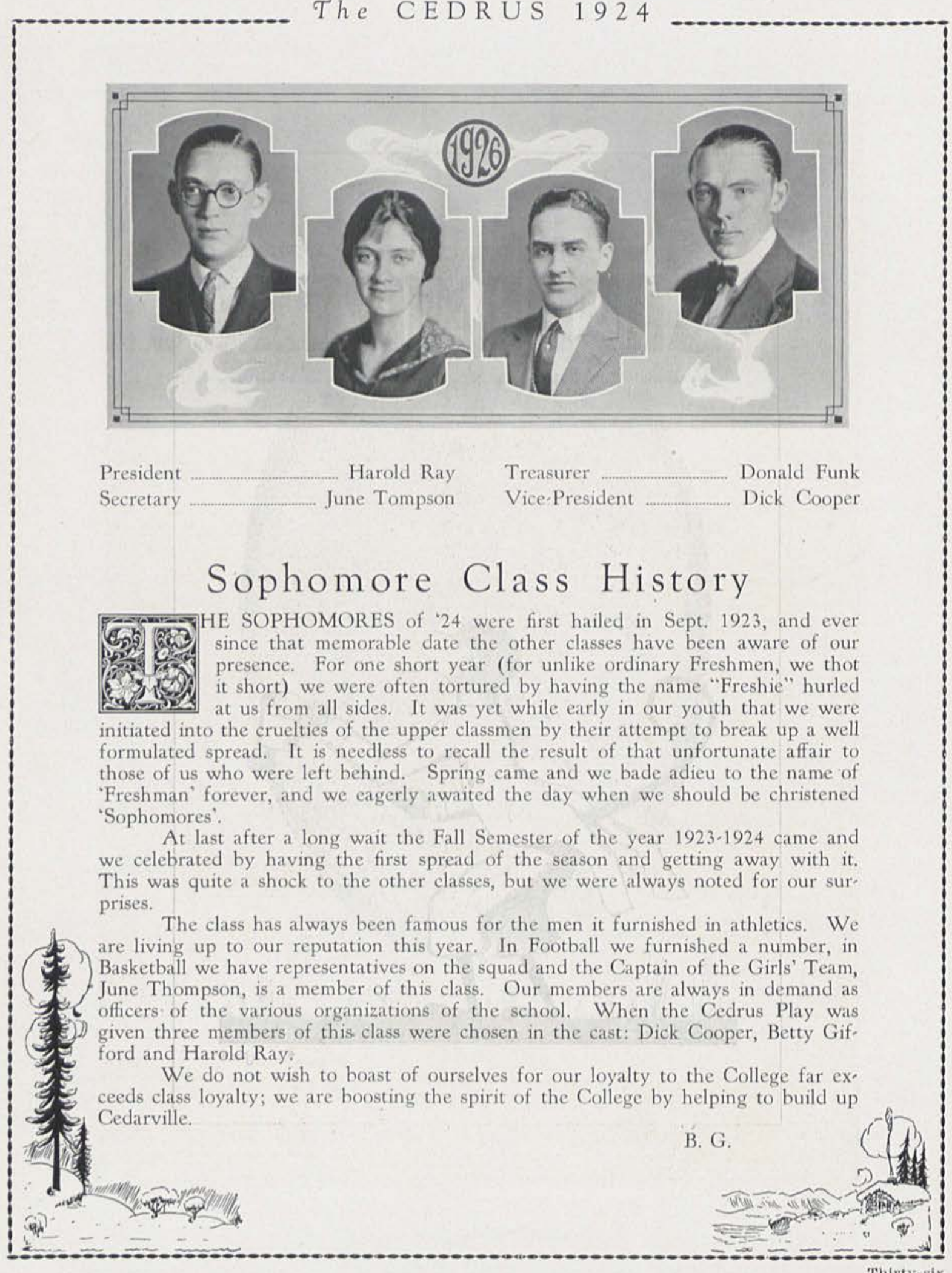


The CEDRUS 1924

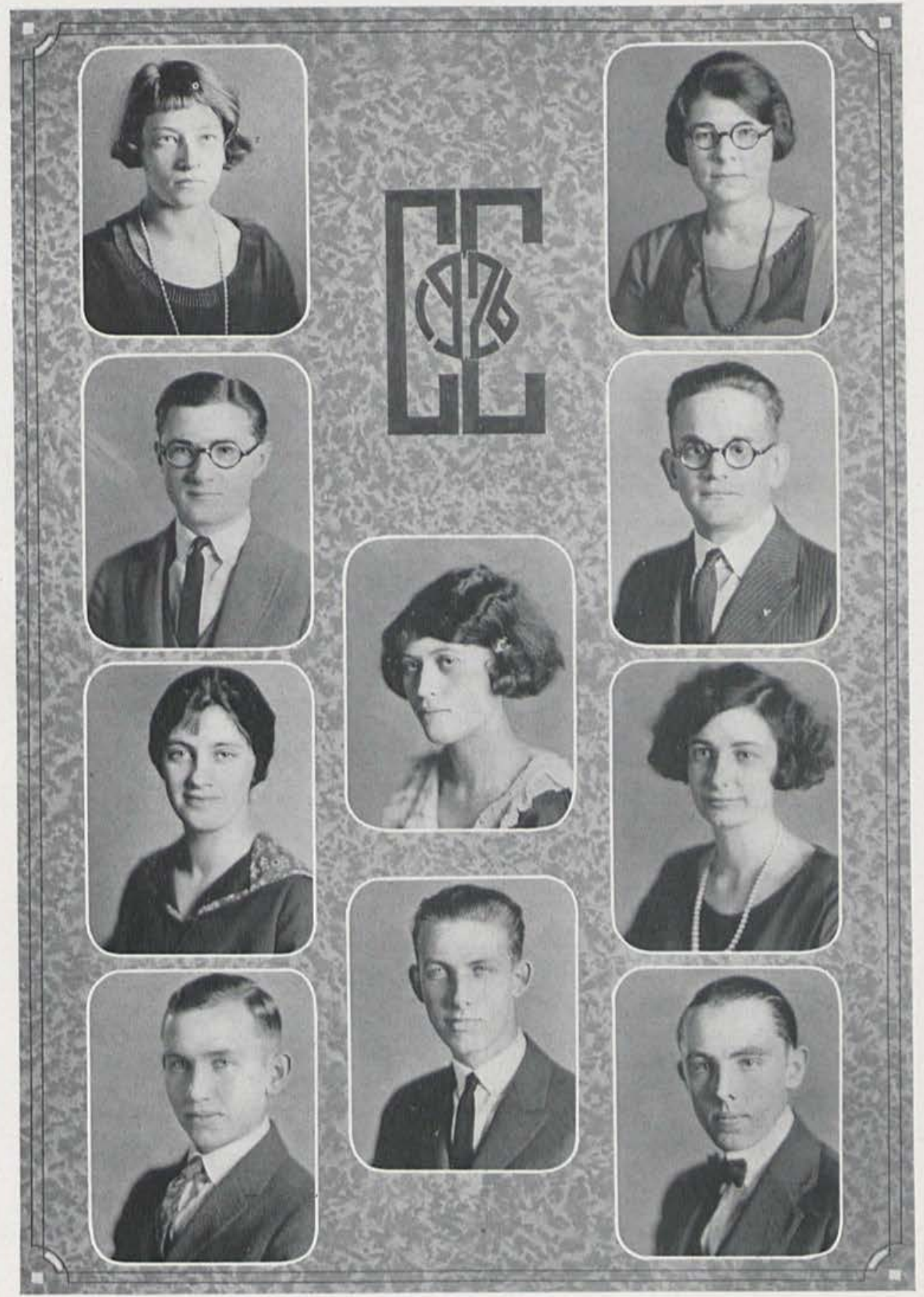


The CEDRUS 1924

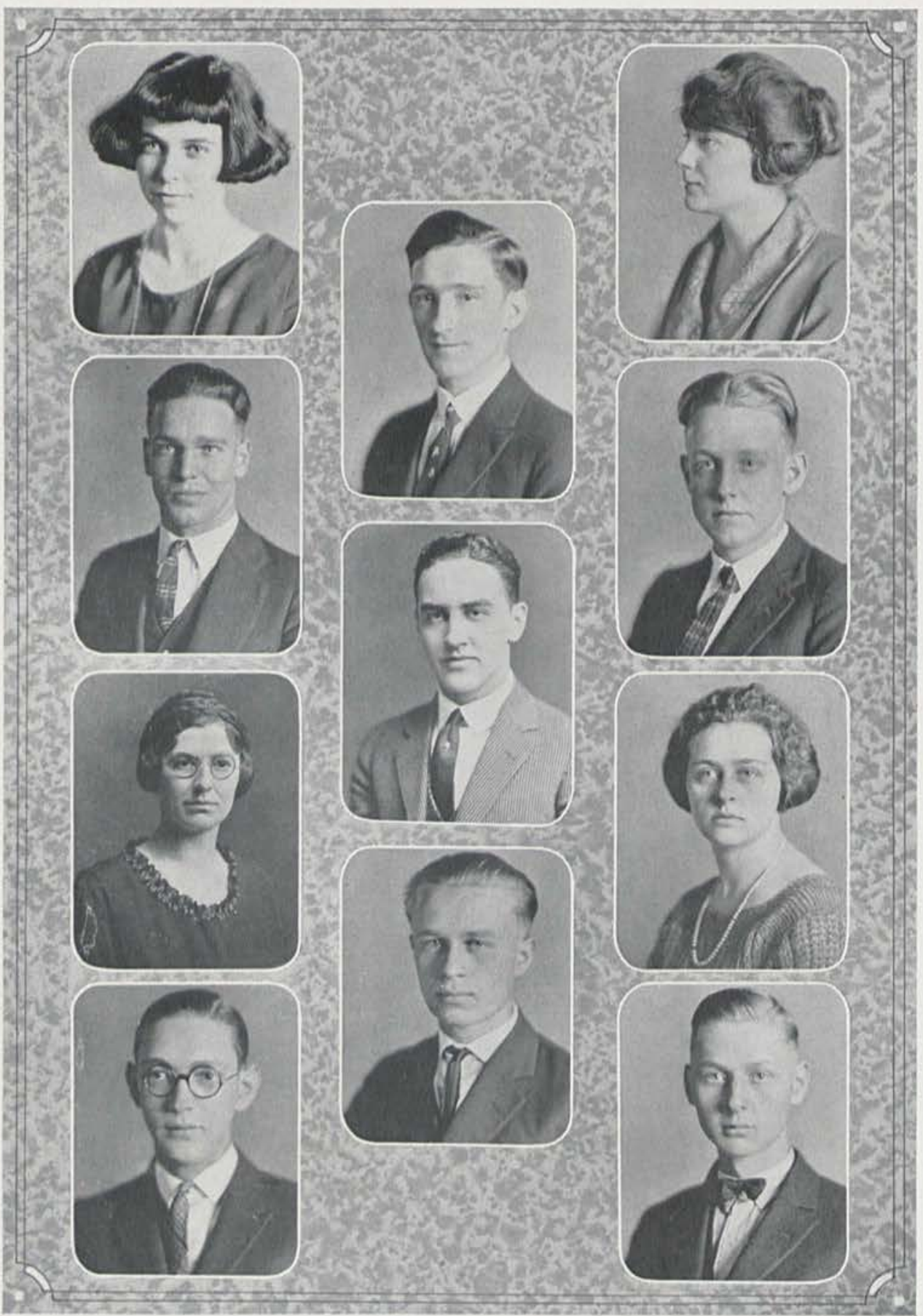




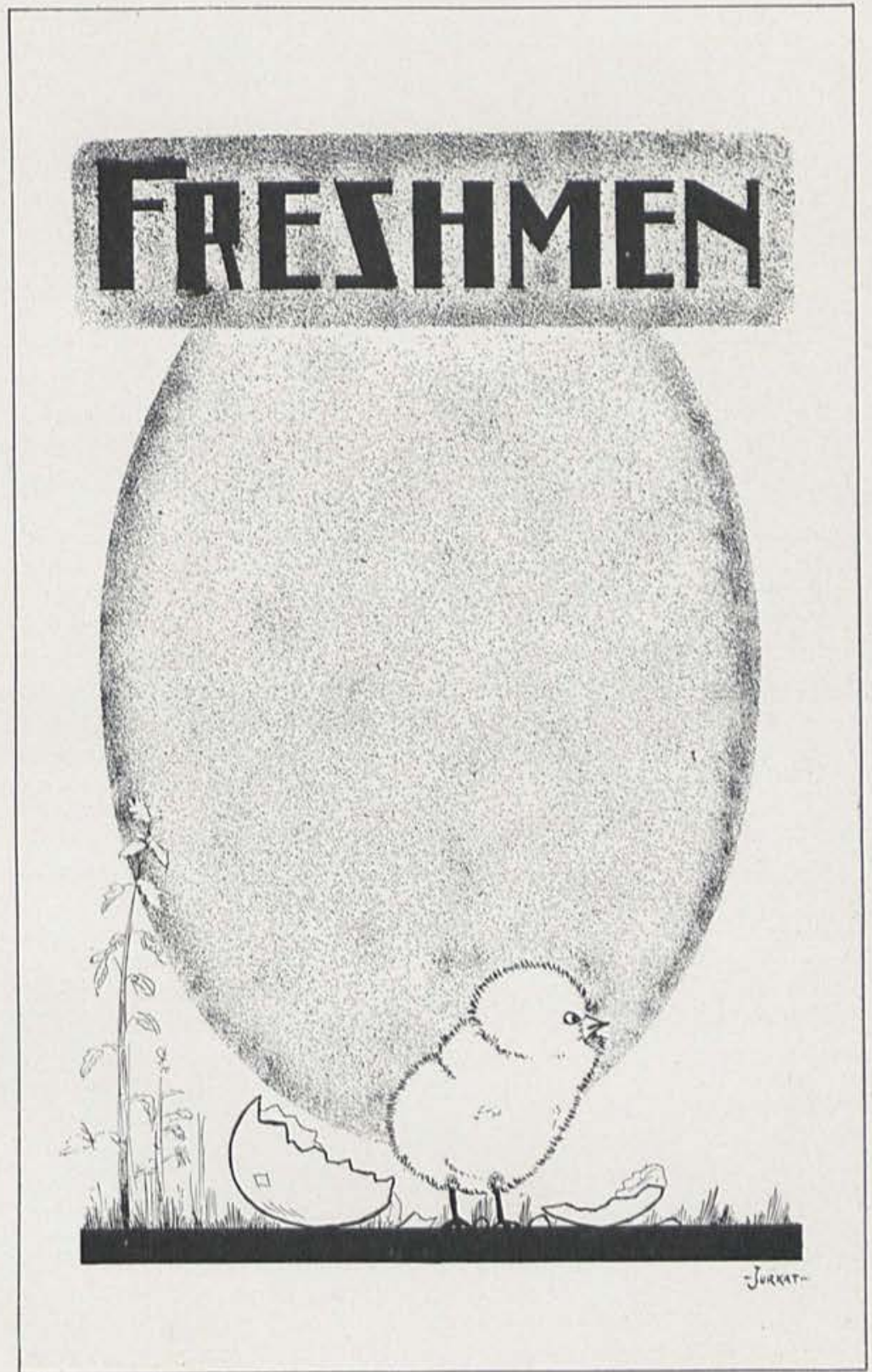




\section{The CEDRUS 1924}

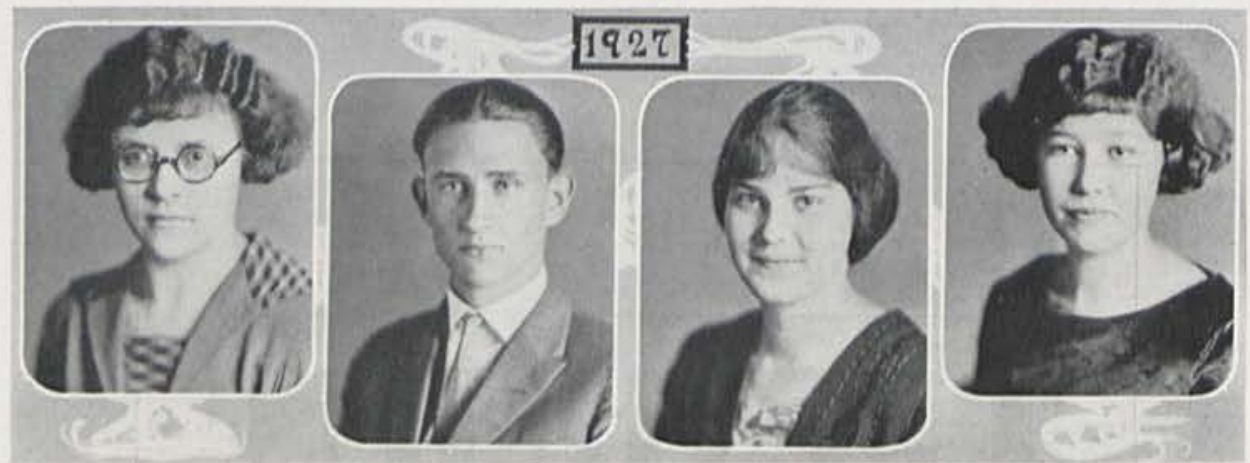

Treasurer

Mary Townsley

Vice-President

Elsie Long

President Carson Webster

Secretary

Harriet Shields

\section{Freshmen Class History}

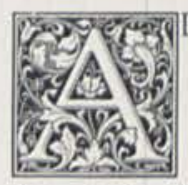

LOW ME TO INTRODUCE to you the Freshman Class of Cedarville College. Oh, pardon me! Of course it needs no introduction! By its deeds it has already made itself so prominent that no one but an ignoramus would venture to introduce it. Altho only Freshies, the members of this class have distinguished themselves (if Freshies can do such a thing) in all activities of the College.

But to begin at the beginning. We entered College in September imbued (as Freshies usually are) with the firm determination to study, and at the same time to have our names carved high on the honor roll of Cedarville College fame. It was a dark and gloomy day when we first saw the famous halls of the College. When we arrived that morning we did not know where to go and after chasing around the building we were finally herded into the chapel like a bunch of sheep. There we had our first glimpse of our professors and were given some idea of the lessons which we would have the rest of the year.

When there is time to spare from our studies we enter enthusiastically into every phase of college life. In the athletic line this class has done much considering its age; it has contributed not only quantity but quality. We refer you to the pictures of the teams in this volume of the Cedrus. This class supplied many of the cast for the college play, "The Importance of Being Earnest," and also for the Ced. rus play, "The Wrong Mr. Wright."

The class had its first social stunt by taking a ride on a truck. Most of the upper classmen followed us and seemed to have a very good time, lacking only one thing-refreshments. Chagrined by this, they brought back to town several samples of Freshmen hair to adorn Doc's window.

Just when we thought that we were getting along wonderfully and that every one had forgotten that we were Freshmen, the upper classmen kindly informed us that the boys were to wear caps of college colors with a green button on them, and the girls were to wear the college ribbons. In no better way could the college colors have been honored than by permitting us to wear them.

There you have the story of the class of ' 27 . If you are willing to concede that we are "some" class - all right; if you are just a bit skeptical-just watch us and we will show you that we are a class of which Cedarville College may well be proud.

D. W.

aip... 
The CEDRUS 1924

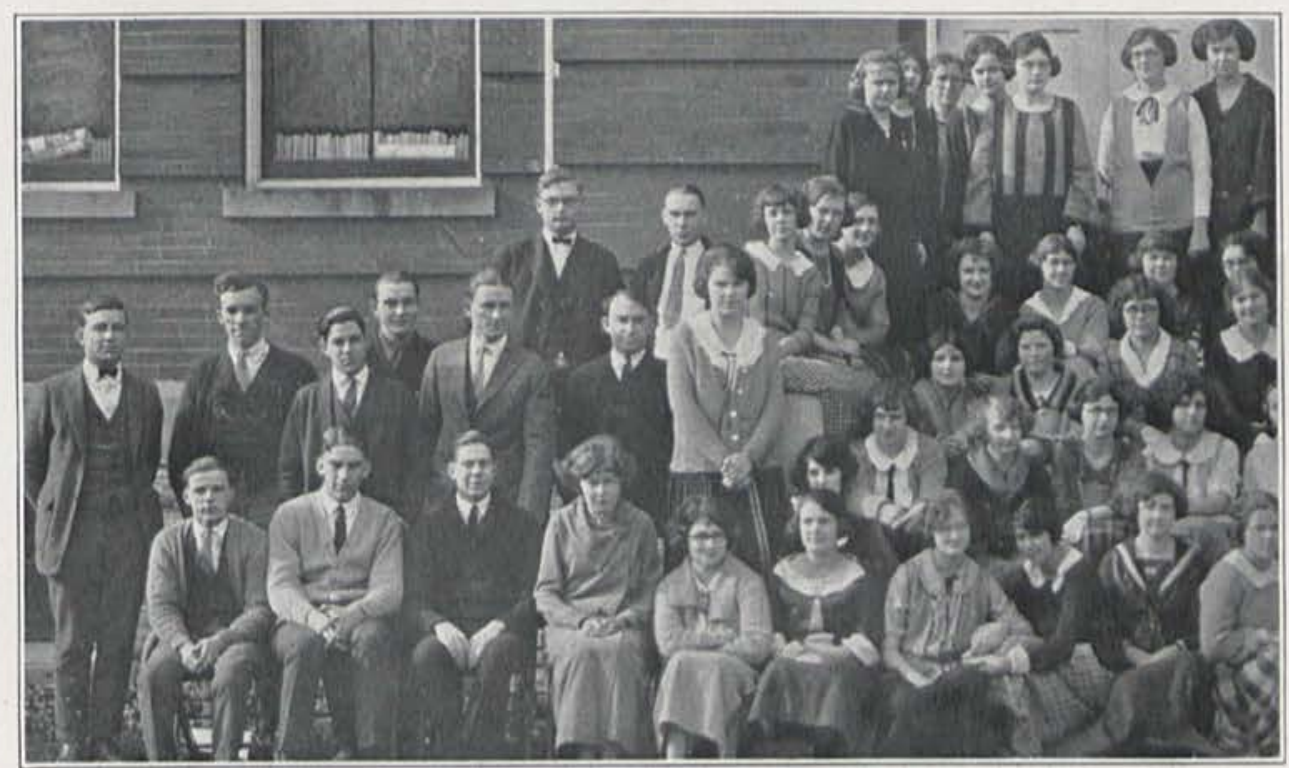

Freshmen Class Cedarville College 1923-1924

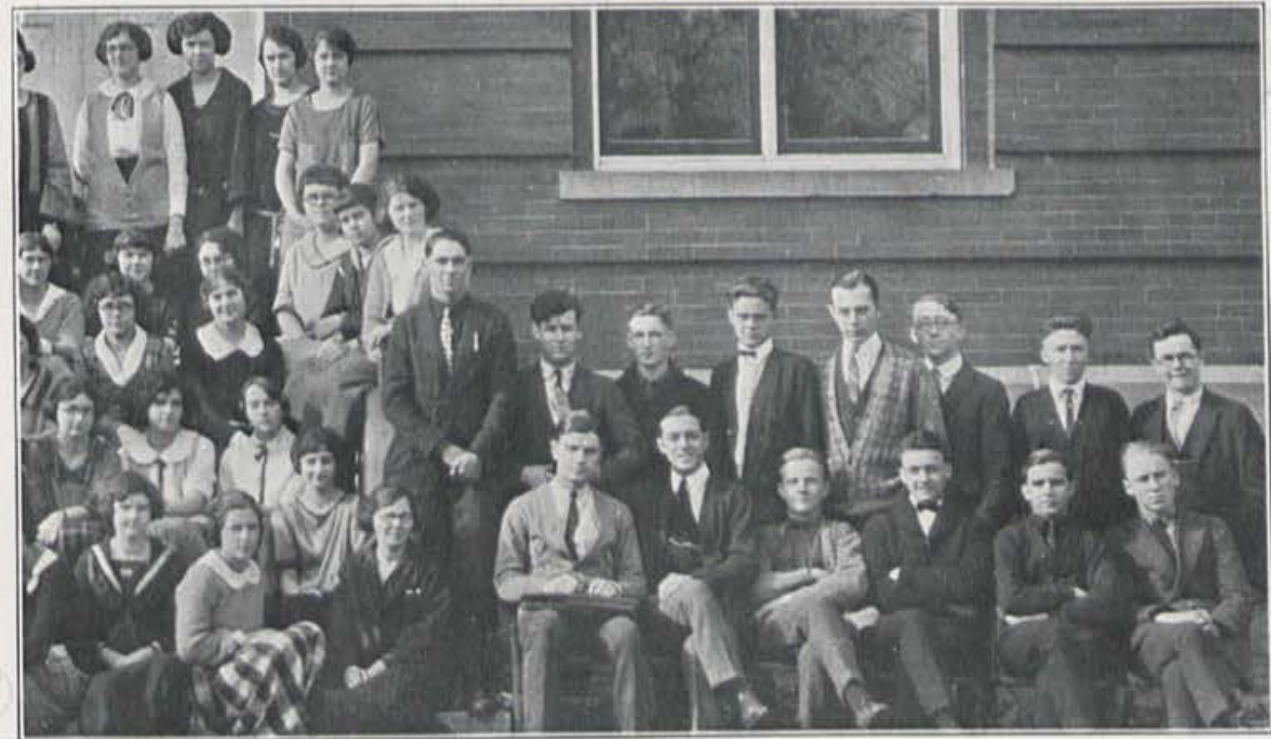


The CEDRUS 1924

\section{Green County Normal}

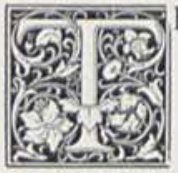

HE YEAR 1923-1924 marked the beginning of the Greene County Normal School at Cedarville. The College kindly offered the use of a room on the main floor of the Administration Building in which to conduct it. This was accepted as a suitable place. This has proven a great ad. vantage to the Normal School because it enables the students to come in close contact with the college life, and associate with the college students. This is something that one does not find in many Normal Schools. Here the Normal students are considered and treated the same as Freshmen of the College. It also gives them the opportunity to attend chapel services.

The Cedarville School is situated across the street from the campus. This also serves as an advantage to the students. It enables them to do their practice teaching and observation close to their boarding places. In this way they are not to any extra expense.

The establishers of this Normal School have been governed in their choice of material and methods of treatment by the needs of the rural teacher of today. The purpose of this Normal is to prepare teachers who will turn the drudgery of the rural school life into pleasant and interesting work.

Everything that is essential for the preparation of a rural elementary teacher is given. Not only the methods of teaching are taught, but also a course in every elementary subject, including music and industrial art. This enables the student to have a good control of the subject matter before he begins his profession of teaching. Thirty-six hours of observation are required. At the end of the course the student is given a one year teacher's certificate.

At the beginning of the first year nineteen students enrolled, eighteen girls and one boy. The class had the misfortune of losing two members, but those re. maining worked diligently through the course.

This school was very fortunate in securing a most efficient teacher, Miss Susanne M. Koehler, of Columbus, Ohio.

In the month of December Mr. Eswine from Columbus gave this class a very interesting course in Nature Study and Agriculture. In March the class was fortunate in observing Miss Morrow's and Miss Elliott's reading in the primary grades.

Although the Greene County Normal is rather unfortunate in having a green name, it is very evident that this does not seriously handicap it in any way.
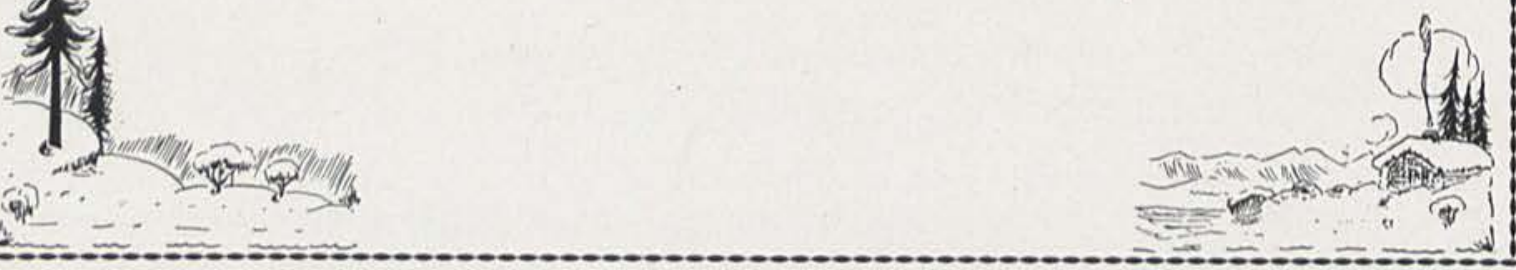

Forty-two 
The CEDRUS 1924

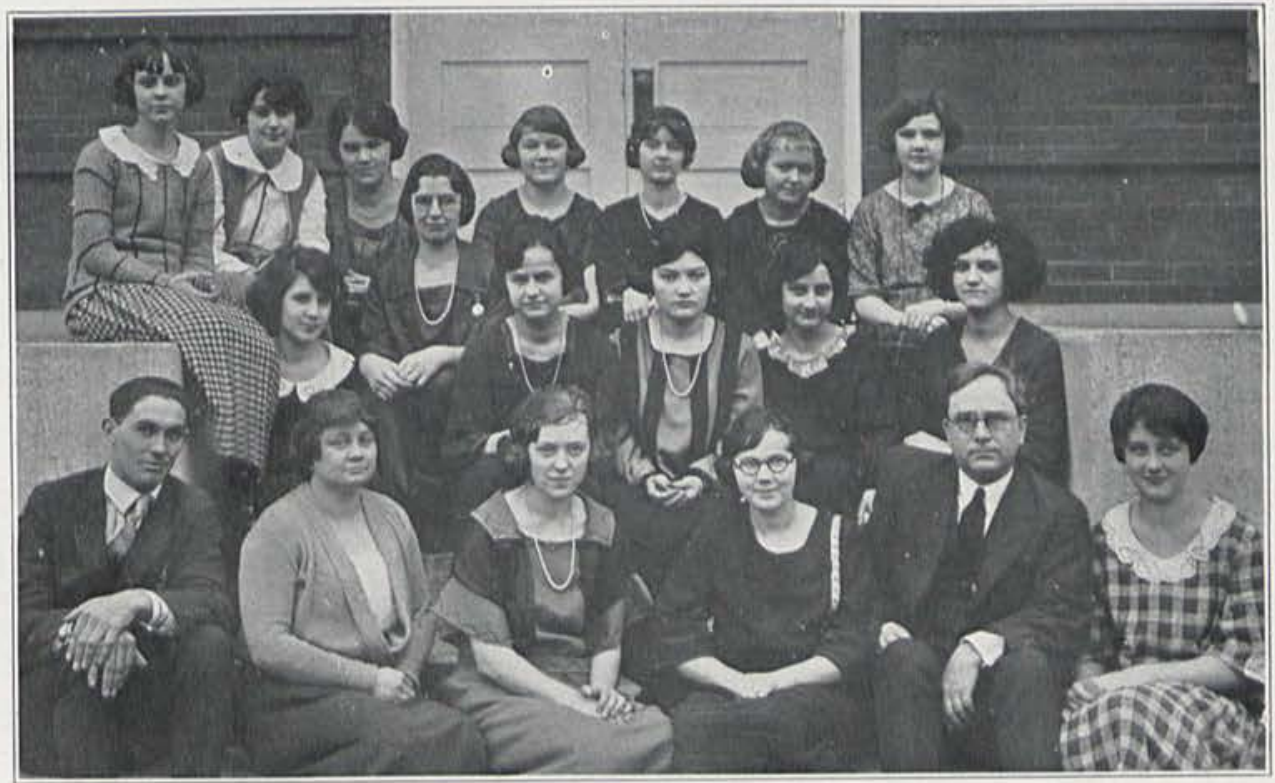

\section{Normal Students and Professors}

Frances Ginn the lead does take,

A star teacher she is sure to make.

Wanda Hartsock we all love to hear,

As she sings with her voice so sweet and clear.

Next comes Esther who would argue all day.

If a question she could win her way.

Edith Brown the Arithmetic star,

For higher success she'll not have to climb far.

Lenore Lewis so sweet and true, of her kind, there are but few.

Next comes Lois who some day will be, The greatest artist you ever did see.

Emma Hazard whom English does take, But is determined a good teacher to make.

Ethel Beals the story can tell,
So that children understand it so well.
For piano players we must confess Dot Queary is the best.

Next on the list comes Grace Baughn The girl of whom we are all very fond.

Eva Willet we all must say

Controls her pupils in the very best way.

The girl who is quiet in her way

Is none other than Miss Ruth Gray.

A kindergarten teacher we have in our midst.

Flo Hughes, few like her exist.

Two girls who to their class are true Mary and Ruth the sisters Two.

Verna Boase another teacher to be, And a good one you will see,

Last on the list comes Lew McCoy, In our class the only boy.

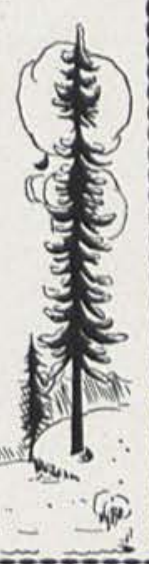

Forty-three 
The CEDRUS 1924

\section{Department of Music}

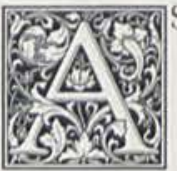

YOU APPROACH the College Library, and raise your eyes to the window at the right of the entrance, you will see the sign DEPART. MENT OF MUSIC; then when you are ransacking the shelves for a book to read, perhaps you will hear the melodious strains of a Bach Invention or Beethoven Sonata coming from the studio in the rear; and you will realize that Cedarville College does have a Department of Music. This Department was established several years ago; and since that time it has been slow. ly, but constantly, growing. Already plans are being made for improvements to be instituted next year.

The Department of Music is conducted under the very efficient instruction of Professor J. A. Talcott, M. A. Professor Talcott is a graduate of the Cleveland Piano School, the Georgia School of Technology, and the Royal College of Organists at London. He has also studied voice under Charles S. Burnham, and choir direction under J. Powell Jones of Wales. During the past year Prof. Talcott has offered courses in piano, organ, voice, and harmony. A course in violin will be add. ed whenever the demand for it is sufficient to secure the services of a teacher from Springfield. In the past the instruction has all been given individually in half-hour lessons; but in the future the work in harmony will be class work taught by the lecture method. The work for each course is mapped out, and when the course is completed a diploma of graduation is given. A public recital is held every June to demonstrate the work of the Department and to give the pupils training in public appearance. The College encourages work in music by allowing a total of eight credits in music to count towards the electives in the Art Curriculum .

This year thirty-six pupils have enjoyed the instruction in the various courses, The students come from the public schools, high school, college and community. More pupils are expected next year and arrangements are being made to accomodate them. In addition to the regular work, the Department has given a course in Pub. lic School Music to the students of the Greene County Normal.

A new feature for the coming year is to be the advanced department. The work in the past has been mainly primary and intermediate. Now pupils of ability will be encouraged to continue their work in the new department. Professor Tal. cott will devote more of his time to advanced work, and will be assisted in the primary teaching by some of the older music students.

A great improvement was made this year when the studio was moved from the Administration Building to the Library. The present studio is larger and much more convenient and attractive. However, we are all looking forward to the day when the Music Department will have more students and instructors, several studios, and practice rooms for the out-of-town students; and when Music will be a benefit recognized by more students.
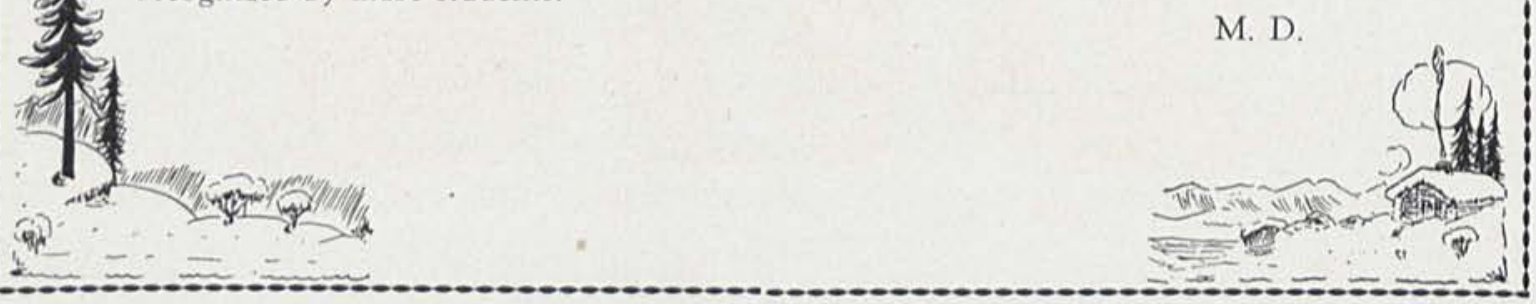

Forty-four 
The CEDRUS 1924

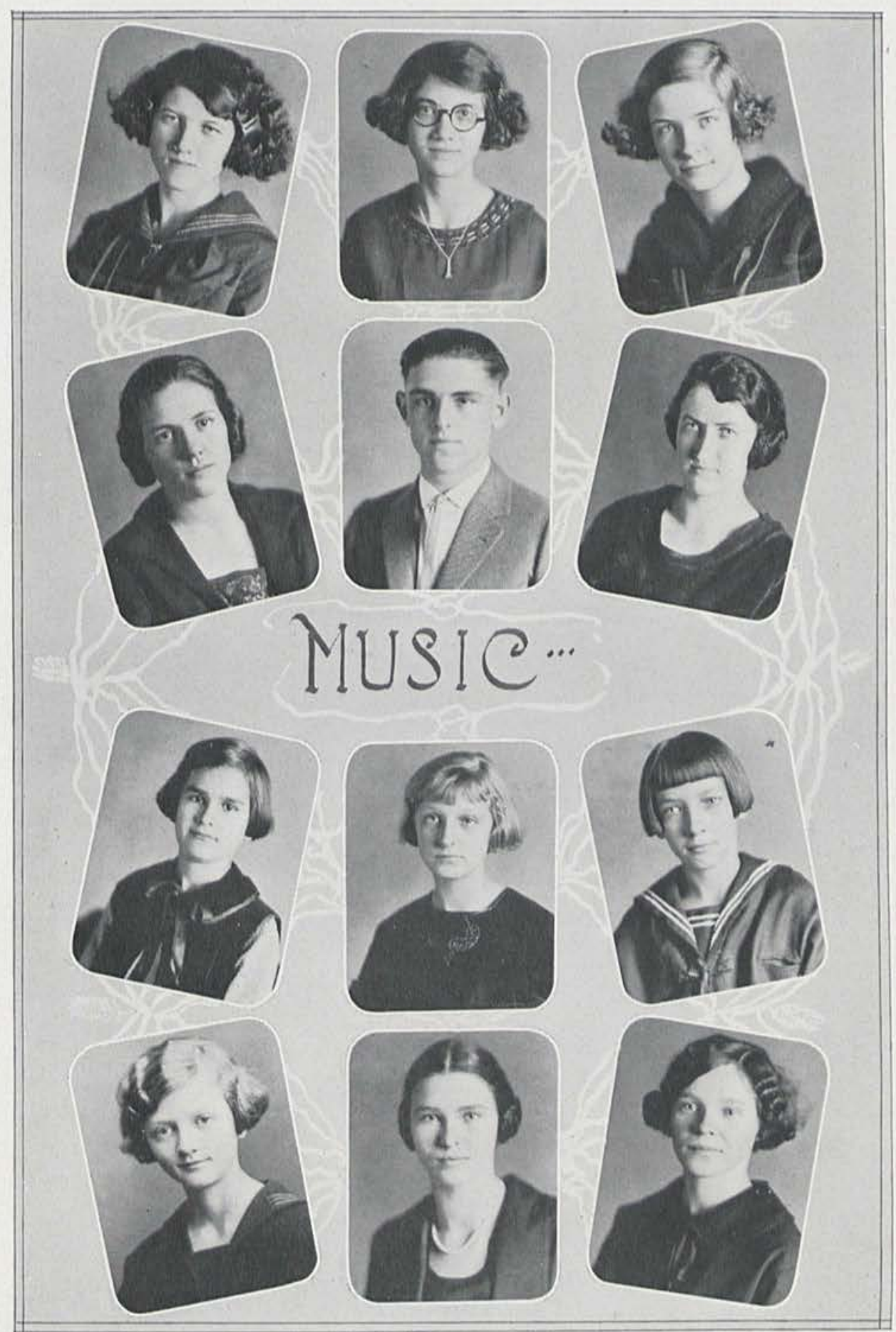




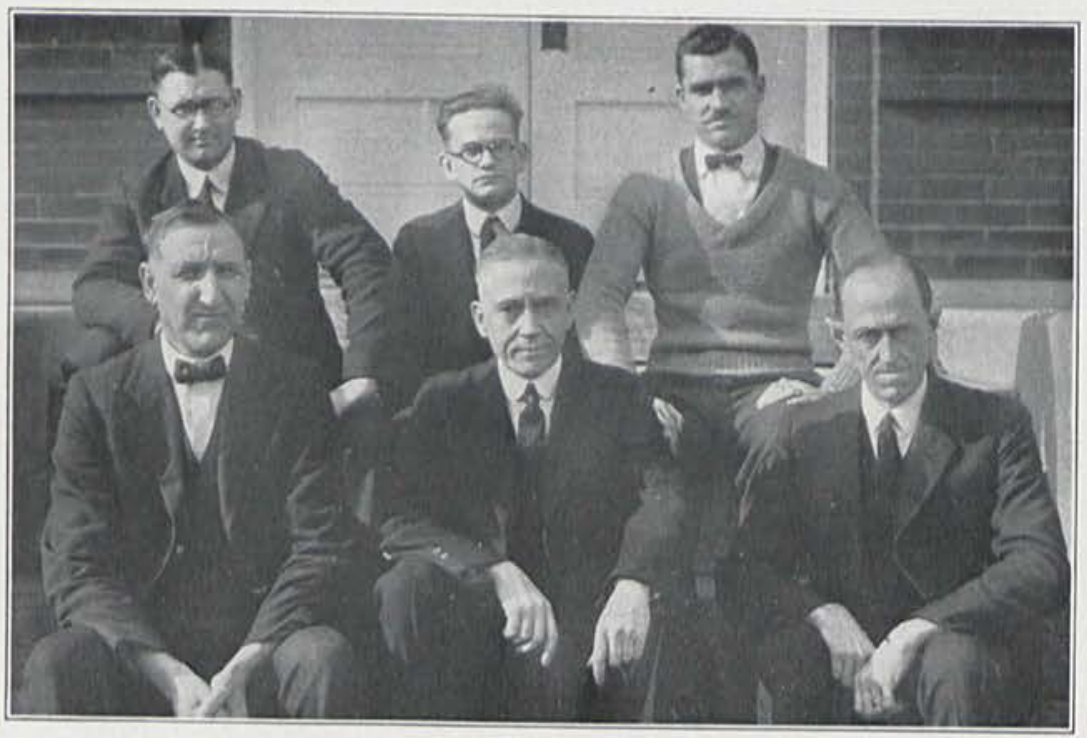

\section{Cedarville Theological Seminary}

Cedarville Seminary is a term revered by all who know its true worth. It would be futile to attempt in this limited space a systematic analysis of its comprehensive work. We all seem to have the tendency at times of desiring deeper spiritual insight into the things of spiritual discernment, but we do not always know the preferable trend of investigation to secure this desired information. This our Seminary strives to supply.

Cedarville Theological Seminary has chosen a distinctive channel of activity, and in abbreviating that plan we would sum up the kernel into one comprehensive whole: we believe there is a possibility of the loving and true God as revealed in Jesus Christ. To provide the means of laying hold of this possibility is the function of our Seminary. Sometimes under its tutelage we are led into the field of profound scientific investigation; sometimes into the realm of reconstructing the thought of former divines; again into the mental struggle of translating from the original the thoughts of the Patriarchs, or Apostles of Jesus. All this we count joy, to be able to say: we know not all, but a little more and with it to realize that to know more is to love more.

We have a staff of professors of which we are justly proud; Dr. W. R. Mce Chesney, Dean, associated with him, Dr. F. A. Jurkat, Rev. B. E. Robison, Rev. W. P. Harriman. These men are all of high character and intellect.

To any who may read and be considering the course we take special delight, after five years personal experience, in recommending Cedarville Theological Seminary as sound, scholarly, spiritual, and profoundly interested in the work of the Kingdom.

\section{G. S. R.}




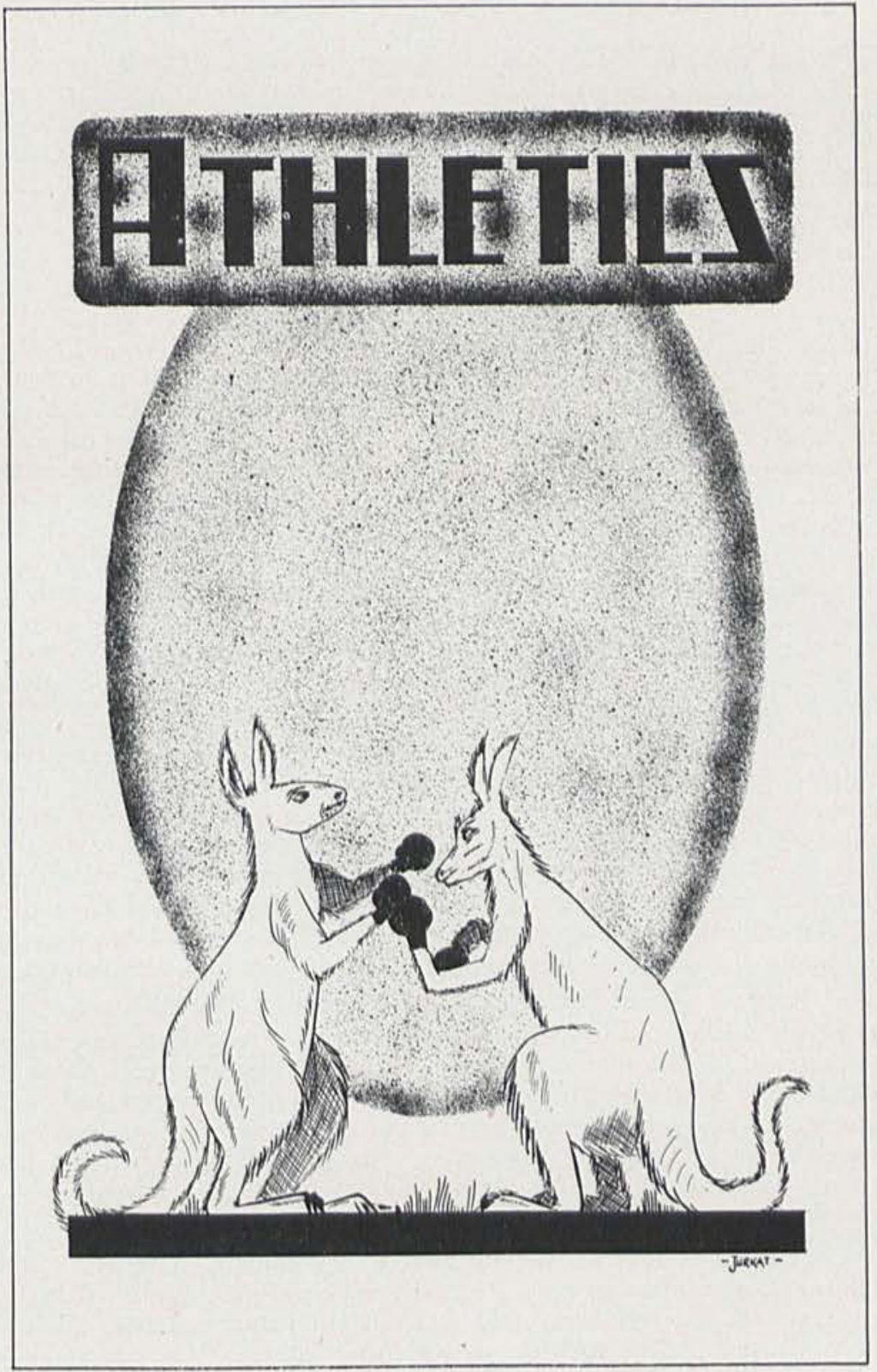


The CEDRUS 1924

\section{Athletic Review}

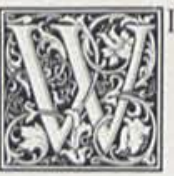

ITH THE FOOT-BALL and basket-ball seasons at Cedarville over and prospects of a good base-ball season in sight, we can safely make the statement that the athletic seasons of 1923-1924 at Cedarville have been the most successful, financially, in the history of the College. Although there may be a small deficit, it will not be as great as in former seasons.

From the standpoint of games won, the foot-ball season was an unsuccessful one indeed. One game won on the entire schedule. At the first of the season with over two teams in uniform on the gridiron things looked well for a very successful season. However, before the season was well under way the squad had dwindled until at times it was hard for the coach to get a full team for practice. Lack of observance of training rules was also in evidence, as our team on several occasions played their opponents to a stand-still the first part of the game, but were not able to stand the pace the second half. In the first game with Antioch, ten days after the opening of school, it was lack of sufficient time for conditioning and not because the boys did not try their best. They out-played Antioch in all departments of the game the first half, but were completely worn out at the close of the third quarter. In other games later on in the season the fellows showed lack of interest and fight. An "Oh, what is the use" attitude. We have men with the ability to put out a winning team. To make a winning team the men must appear daily for practice; observe training rules; have the support and proper co-operation of the Faculty and Student Body.

The same can be said of the boys basket-ball season that has been said of the foot-ball. Lack of faithful practice; lack of coroperation among players and with the coach; no observance of training rules. The final game with Antioch was one of the bright spots. In that game the boys demonstrated what they could do with coroperation among themselves and the backing of the students and commun. ity. With such playing throughout the season the scores would have been quite different. Again in the Defiance game at Dayton with the score 19 to 9 against them at the end of the first half, the boys came back with the old determination and won the game 25 to 23 . That's the kind of spirit we want at all times.

The girls' basket-ball team is a different story. From the standpoint of number of games won, in the number of girls who daily appeared for practice, and in the splendid spirit of co-operation among the girls on the squad and toward the coach, the season has certainly not been a failure, but a credit to the girls themselves as well as to the College. They won a majority of the games scheduled; taking two from Wittenberg and two from Wilmington; losing two to the Antioch girls by small scores. Hurrah for the girls!

Just one other athletic activity needs to be mentioned. The tennis club hopes to put a team on the court to contest nearby colleges. Heretofore they have had tournaments among the members, only with an elimination contest, the winner of which receives a prize. We wish the new venture success.
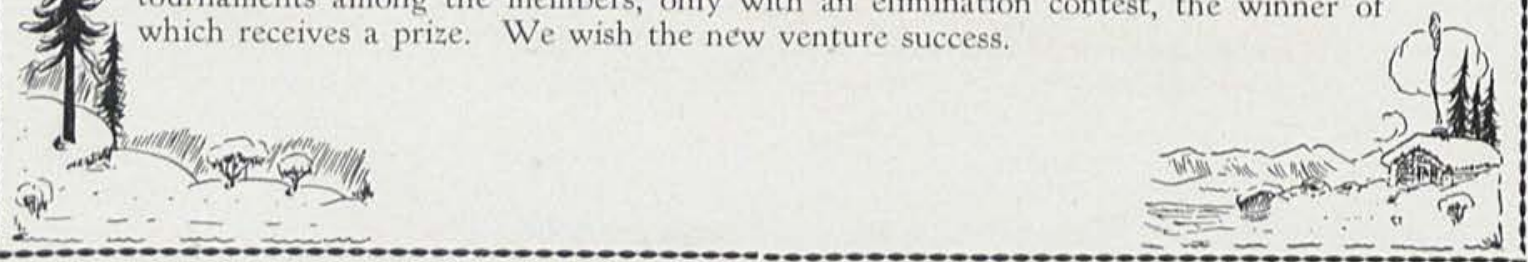

Forty-elght 


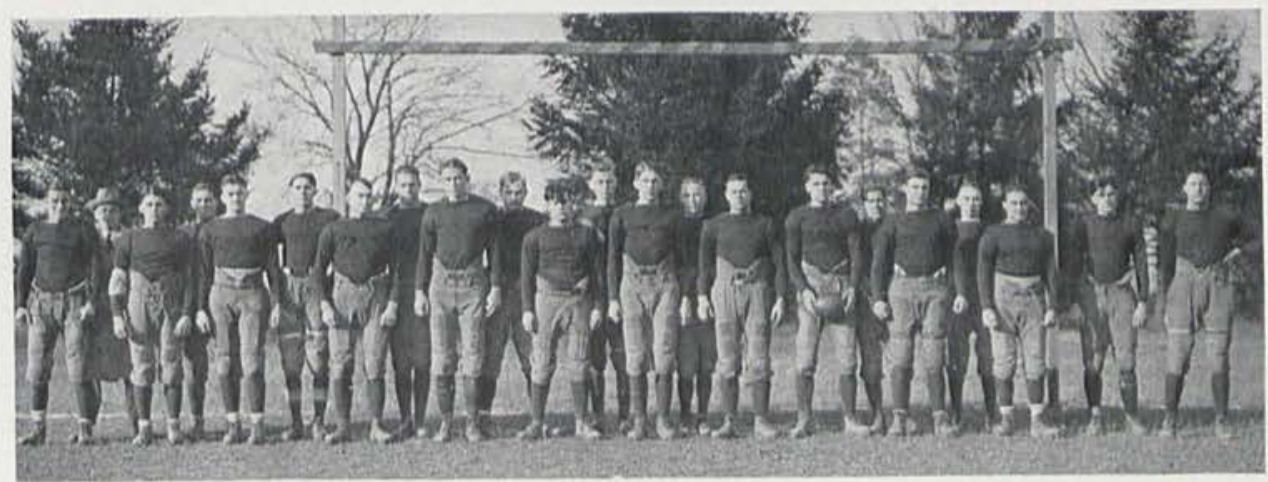

\section{Football Review}

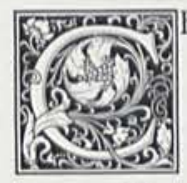

EDARVILLE COLLEGE received its first taste of football in 1921. Finding that the taste only made a desire for more we have continued every year since. The team that went on the field this year is the third team to be put on the field. Each year the main difficulty has been to get enough out to practice and it is the sincere hope that the coming team will not be handicapped by this trouble.

When Coach Talcott first called practice, on Sept. 12, about thirty men of various abilities answered, and donned thirty football suits in preparation for the initial struggle with Antioch. The team had only eight practices, and comparitively few scrimmages, before they had to journey to Antioch. The game was hard fought and early in the game Markle made a touchdown. This made us very enthusiastic and we were in great spirits. Luck was with Antioch and, due to a fumble, they scored. Antioch was completely outclassed in every respect but scoring.

The next game was with Findlay, and was played on our gridiron. The teams battled in the middle of the field, back and forth they struggled. Our team

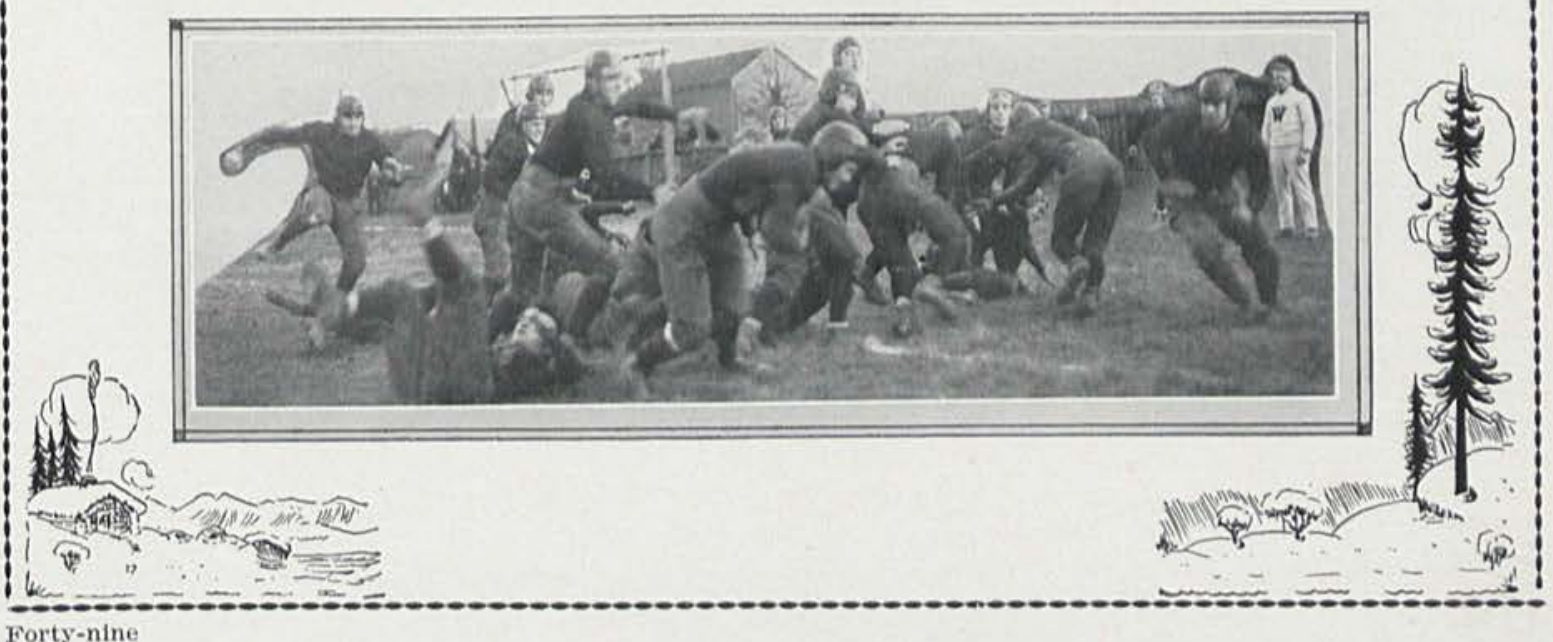


The CEDRUS 1924

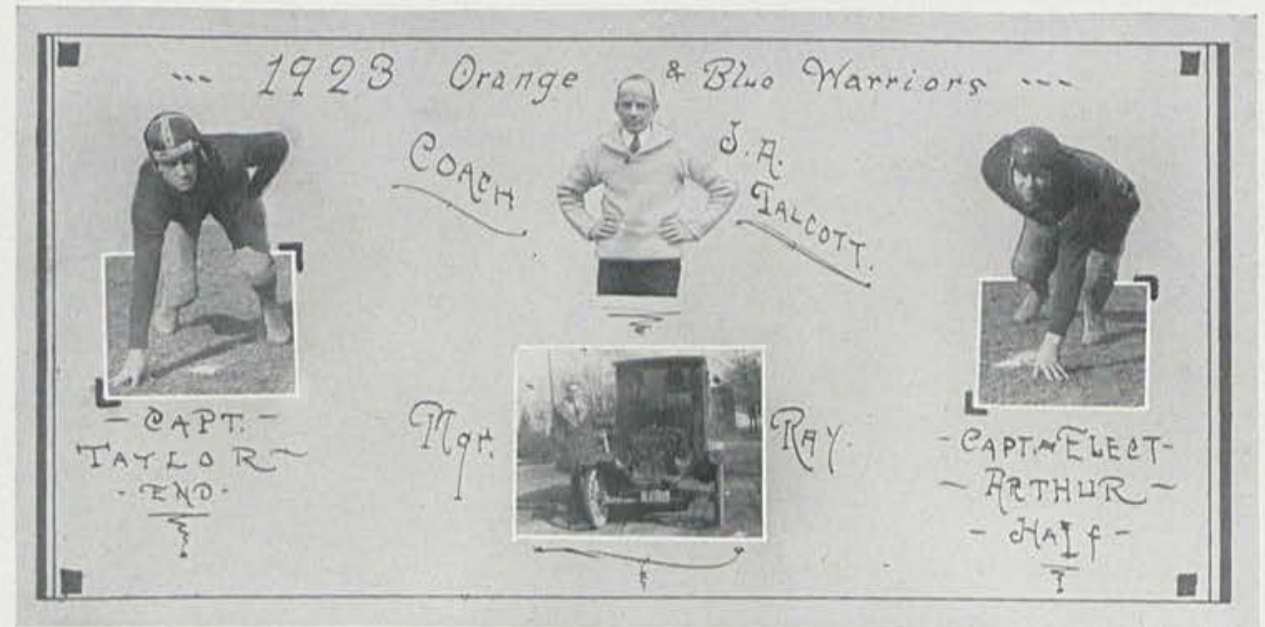

had them outplayed, however, and almost at the end of the fourth quarter we went through for a touchdown. By this time the team was in better shape and was able to put up a hard fight.

The team spent the next week in hard work, anticipating the mill with Earl. ham at Richmond. Earlham, with a heavier team, was unable to gain on line plays, and both teams resorted to aerial attack. We managed to give Earlham the scare of their lives, and lost by a 7 to 14 score.

Going next to Rio Grande, a game fight was put up, with the scoring ad. vantage on our side at the end of the first half. Rio Grande, however, came out victors.

A good showing was made at Ashland, against the team that shut out Day,

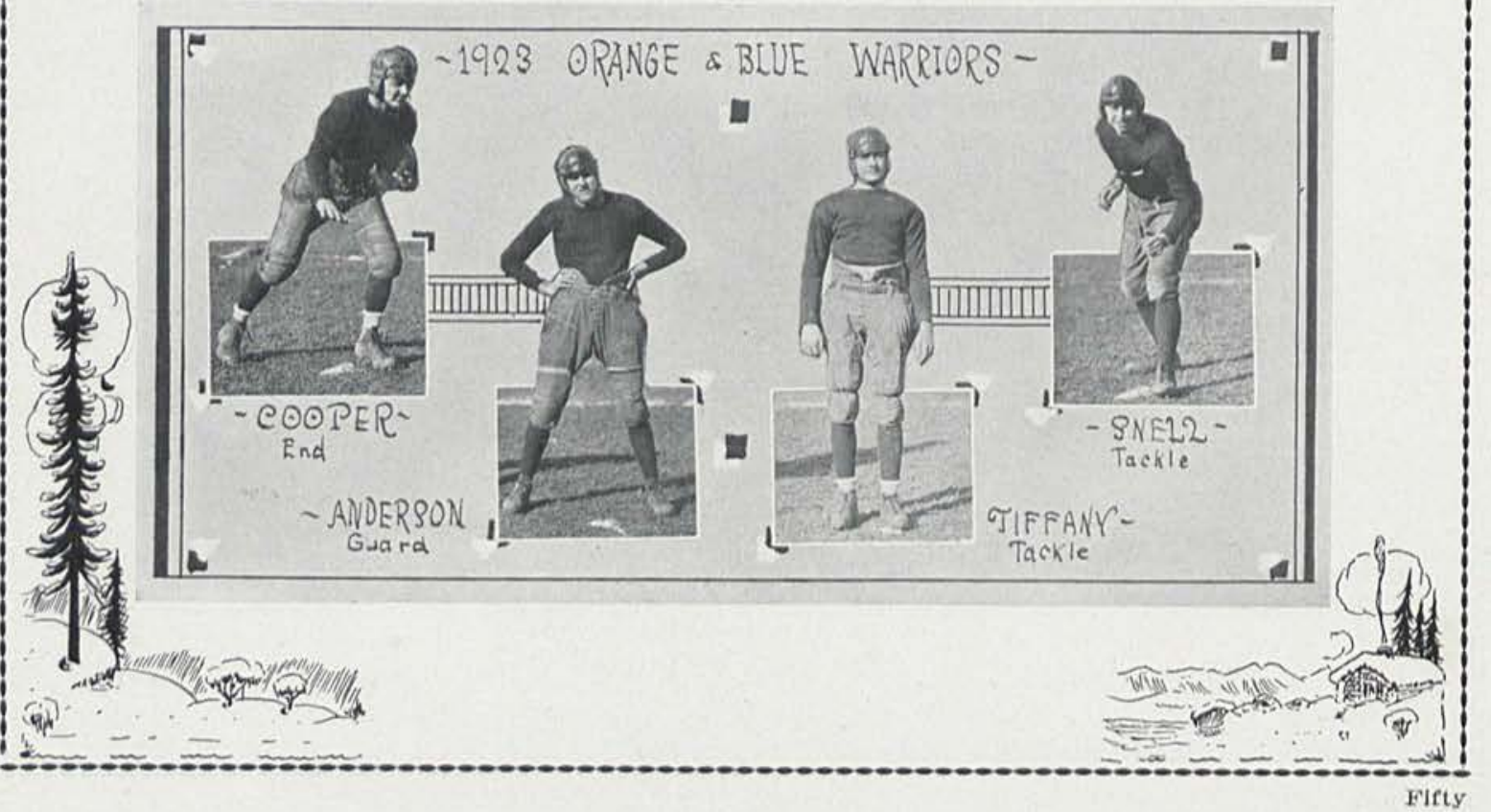




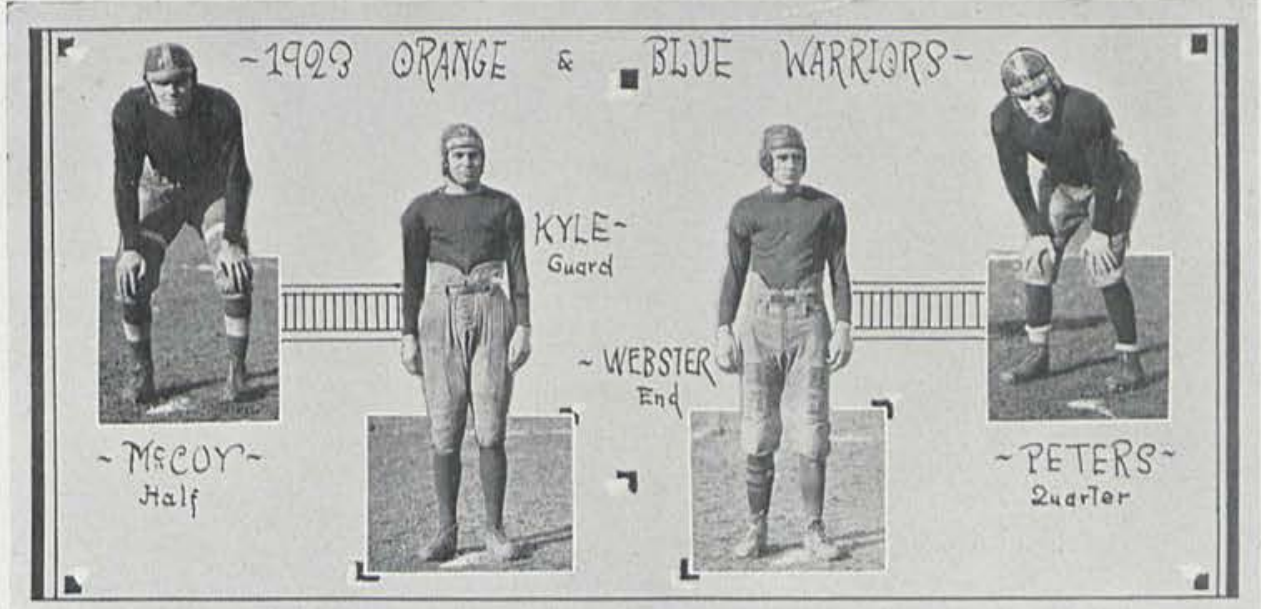

ton University. Weight and speed seemed to favor Ashland. Antioch was taught several pointers when they played the home game. At Capitol the team came out of their trance the third quarter and played football, but were unable to beat Capitol.

The season has taught us very forcibly, that a winning team cannot be placed on the field without co-operation, hard work, and skill. The latter will usually care for itself if the other two requisites are emphasized enough, not by a few but by all. No team however good, can play football without being in absolutely perfect physical condition. This condition is best fostered by keeping training rules.

While not winning a majority of games, football in Cedarville College in 1923 was a success, for success is counted, not in the number of games won, or in score alone, but in growth of spirit, in the good to the individual, and in the good to the college as a whole. Let's make 1924 a banner football year! It can be done!

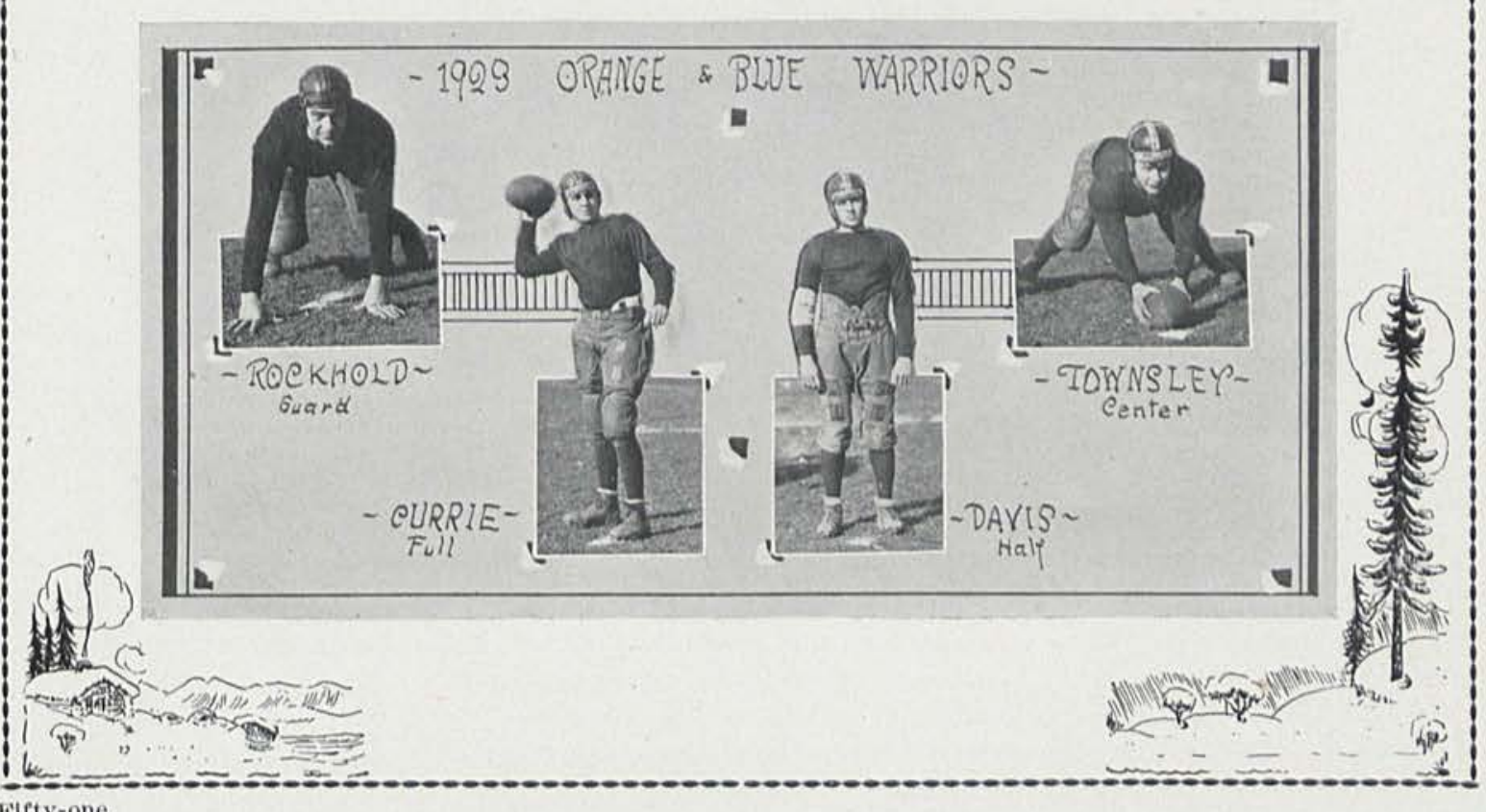


The CEDRUS 1924

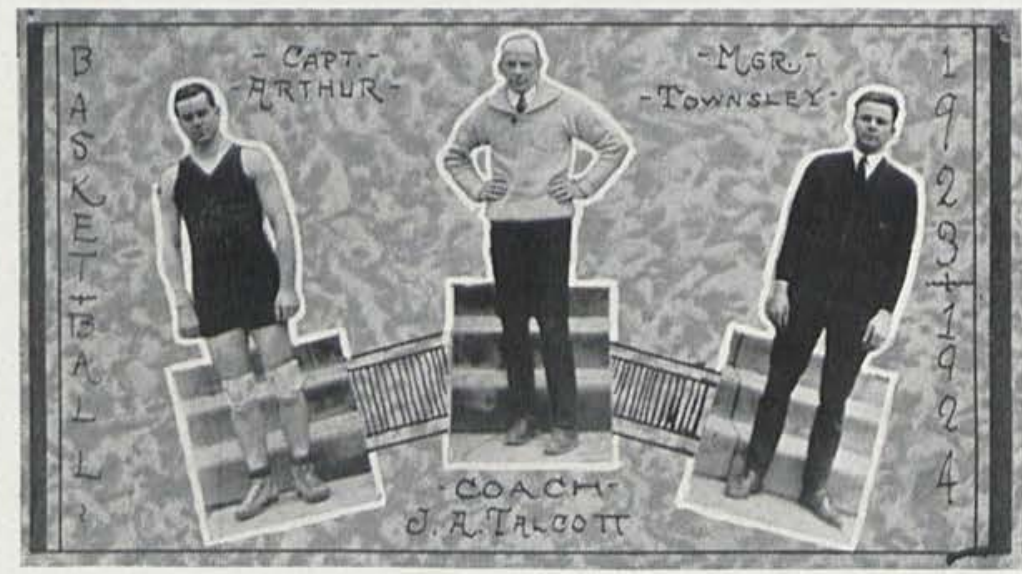

\section{Boys' Basket Ba 11}

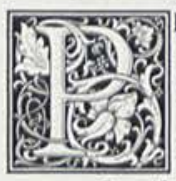

LAYING a brand of ball unsurpassed at times by none; yet failing at other times to work as an organized unit, this year's Basket Ball Team passes into history. We have made a name for ourselves, outdoing many previous teams in some respects, although losing several games in our schedule. "A good beginning makes a bad ending," is the popular saying but let us wait and see.

On the 6th of December our boys met Springfield Business College on the local court, and won the opening game of the season by a decisive score. Though yet in the early stages of development our players showed ability and the promise of being a winning team. The following Tuesday we journeyed to Sabina and in the last minute of play we were still leading by one point. The ball was still in the air as the final whistle sounded, only to drop through our opponents' basket on its downward swoop. This was bitter but the luck was against us so we made the best of the bargain we were able. The week-end was spent in Columbus. During this time we dropped two games; one to Capitol University, another to Bliss Business College. These were exceedingly fast teams so we did not let the defeats worry us.

Following this, we met the more experienced quintette from Wilmington College on the home floor. Our team played a good game in the first half but they weakened in the last part of the game. During our Christmas vacation, when we were feeling fine after receiving our gifts, we met the team from Defiance College and vanquished them. The game was played on a neutral floor in Dayton. The game was one of the most spectacular of the season. Trailing by a score of 23 to 9 during the second half and then winning out in an overtime period furnishes a contest replete with thrills and surprises.

Following this game our team met with a series of five reverses. Webster was on the sick list for three weeks. The student body was in despair and we thought that some evil spirit was certainly following us, as we would lose by provoking scores. The Jinx was trailing us in the first half of the game we played at Antioch, we just couldn't hit the basket. The second half was a battle from start to finish, but the lead was too large to overcome. Wilmington, Bliss, Babbs, and Ashland each eaptured a game at our expense.

We failed to live up to the adage quoted in the beginning of this review for which we are very thankful. The first victim of our rejuvenated team was Babbs from Xenia. The one to follow was the Y. M. C. A. aggregation from Washington. By this time we were again encouraged, and as the last game of the season rolled around we hoped to beat our old rival-Antioch. At last the evening came and we went to the Gym hoping against hope that the score would be large for us. By the time the boys game was called the enthusiasm of the crowd was unsurpassed. The game started
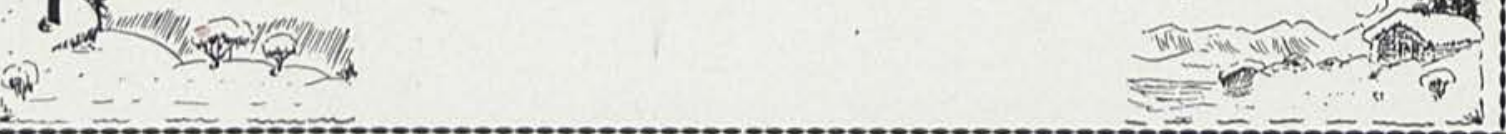


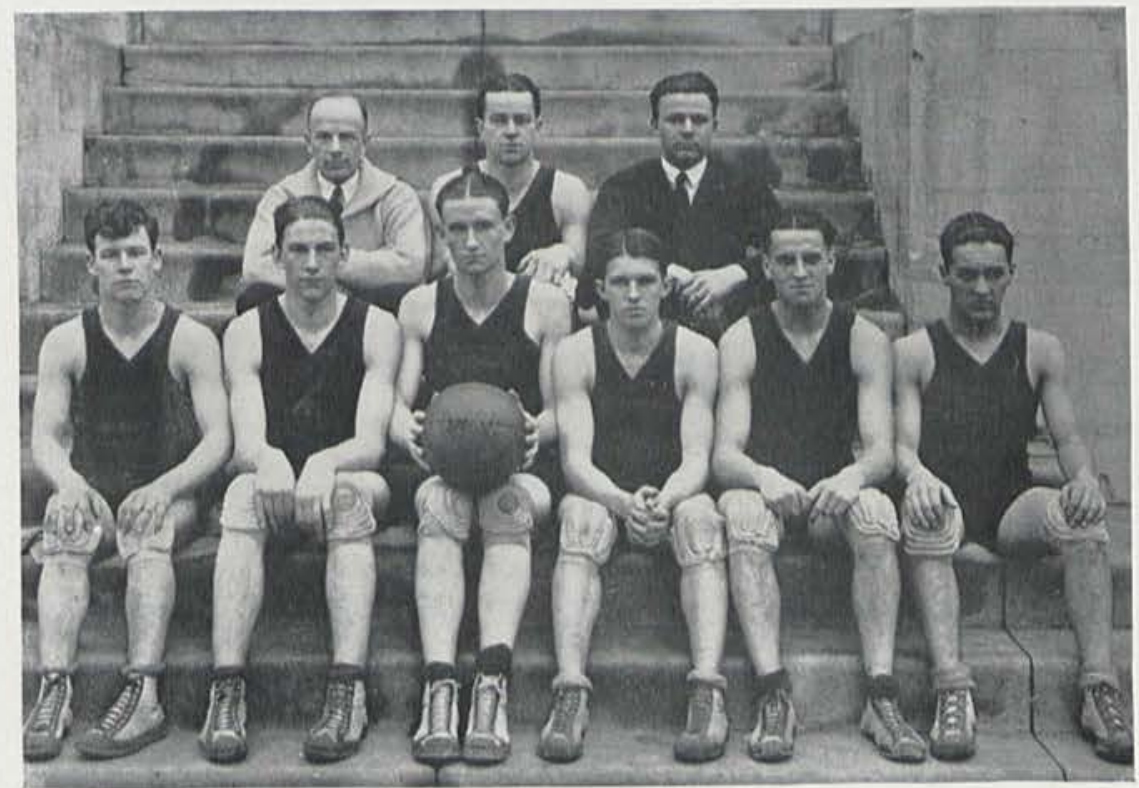

MEN'S FIRST TEAM

off in Antioch's favor but about the middle of the first half our boys began to find the basket and for the remainder of the game we fought as never before and the game ended with the score 19 to 17 in favor of Cedarville.

With such an ending of the season the hopes for a good team next year are high. Let us make the year to come one of the most successful in the history of Cedarville College.

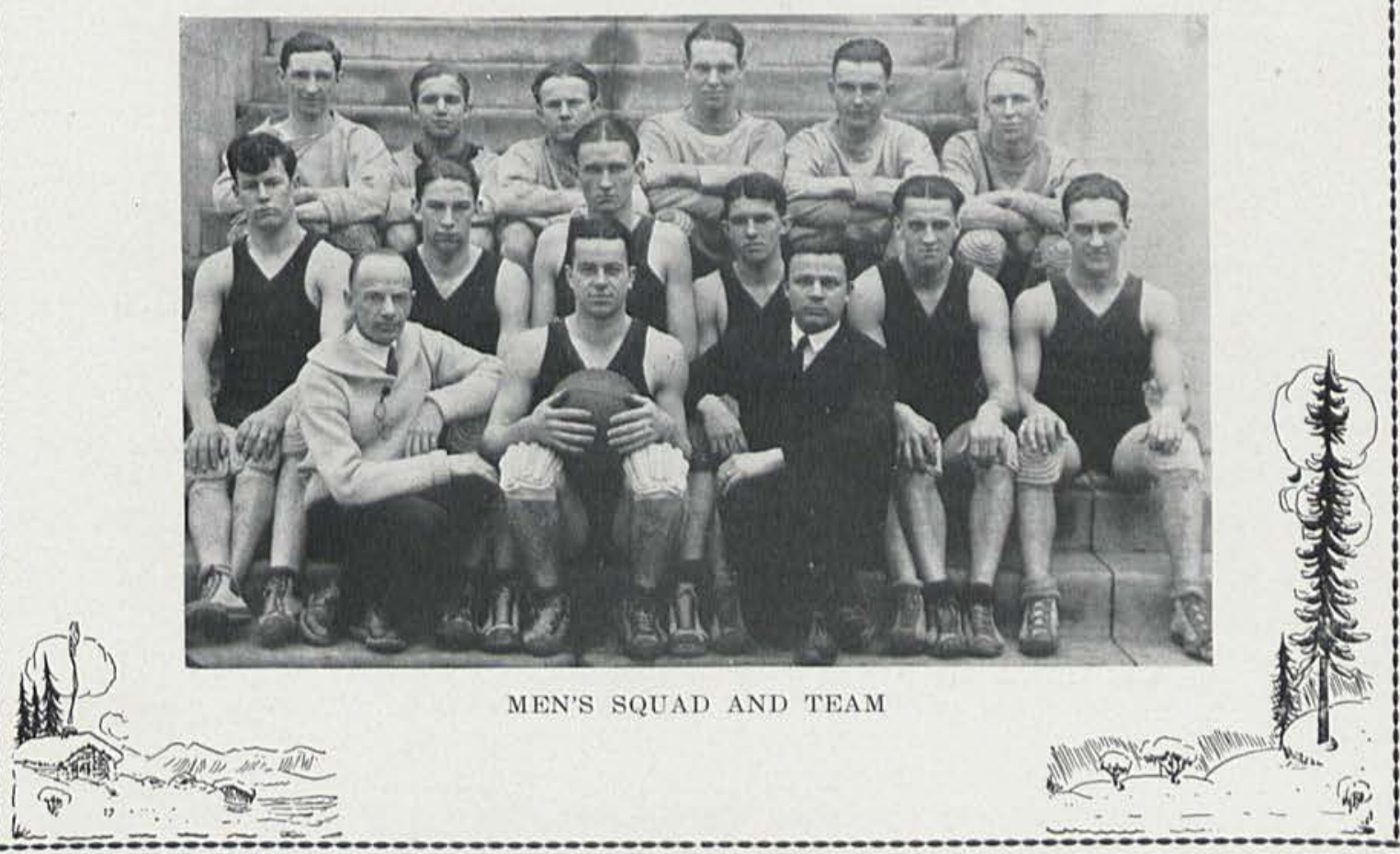

Fifty-three 


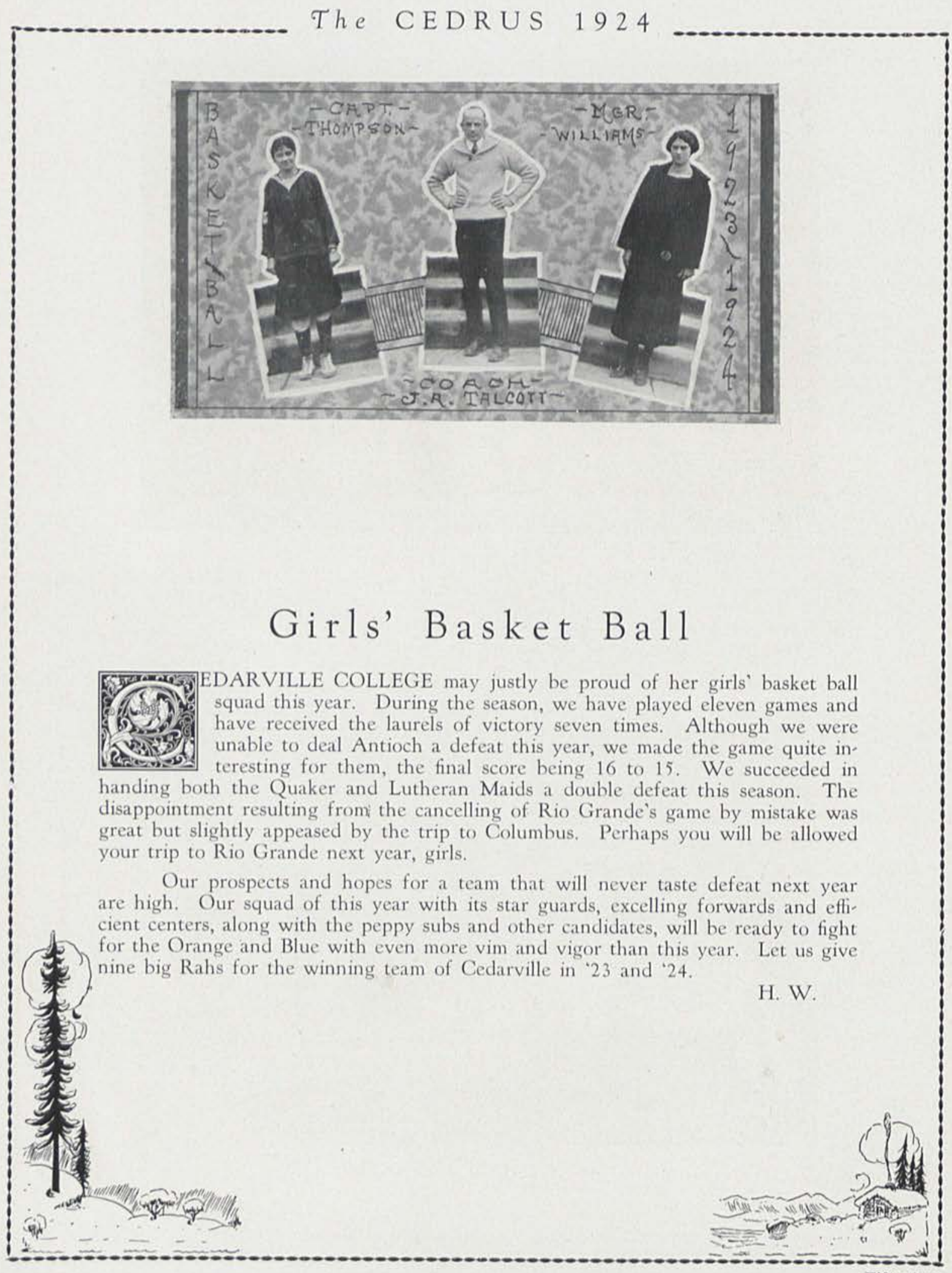

Fifty-four 
The CEDRUS 1924

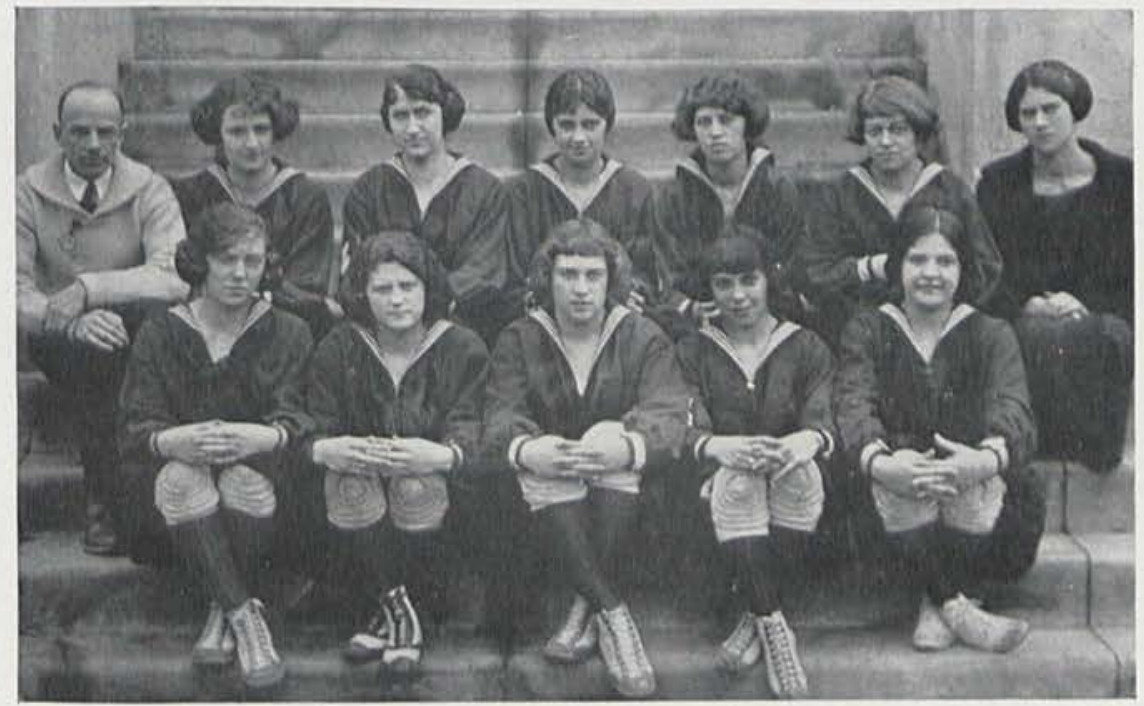

GIRLS SQUAD AND TEAM

GAMES AND SCORES

Springfield Business College

Springfield Y. W. C. A.

Wilmington College

Wilmington College

Bliss Business College

Antioch College

Grandview H. S.

Springfield Y. W. C, A.

Wittenberg College

Antioch College

Wittenberg College
7

18

15

9

15

26.

25

13

8.

16

9.

Total
Cedarville 31

Cedarville 9

Cedarville 16

Cedarville 15

Cedarville 22

Cedarville 11

Cedarville 6

Cedarville 17

Cedarville 14

Cedarville 15

Cedarville 14

Total

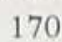

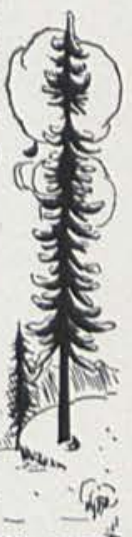


The CEDRUS 1924

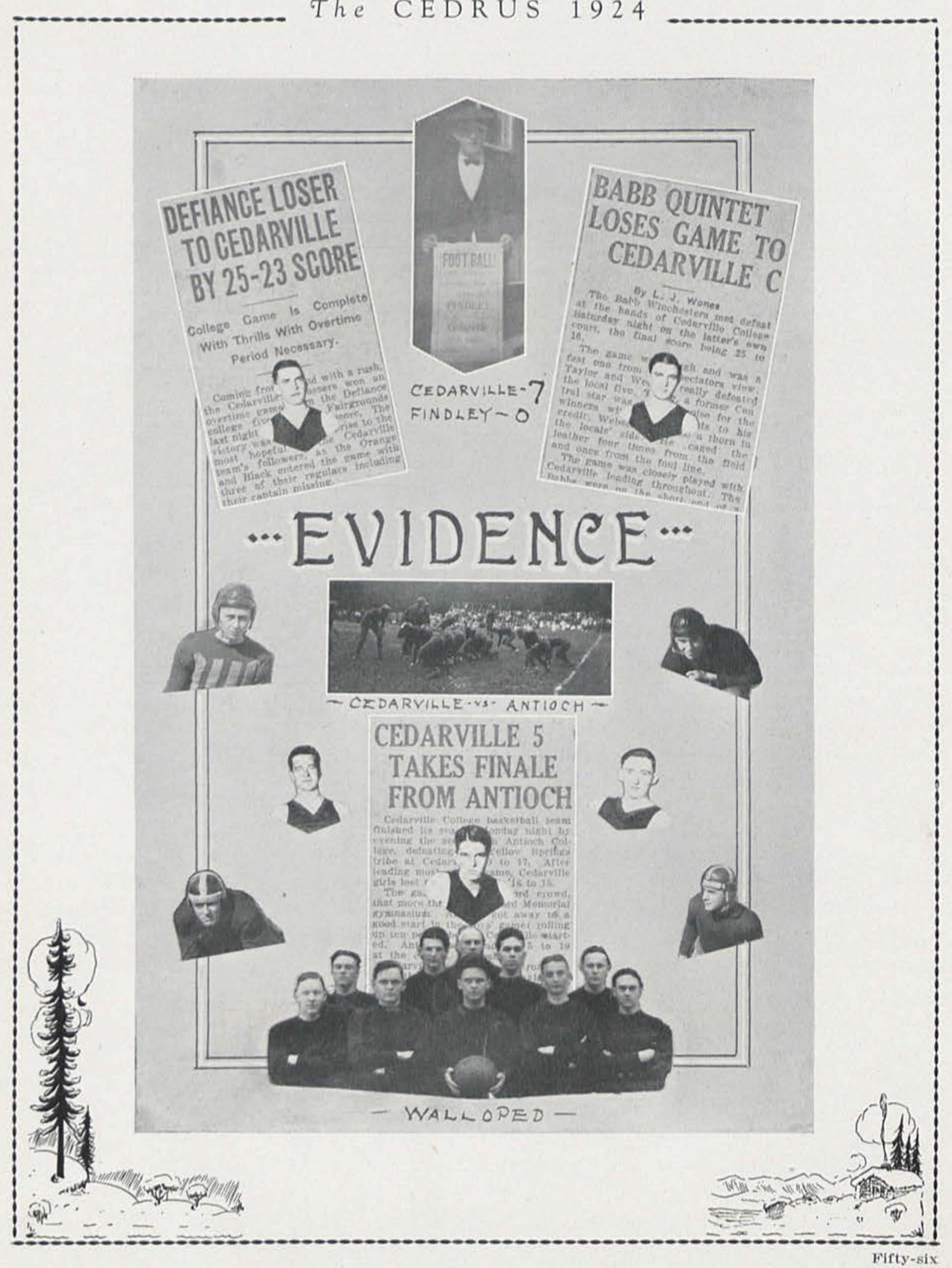




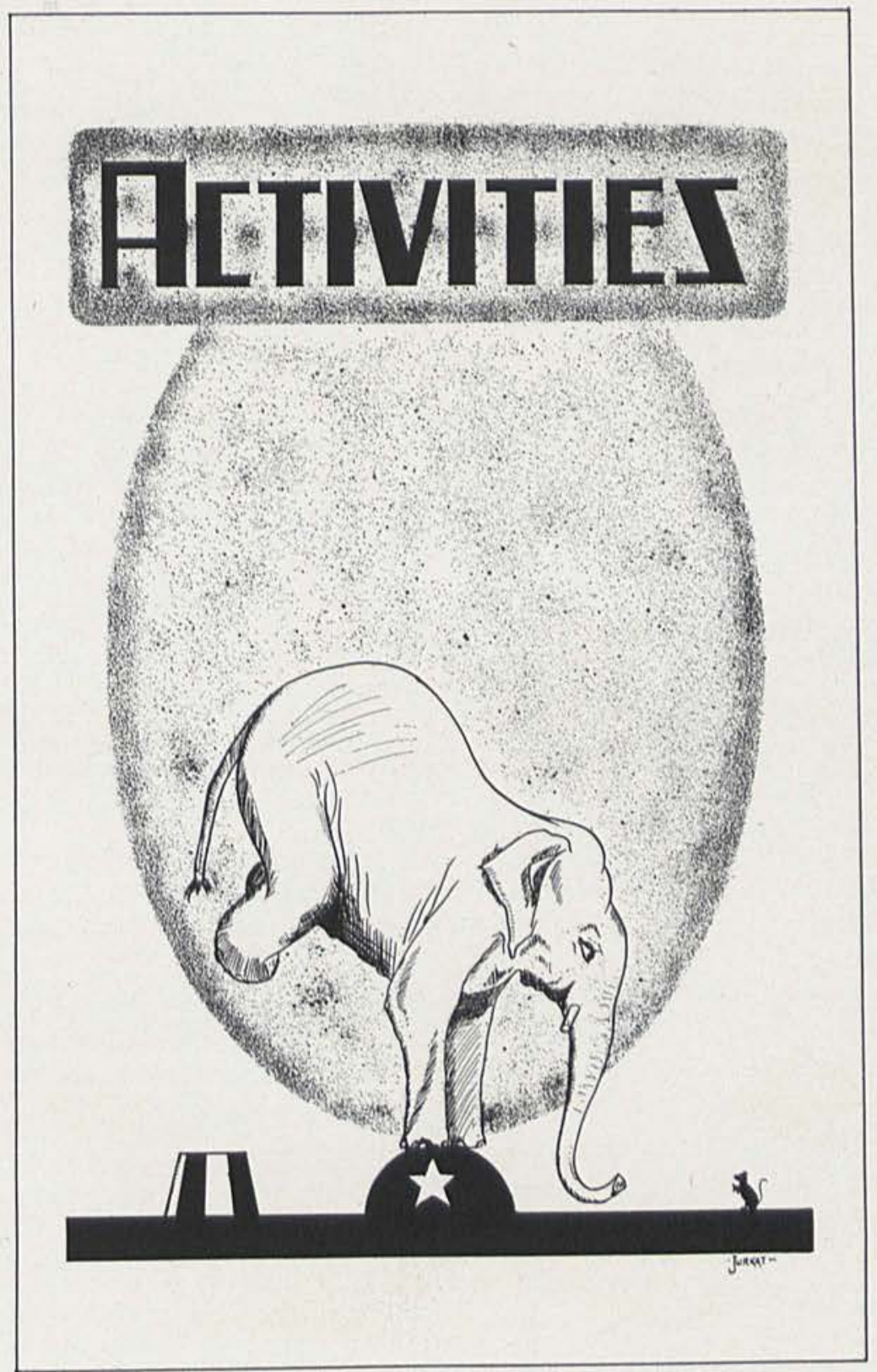




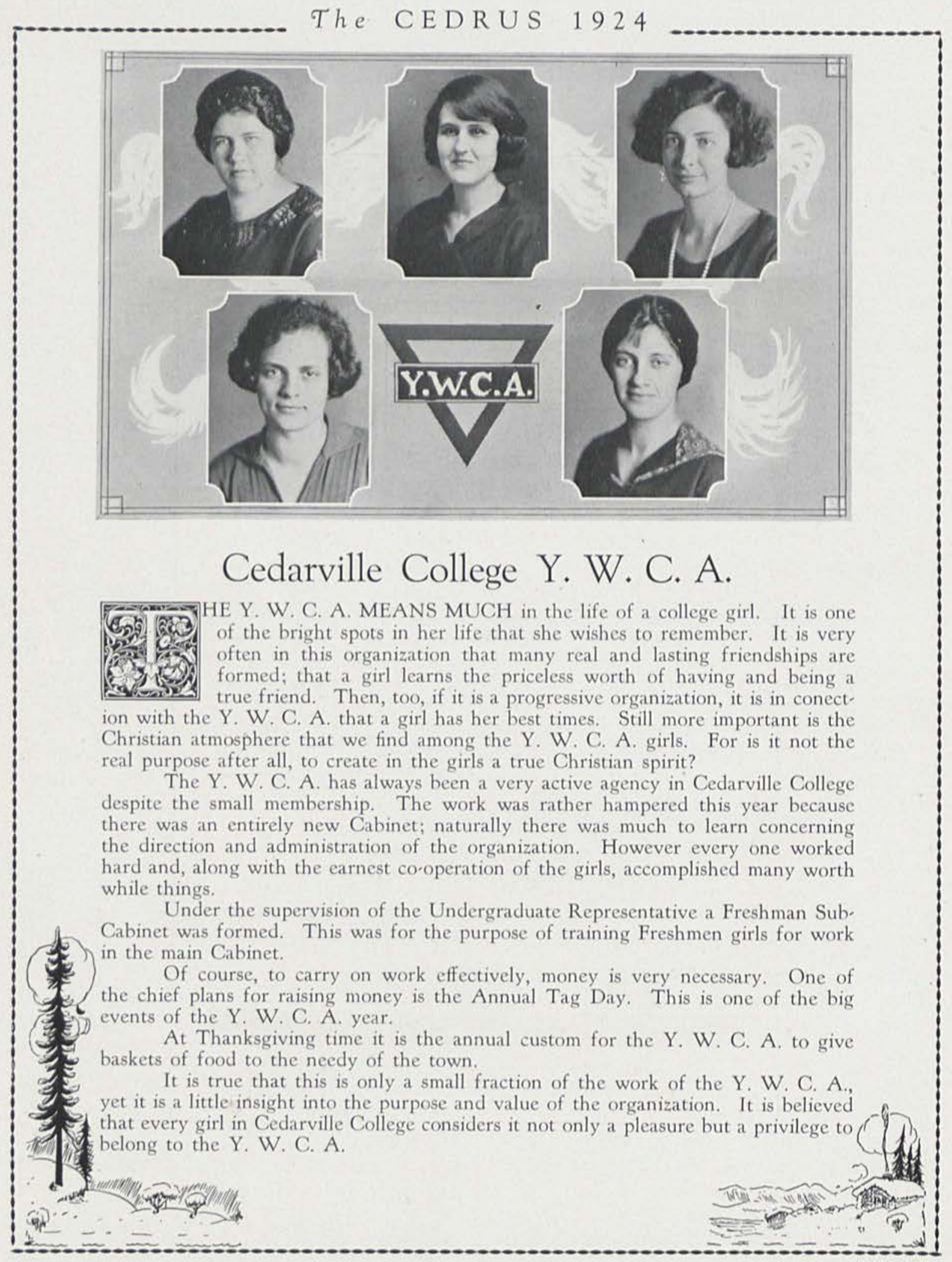

Fifty-eight 


\section{The CEDRUS 1924}

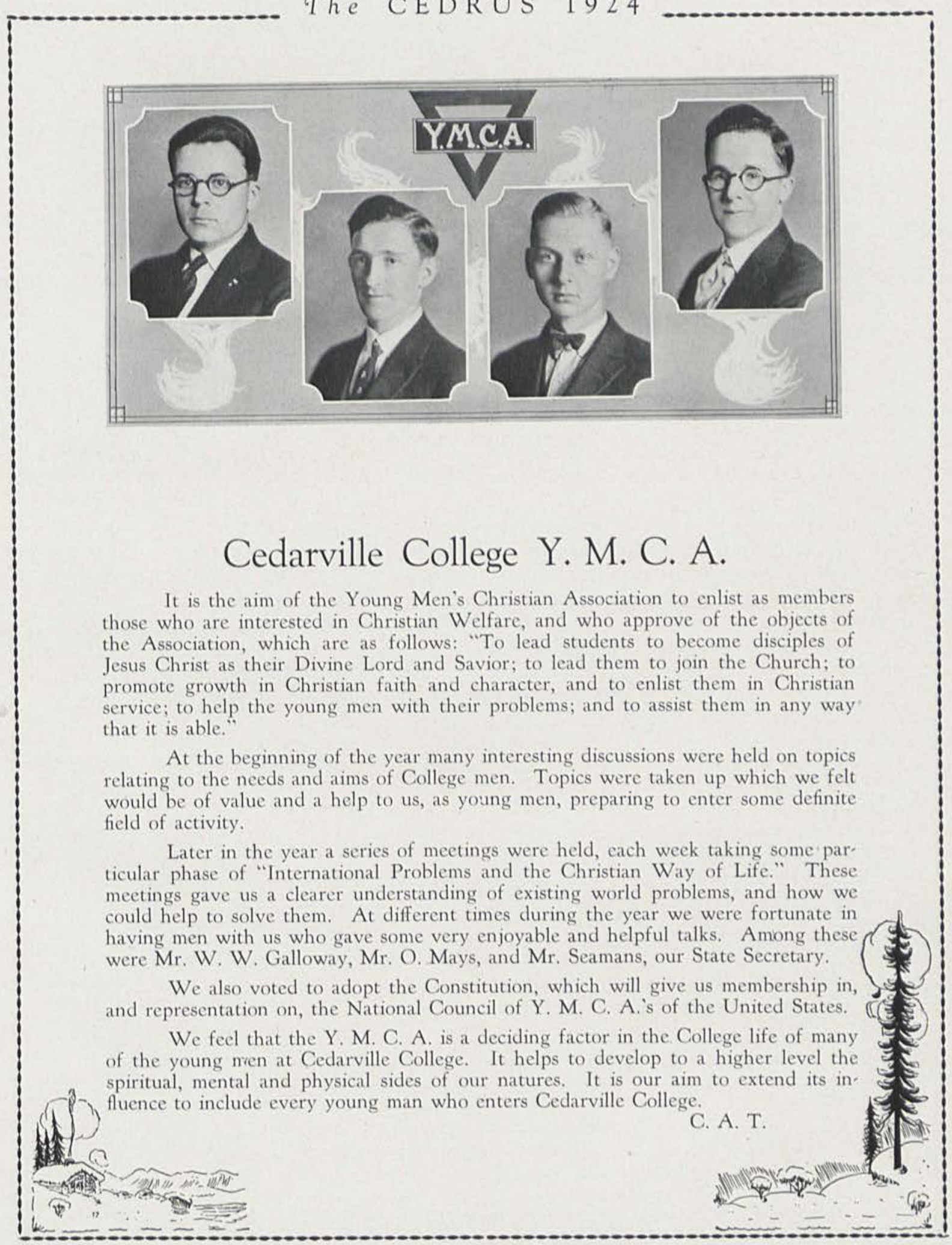

Fifty-nine 
The CEDRUS 1924

\section{The College Club}

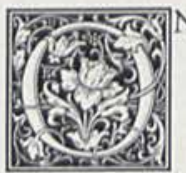

NE OF THE CHIEF CENTERS of attraction at Cedarville College is the College Club located in the basement of the library. Here it is that the thoughts of many of our students fondly linger, for it is our eating house and has an irresistable fascination for some. Every day a noisy, ravenous crowd gathers below the library and waits for the bell which sounds the signal for a rush to the dining room. Around the tables we learn to know each other well, for under the influence of plenty of good food the bars of reserve are lowered and the true disposition shows forth.

A discreet exercise of the powers of observation reveals some truly startling things, and we are quite confident that we have discovered a sufficient cause for the excess of corpulence which some of our members so loudly bewail. The devoted couples who eat together day after day are another source of interest.

After careful consideration we have come to the conclusion that the looks of consternation on the faces of certain of our young men are produced by the alarm. ing prospect of the amount of foodstuffs he may have to buy in the near future. On the other hand, we have been confidentially informed that these same young men have caused great alarm because of the great quantity of food they devour.

Of course there are times when the crowd gets hilarious and even the shy become rash. Then it is that some unsuspecting person may be startled by the sight of his food swimming in a pool of water-an unsolicited contribution from a near neighbor. Naturally a lot of joking and teasing go on while we eat, but most of us have learned, and experience has taught us, to enter into the fun and contrib. ute some ourselvés.

However we do not become unmanagable, for we realize that college attend. ance should impart some sort of dignity and, moreover, several members of the faculty eat with us to restrain us, if necessary, from behaving like the Goops.

This whole year long we have enjoyed ourselves at the Club, and we'll long remember the place where we ate, drank and were merry.

H. S. and E. B. 
The CEDRUS 1924

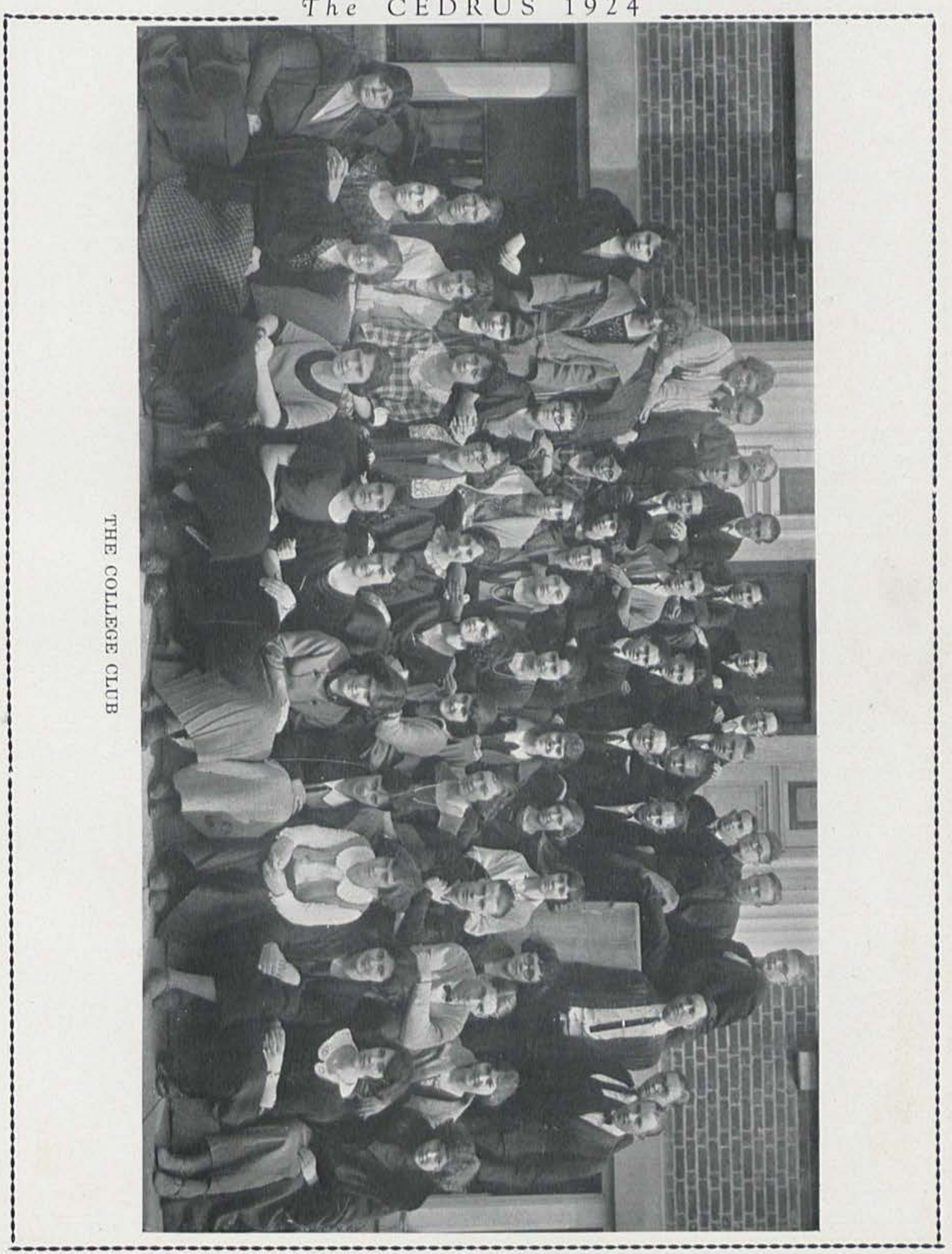

Sixty-one 


\section{The CEDRUS 1924}

\section{The Staff}

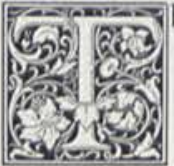

HE TASK OF COMPILING A BOOK of this type is not one that can be grasped in a short time; we ask you not to judge us severely as the officers of The Cedrus were new at the work. It was your Editors' desire to produce a book as worthy of Cedarville College as we could your approval. make. We submit the finished product and hope that it will meet with

The Cedrus has had a hard and stormy journey this winter and on several occasions we were unable to see our path but we always received aid when affairs looked the darkest. The Staff desires to thank those merchants who were loyal during the past year in their support of The Cedrus; we also wish to express our appreciation for the aid given by the Hagar Paper Co. through their General Manager, Mr. Wilson Galloway. We are also pleased to express our thanks to all who had a part in making The Cedrus Play a success.

We feel that you will grow more and more attached to your Cedrus as the years pass by. It will give the Staff great satisfaction if we can help foster in you a love for your Alma Mater in future years, and it is our sincerest hope that this book may bring you happy memories of your year in Cedarville College.

The Editor
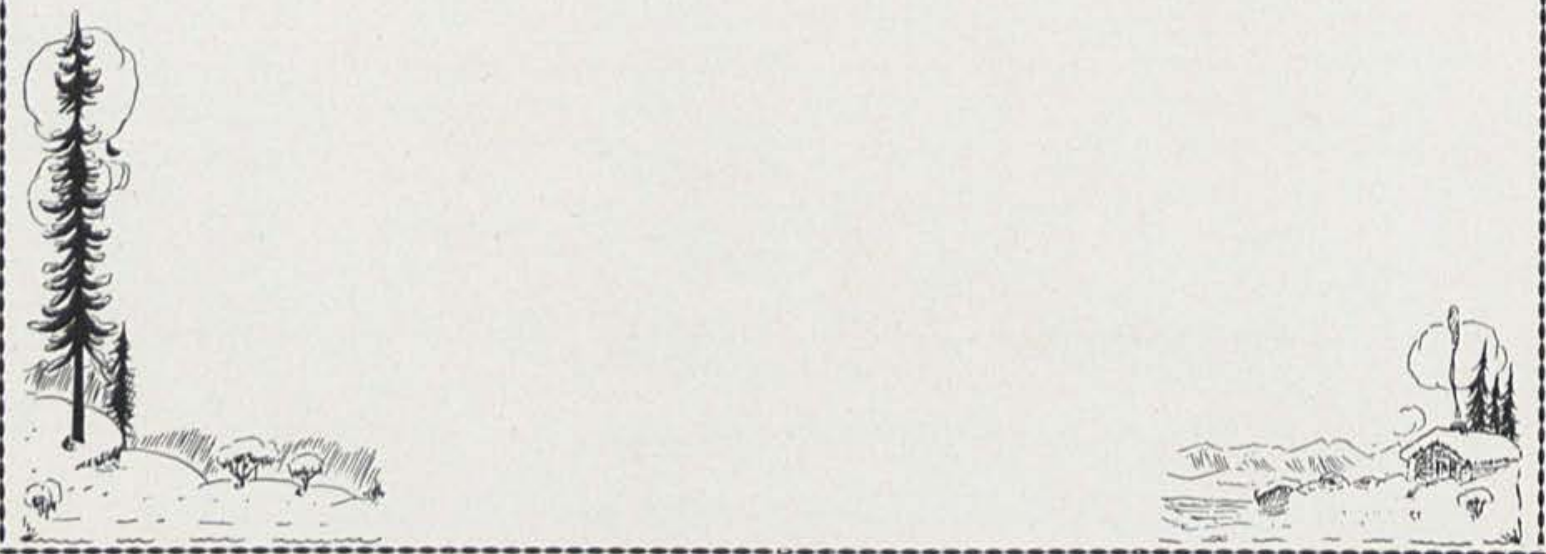

Sixty-two 
The CEDRUS 1924

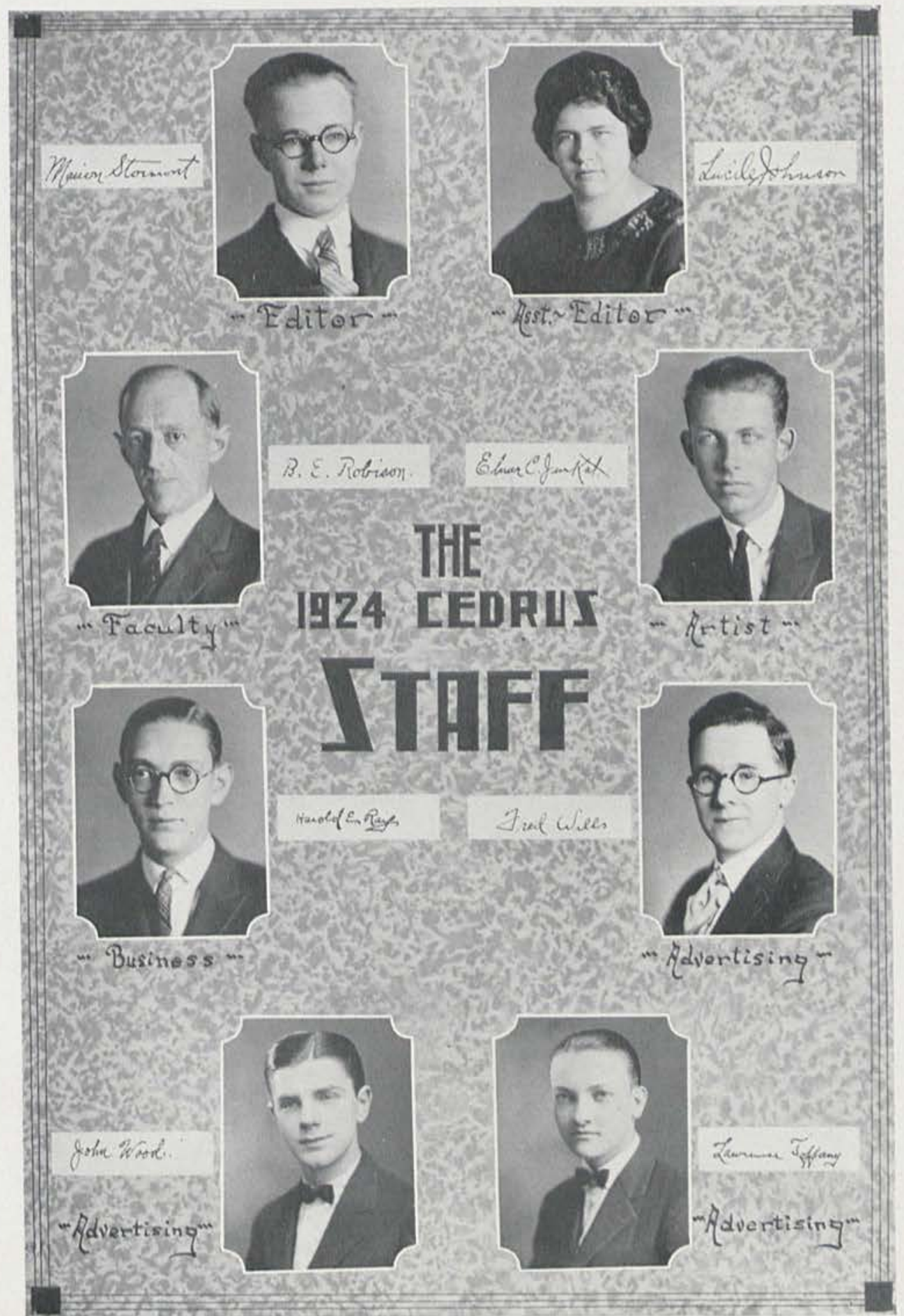


The CEDRUS 1924

\section{The Philadelphian Literary Society}

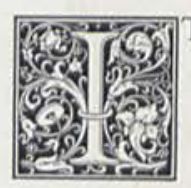

T WAS ON THE OCCASION of a visit to his Alma Mater that an alumnus of Cedarville College encountered one of its present students. After the usual inquiries into the work of the college, he spoke reminescently of the Philadelphian Literary Society as it existed when he was a member.

He told how this society, the first in Cedarville College, was organized in 1894. The organizers were a band of energetic students who showed unflagging interest and determined devotion. They selected the name "Philadelphian" with "Philo" for short. The motto adopted was: "With Malice toward None and Chare ity for All," and the society colors were "Black and Old Gold." After the College was established in the new building the Philos furnished the larger of the two society halls. About this time there were some slight differences among the members which resulted in the formation of a second society. The alumnus further manifested his interest by saying that he had kept in touch with the work of the society after he left college. He was very sorry to learn of its discontinuance because grad. uates have gone forth from Philo Hall who have won respect and honor wherever they have gone.

The student to whom he was talking gave this pleasing bit of information. Last year the students of Cedarville College were divided into two literary societies, namely: No. One and No. Two. Last fall at the opening of college society No. Two began its campaign, and as a result the records show that we have seventy-eight enrolled. The first question to be considered was a name for the society. After much discussion and investigation the name "Philadelphian" was adopted because of the work that the former society of that name had accomplished. The new society has taken possession of the old Philo Hall and adopted its colors. A constitution has been drawn up and adopted and the motto to be upheld is "Read and think, know and be wise." There is a true spirit of enthusiasm and co-operation manifested which must endure and increase as the years pass, and the name, the work, and significance of Philadelphian is handed down from student body to student body.

'Flourish, prosper may thou ever,

Loved and honored be thou still!

Tho' some ties we all must sever,

In our hearts we keep the will.

In the years that are before,

May countless trace their fortune back

To the name they now adore,

Written in the Gold and Black."

June Thompson 
The CEDRUS 1924

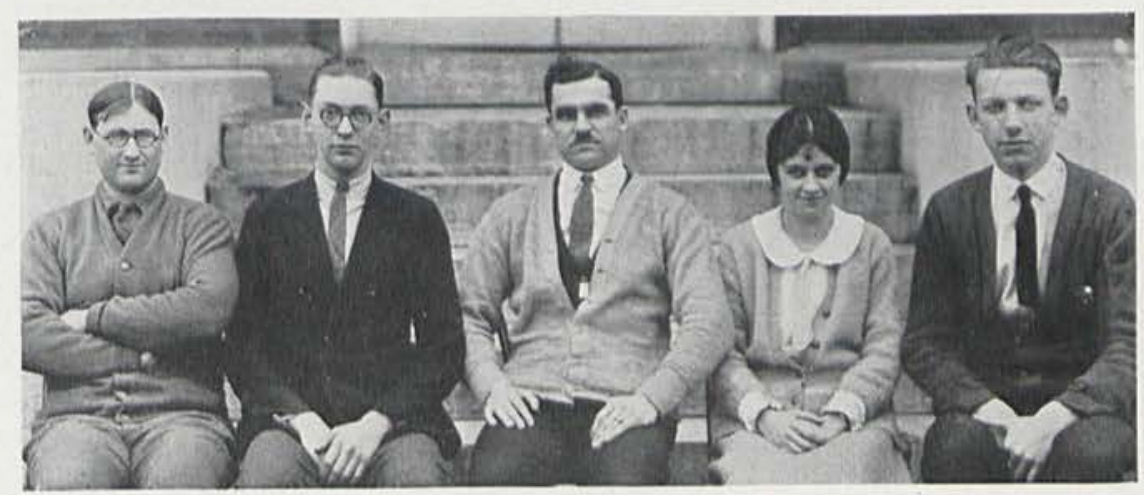

PHILADELPHIAN OFFICERS

President, G. L. Markłe

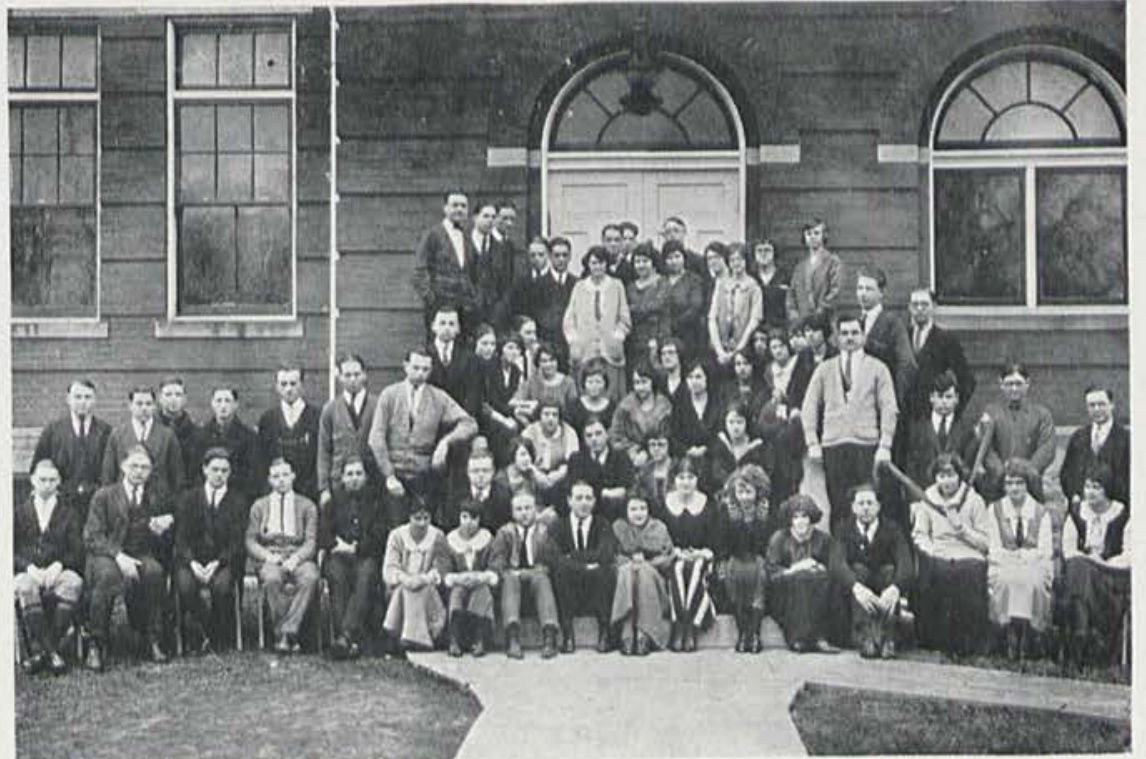

$i$ क 17 . 
The CEDRUS 1924

\section{Philosophic Literary Society}

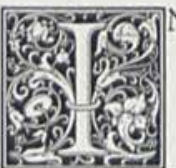

THE FALL OF '95 a few of the energetic students realizing the advantages to be derived from the organization of a second literary socieiy, because of the greater college spirit it might develop through rivalry and competition, accordingly called a meeting of all interested in the movement. The first meeting was held at the home of Miss Anna Orr, and the name chosen for this new organization was the Philosophic Literary Society. Beginning with Jan. 6, 1896, meetings were held weekly in the College Chapel, until in December of "96 the Philosophic Hall (now the office) was elaborately furnished and decorated in the society's colors, "Green and White." In 1908 the faculty took control of the society until 1916, due to the ill feelings aroused. Throughout this time the society continued to prosper.

However, during the late war the membership lessened and because of this and other reasons it was thought advisable to disband. In 1919 the Philosophic together with the Philadelphian society were fused into one, which took the name "Orange and Blue,"

Before the close of College last spring we decided to once more reinstate the literary societies in our college (although the names Philosophic and Philadelph. ian were not decided upon until this fall). Numbers one and two were drawn by the students and in this way the societies were equally divided. With the coming of the Freshmen in September quite a number of new names were added to our roll. Why did they not all join? Because they did not have the essential qualifications so we would not have them. Only the beautiful, the brilliant, the best in every line became Philosophics.

So it has been in the past year of the society; so may it be to the end. Let each Philosophic keep strongly in mind that the end and aim of his society is culture and cultivation. Let him remember that time and-money given for the honor of Philosophics will yield no small returns in benefit to humanity, and may each one keep ever before him the Philosophic motto

$$
\text { "Be perpetual always." }
$$

D. Oglesbee
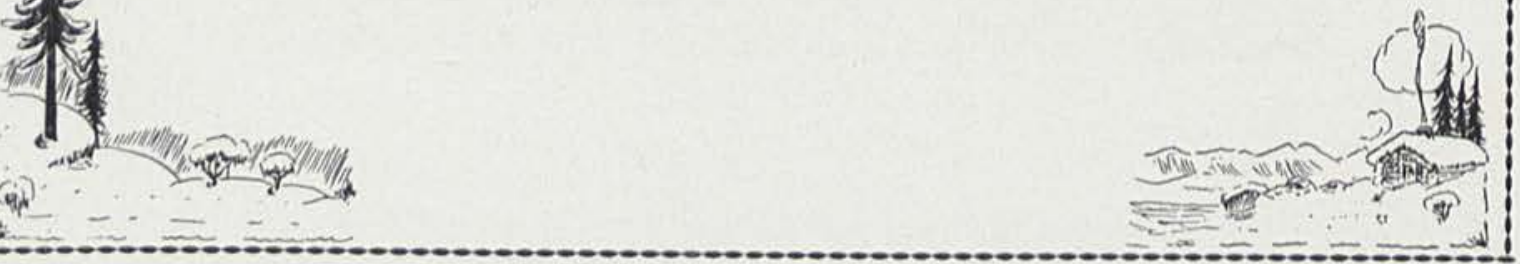

Sixty-six 
The CEDRUS 1924

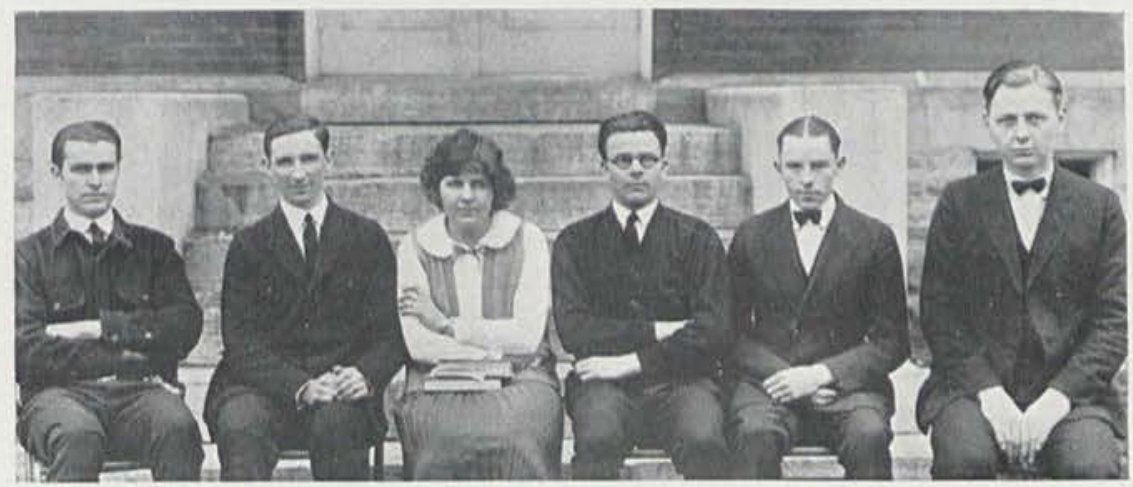

PHILOSOPHIC OFFICERS

President, Charles Townsley

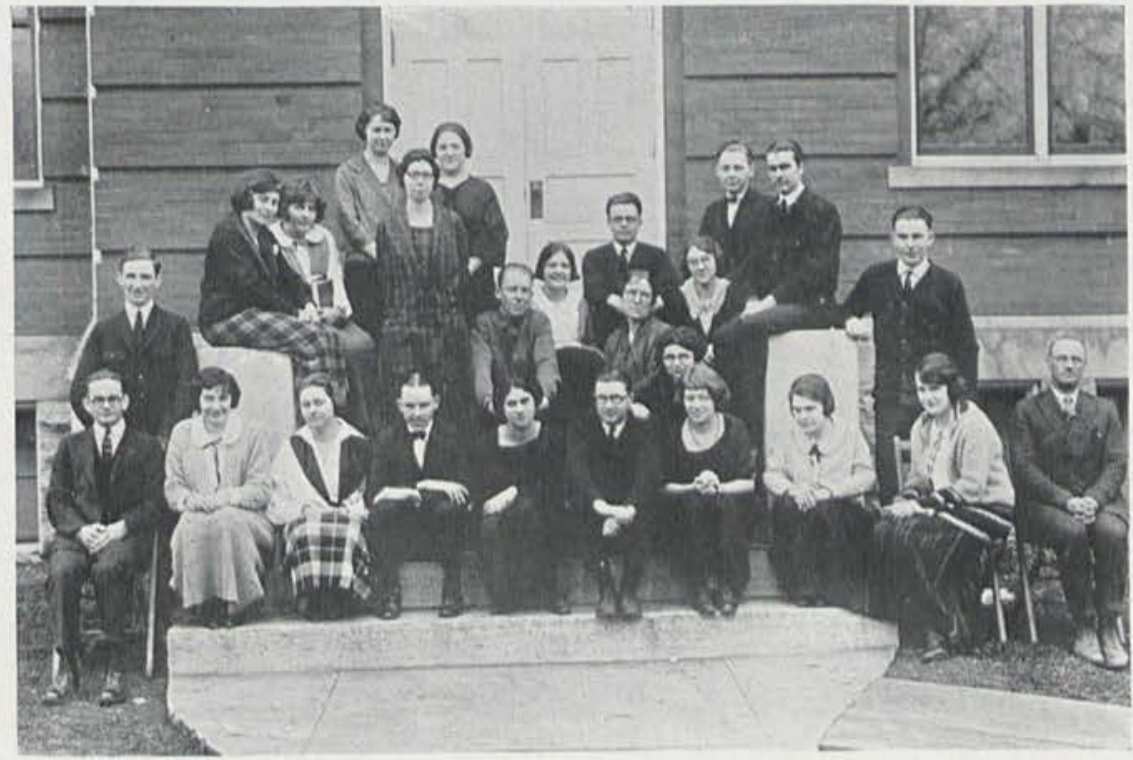




\section{The CEDRUS 1924}

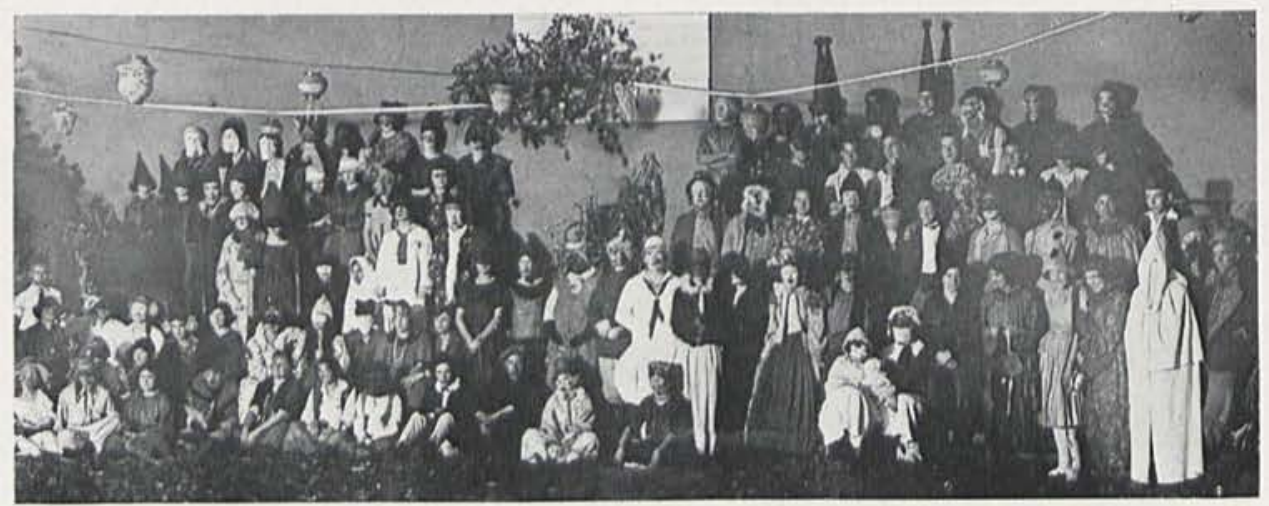

\section{The Halloween Party}

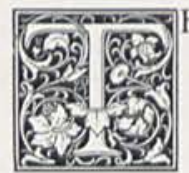

HIS IS AN ANNUAL PARTY given one year by the Y. M. C. A. and the following year by the Y.W. C. A. This year the girls were entertained by the boys at a masquerade ball held in the Gym. Many funny and interesting persons were present, and a prize was given to the best character represented. Mr. Donald Wickerham, dressed as a woman, and pushing his wife in a small doll buggy, kept the crowd guessing who they were and rightfully won the prize. Before the crowd unmasked a flash-light picture was taken which was very good.

Many interesting games were played and two gypsies were there to tell fortunes. While all sat frightened in the dark, Mr. Markle told a most interesting ghost story, which was vividly illustrated.

Delicious and bountiful refreshments were served with pre-Volstead cider always at hand. After spending a very enjoyable evening we repaired to our homes at an hour within the limits of the faculty rule.

\section{The Girls' Banquet}

The lady members of the faculty decided that the girls of the College should be given a few lessons in etiquette. A committee was appointed with Miss Koehler as chairman, to plan our first lesson which was to be a six o'clock dinner served in the Community Hall. After much talking, trying to decide which evening gown we should wear, and after the committee had had a hot debate in deciding how to lay the silverware properly on the table, about sixty attended the banquet. A three course dinner was served in just the proper way and all ate with fear and trembling.

The out of town guests were Dr. Whitney, New York City; and Supt. and Mrs. Aultman, Xenia, Ohio. The affair was very successful and will long be re membered by the girls.
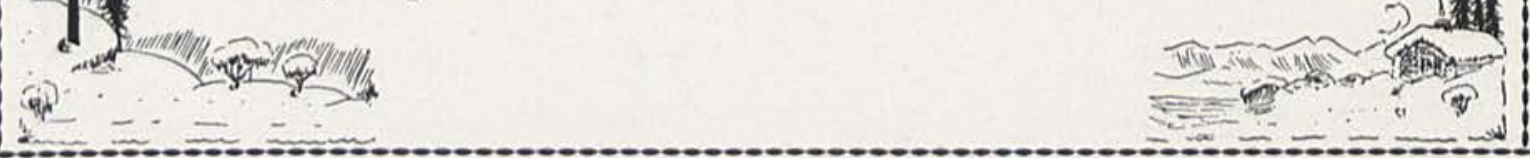

Sixty-eight 


\section{Church Reception s}

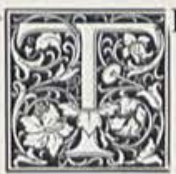

HE FIRST SOCIAL EVENT of the season was a reception given by the Christian Endeavor Society of the Reformed Presbyterian Church. This was given the first Friday after college began in order that the new students might be given a welcome, and that all might get acquainted. The girls wrote interesting descriptions of themselves, which were bought by the boys, Mr. Markle making an efficient auctioneer. In this way we secured our partners for supper. We went to the basement and while we ate many yells and songs were given by the various groups. After many games were played we went home, feeling that we had a finer crowd of students in Cedarville College than any year before.

Later in the year the students and faculty were entertained at a reception given by the Epworth League of the Methodist Church. By this time we had be. come so well acquainted that it was not difficult to plan an entertainment for the evening. Many old-fashioned games were played, such as Dusty Miller, Spinning the Pan, and Charades. A good supper was served. The crowd left at a late hour, and thus we had enjoyed another pleasant evening together.

\section{The Valentine Party}

On February 14th the students and faculty of Cedarville College were royally entertained by Dr. and Mrs. W. R. McChesney at their home on Xenia Avenue. Everything had been planned in keeping with St. Valentine's Day. The most interesting feature of the evening was the opening of a large valentine box which had been stuffed to overflowing by the students. This caused much amusement, because not all the valentines received were beautiful. Miss Somers and Dr. McChesney distributed the valentines.

Groups were chosen for supper in a very clever way and we wended our way to the dining room. A most delicious repast was served. Mr. Markle, who sat by the cupboard in the dining room, acted as assistant caterer. As soon as the first course had been served Markle reached into the cupboard and passed the mustard, followed by apple sauce, butter, cheese, horseradish, jelly and peach chop. We are not sure what would have been passed next, had Mrs. McChesney not appeared on the scene. After supper we sang old songs and spent an evening full of mirth and song. We left feeling that we had spent a very pleasant evening with our President and his family.

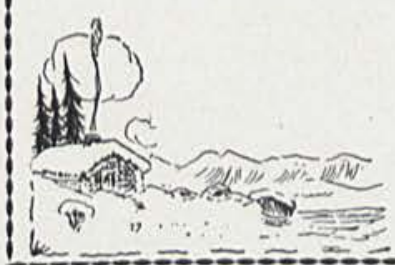

Sixty-nine 
The CEDRUS 1924

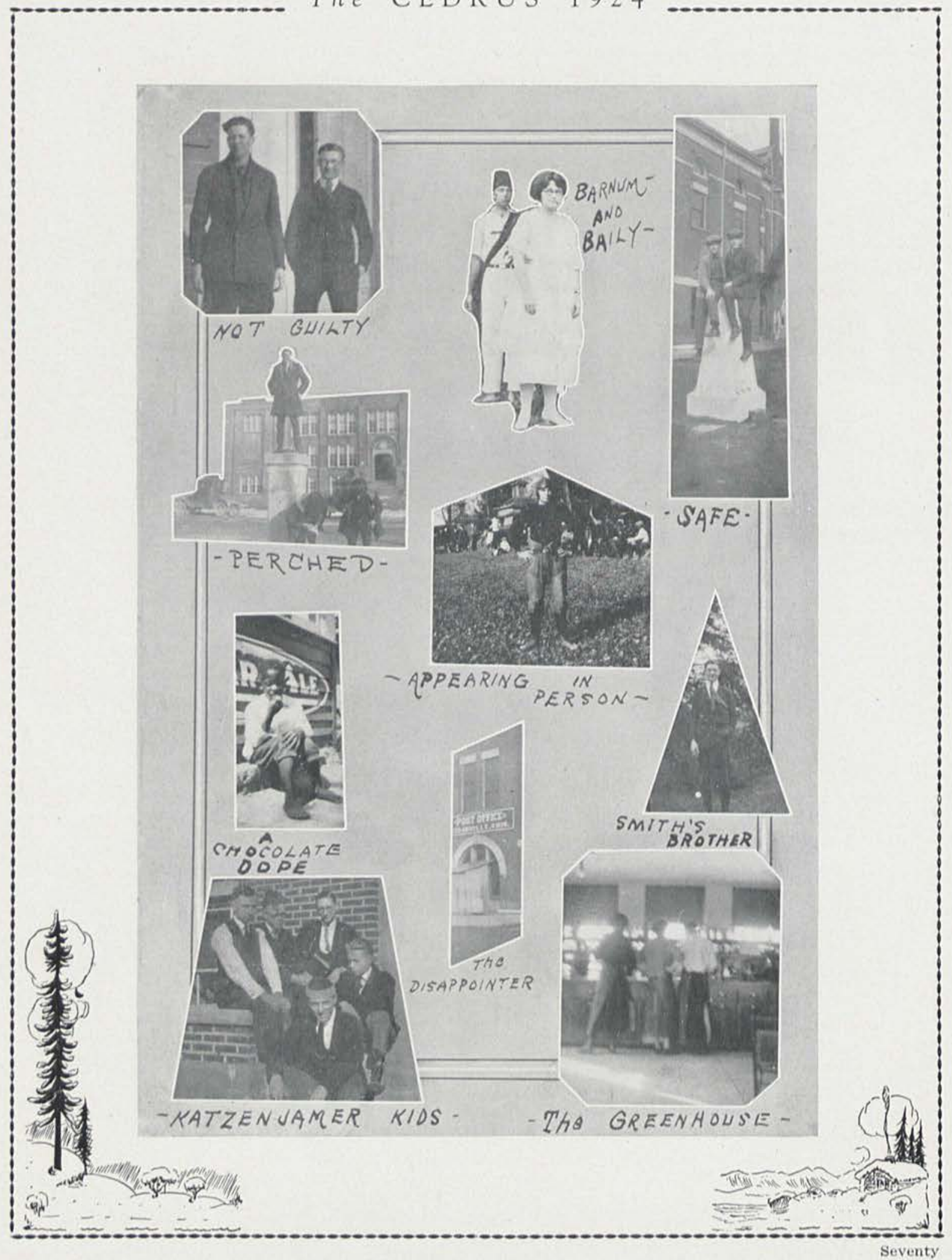


The CEDRUS 1924

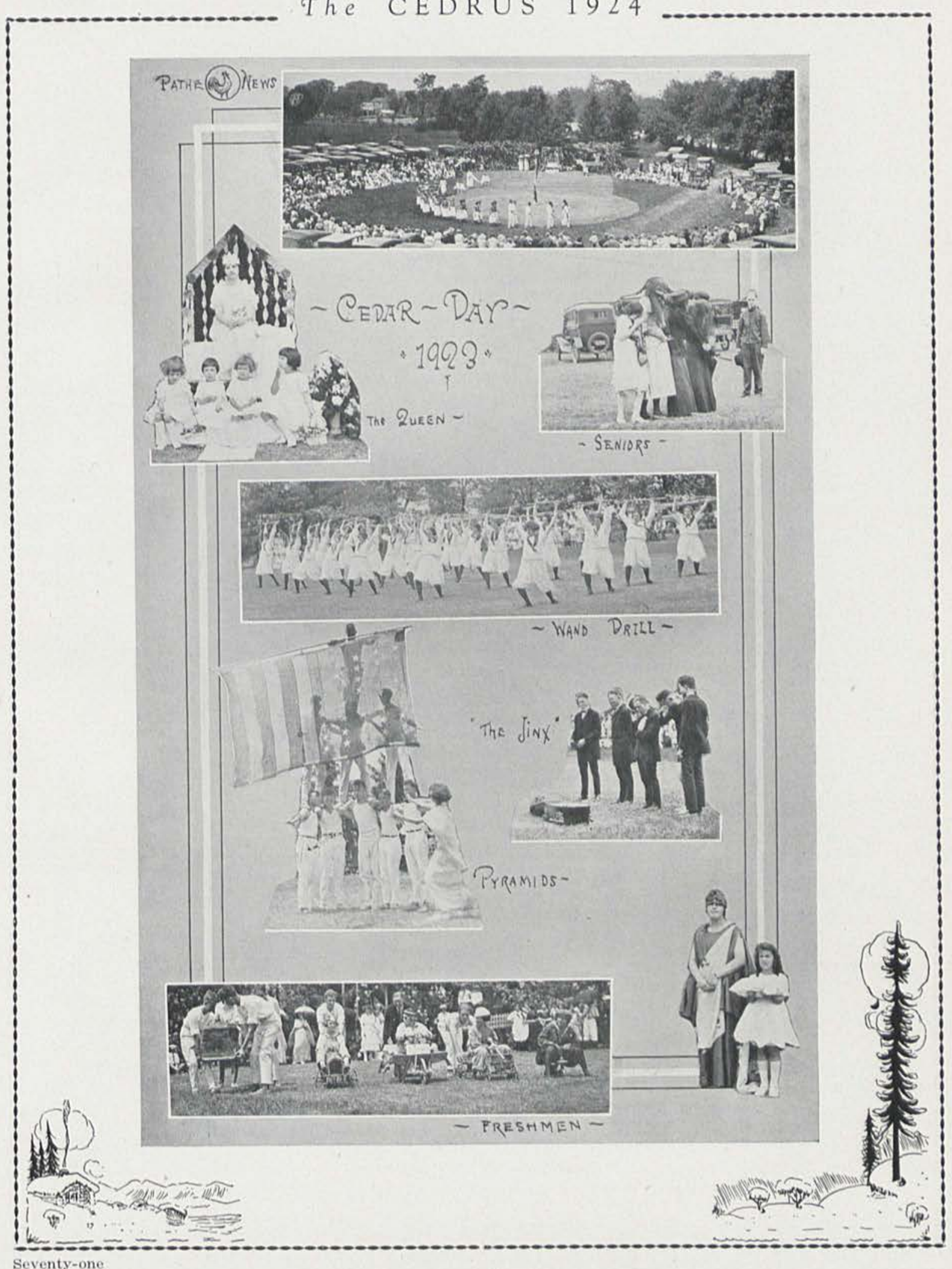




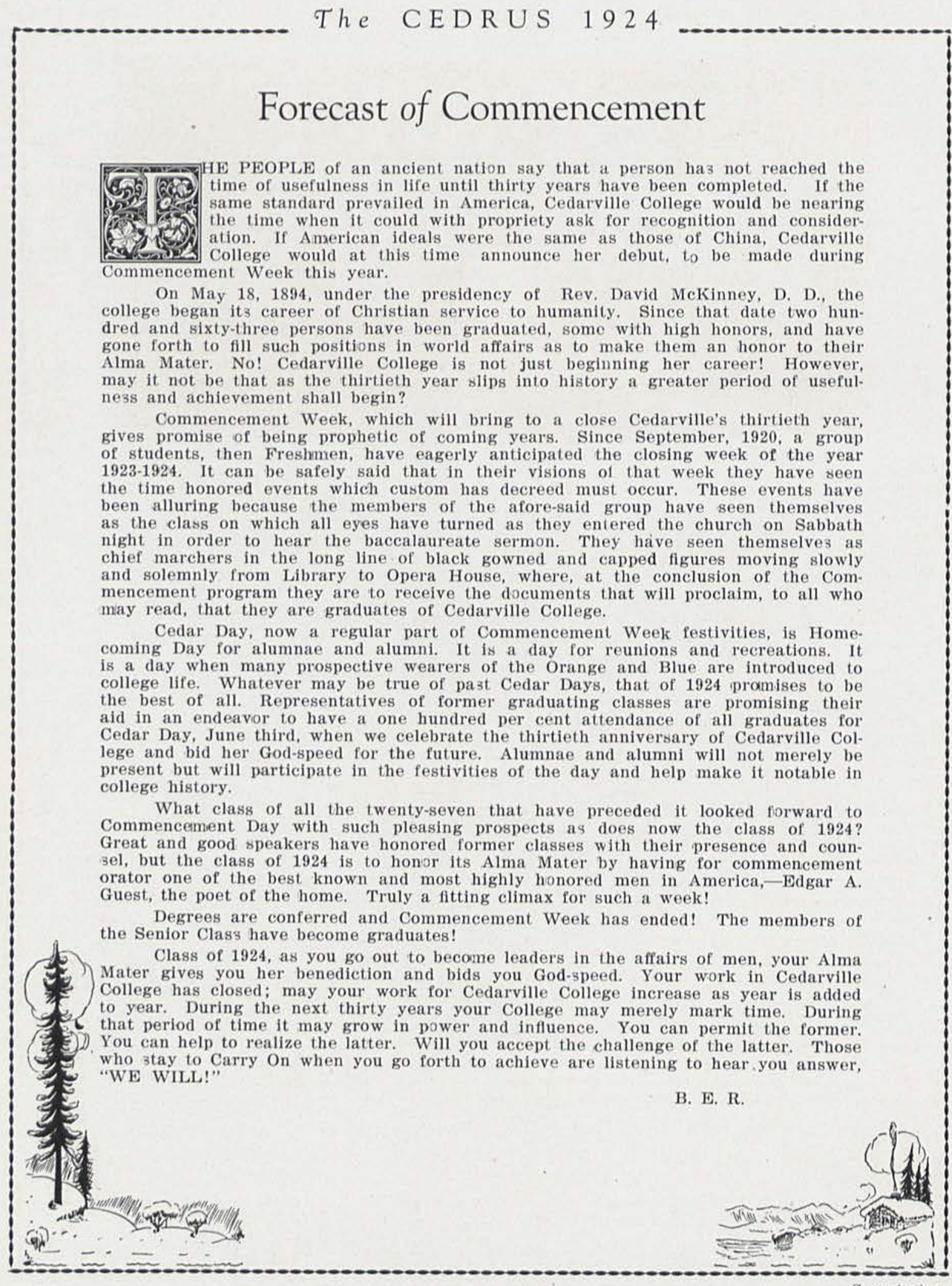

Seventy-two 
The CEDRUS 1924

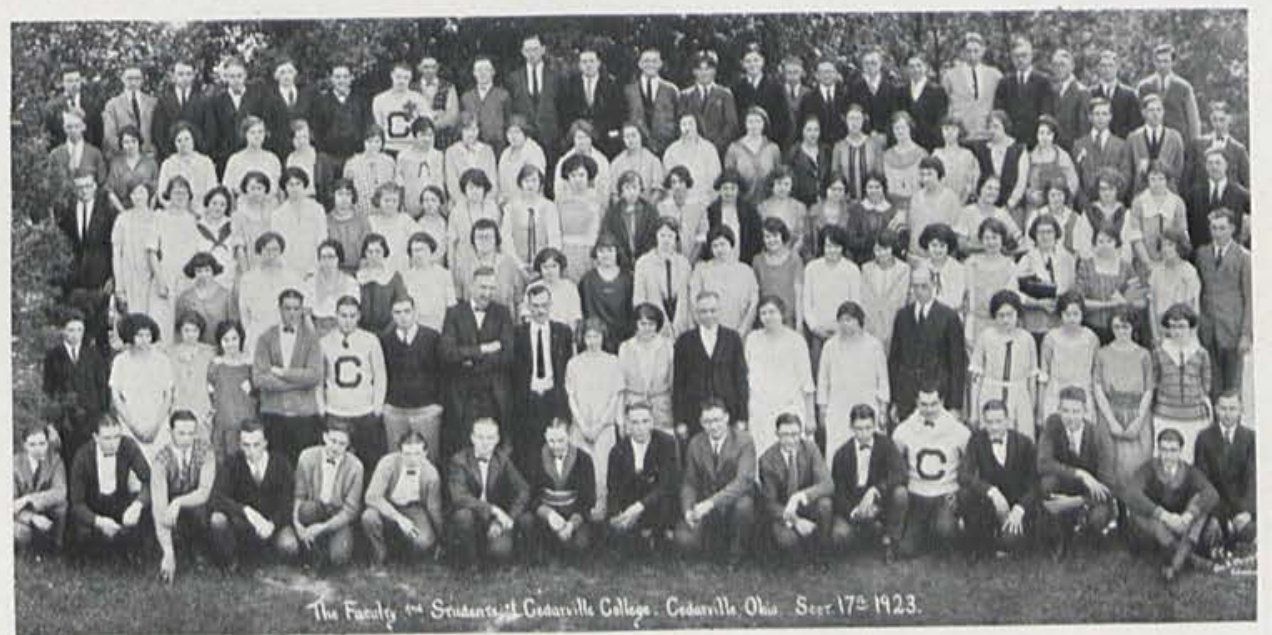

\section{Cedrus Calendar}

April 27-Showers for Miss Brand.

May 14-French Club has covered dish supper.

May 23-College gluttons enjoy Senior picnic at Bryan Farm.

May 25-Junior-Senior Banquet at Community Hall.

May 31-Teachers' delight week. The weather was Passing Fair.

June 3-C. C. Baccalaureate services at R. P. Church.

June 4-Senior Play, "Come Out of the Kitchen," at the Opera House.

June 5-Early birds' breakfast at cliffs. Faculty reception on College Campus.

June 6-Cedar Day. We go into the 'movies.'

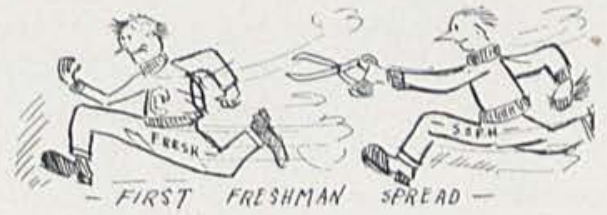

June 8-Senior revelry. College commencement. Homer Henderson and Wilbur D. Nesbit address us.

June 9-Important date; "Pop" Warner jumps into double harness.

Sept. 11-Coach and some students arrive. Football practice starts.

Sept. 12 - C. C. Watermelon feed. College opens its 30 th year.

Sept. 17-Soph. weiner roast at Indian Mound. Drew quite a crowd, Student body picture taken.

Sept. 22-Cedarville, 9-Antioch, 25. Off, to a bad start.

Sept. 25-Hon. S. D. Fess speaks in High School auditorium. Freshman truck ride to Lonesomehurst. No eats discernable. Baker goes down for the count and Yank does a 'Tom Mix.'

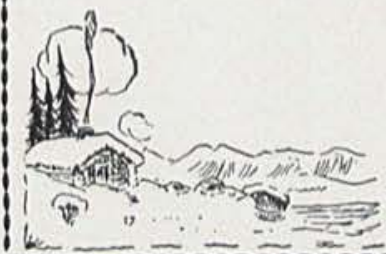

Seventy-three 
Sept $26-$ Rev. Gray of Jamestown in chapel.

Sept. 29-We won by golly-Cedarville, 7; Findlay, 0.

Oct. 4-Methodist social for college students.

Oct. 5-Pigskinners leave for Hoosier battle.

Oct. 6- Hoosiers win by small margin. Just wait. Earlham comes here in '24.

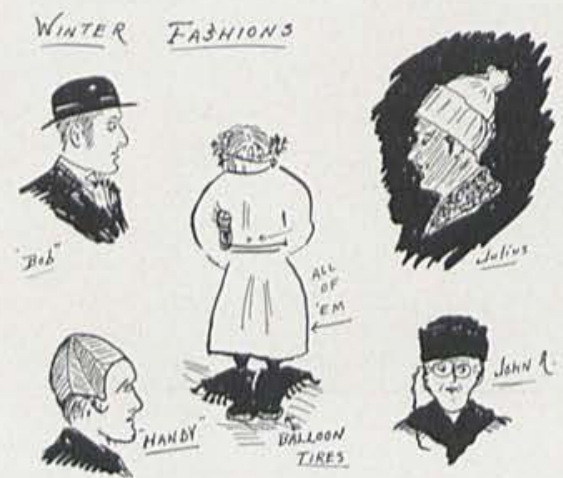

Oct. 9 - C. C. weiner roast on campus. Pep committee organized.

Oct. 11-Rev. Moyer of Beaver in chapel. Junior spread on Peelee Island.

Oct. 16-Freshmen challenge Sophs, to football game.

Oct. 19 -Fresh.-Soph. struggle 0 to 0 . You didn't miss anything. Freshmen caps all sold. Green buttons remain in place.

Oct. 26-Sidewalks, busses, and autos decorated for Rio Grande fight.

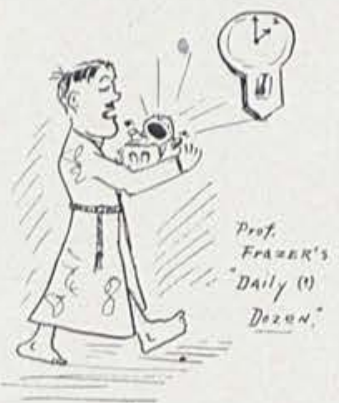

Oct. 27-Rio Grande hogties us. Some trophies as a result.

Oct. 29-Hallowe'en party in Gym. Several lose seven year's growth.

Nov, 6-Election day for politicians. Collection day for Y. W. C. A. Marion Stormont

gets one vote for Assessor. (?)

Nov, 8-Orange and Blue paper everywhere. Bon Amied all the windows.
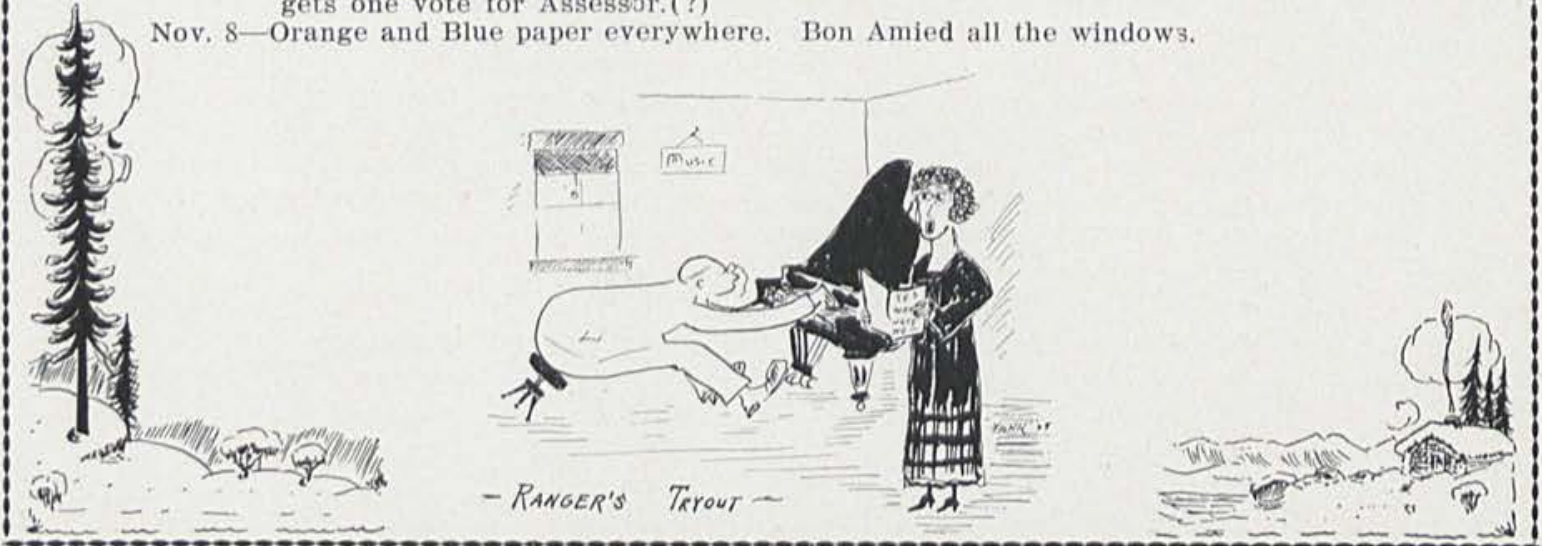

Seventy-fou: 


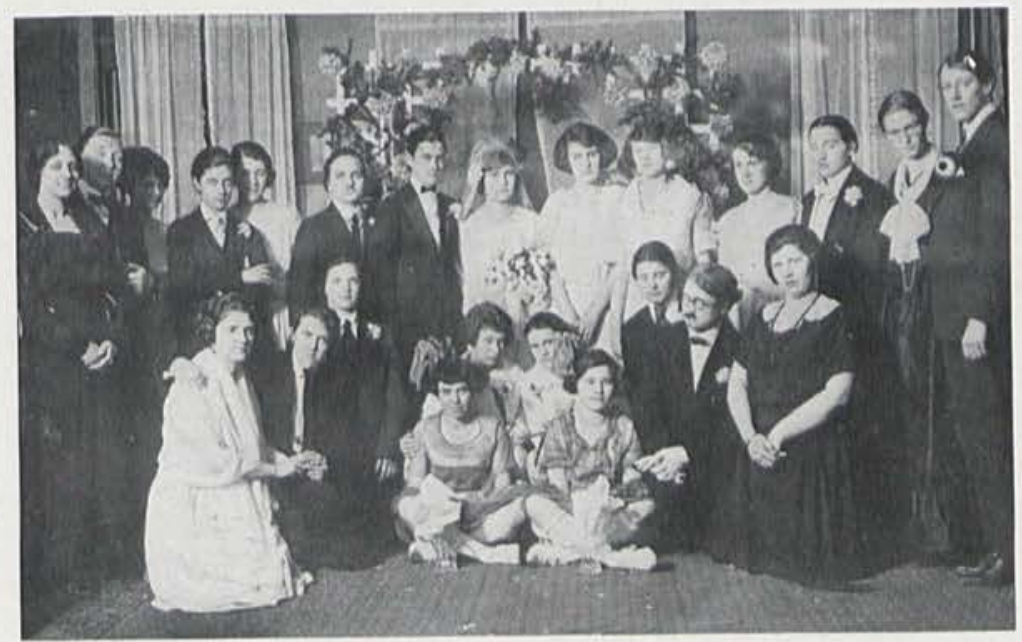

\section{Mock Wedding}

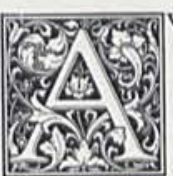

VERY INTERESTING EVENT of last year was the mock wedding. This memorable happening was held at the home of Lucile Johnson. A; the time grew near, all was astir with excitement, but not one word escaped to the boys. The night set had arrived, and all, decked out in their best apparel wended their way down Xenia Ave., with the exception of two girls, who later in the evening made a thrilling and startling entrance through a window. They had received gentle treatment, in the way of having their hands and feet bound, halters on their heads, and a nice promenade on the Columbus pike.

The house was beautifully decorated with chrysanthemums. The guests were ushered into the large reception hall and breathlessly awaited the arrival of the bride and groom.

Amid this expectant silence a sudden stir was heard on the stair, and a twisting of heads followed as the old familiar strain, "Here Comes the Bride," pealed forth. The bridal procession was coming, lead by the flower girls, followed by the bride, Marjorie Wright, and bridesmaids, up to the altar, where awaited the groom, Hazel Williams, and Rev. Somers. The pair were married under an arch of ferns, lilies and chrysanthemums. The bride was very lovely in her white crepe de chine dress, carrying her bridal bouquet. This solemn performance was at this point interrupted by the arrival of uninvited guesis who assisted in taking the marriage vows; and giving advice as to how it should be managed. This untimely interruption was welcomed and expected as a part of the program.

This was followed by a four course dinner. The bride's table was beautifully decorated in yellow and white. The salad had disappeared, the ice cream had seemingly melted, but these slight clouds of irritatior and disappointment were soon forgotten in the pleasure of the evening. The bridal cake was cut and each guest received a piece which doubtless brought many pleasant dreams. The mar(1)
riage feast broke up at a late hour and after many congratulations and good wishes
had been showered upon the newly married pair, the guests all departed.
R. D.

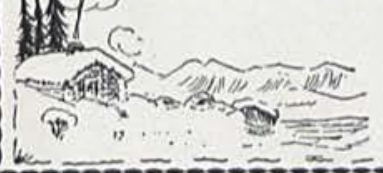

R. D.

Seventy-flve 


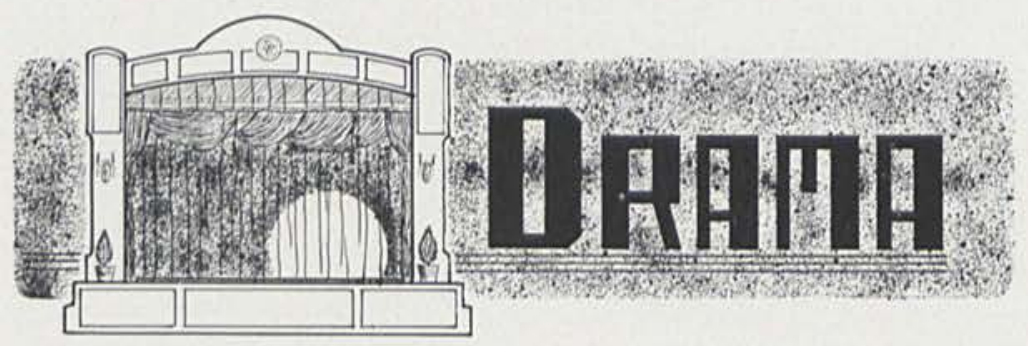

\section{And Billy Disappeared}

After spending a week in reading plays, the play, "And Billy Disappeared," was selected by the Junior Class. The whole class was included in the cast. After working hard and steady, under the most excellent directorship of Miss Florence Somers, the play was ready to be given. It proved to be a great success and the Juniors could not help but compliment themselves because they had prepared it in such a short time.

The cast was All Star. Mr. Donald Wickerham played the part of Billy and Miss Hazel Williams, his sweetheart, while Miss Lucile Johnson and Mr. Marion Stormont furnished much amusement for the audience. Miss Lucinda Caskey and Mr. Dell Wickerham played a thrilling love scene. Miss Thelma Deacon made a delightful old lady. The costume and the acting of $\mathrm{Mr}$. Gavin Reiley made him a hermit to be avoided, and Miss Christine Kyle a clever, and amusing colored maid.

\section{Come Out of the Kitchen}

This play was presented by the Senior Class as their last services to the college. It was an All Star cast with Miss Marjorie McClellan and Mr. Earl Collins as leads. Other members of the cast played their parts well. The staging was excellent, the complete kitchen was shown and a delicious meal was served. This was the first event of Commencement Week and started it off with much pep and enthusiasm. The play was very successful and was enjoyed by many alumni who had returned to Cedarville for Commencement Week.
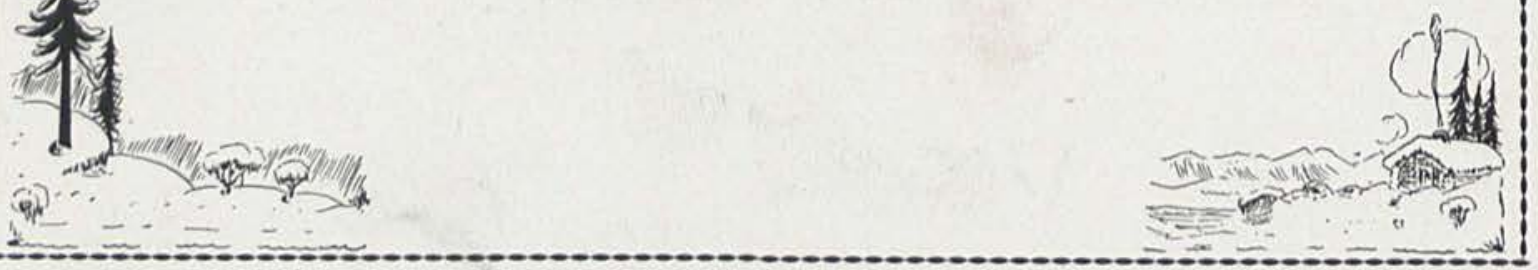

Seventy-six 


\title{
The CEDRUS 1924
}

\section{The Wrong Mr. Wright \\ presented by}

\author{
The Cedrus Staff
}

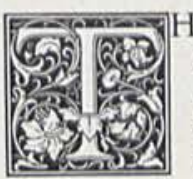

HE CEDRUS STAFF, finding that there was likely to be a small deficit unless more money could be secured, decided to stage a play. The play selected by the staff, after some discussion, was "The Wrong Mr. Wright." This was a typical farce and of a type that has been found to be popular in Cedarville. The cast was made up of members of all the classes and was an exceptionally talented group.

Mr. Turnbull played the part of the gallant young captain, with Miss Oglesbee as the heroine. They made a handsome looking couple, and were excellent in their roles. Mr. Ray played the part of the eccentric Mr. Wright and was madly smitten by the charms of the young lady detective, played by Miss Dorothy Wilson. Miss Betty Gifford and Mr. Stormont played opposite; she as the young maid who was ambitious to marry a real Lord, which was played by $\mathrm{Mr}$. Stormont. Miss Gifford with her grammatical errors and Mr. Stormont with his "I am a Killer," furnished much amusement for the crowd. Miss Gifford's solo dance brought a round of applause. Miss McPherson was quite striking as "The Unappropriated Angel," and much of the success of the play was due to her clever acting. Mr. Cooper and $\mathrm{Mr}$. Barlow gave splendid interpretations in their parts. $\mathrm{Mr}$. Wills and $\mathrm{Mr}$. Huston were live wires in their roles.

The success of the play was due largely to the splendid and tireless labor of Mr. Markle who directed the performance. Mr. Markle's ability as a player is well known and now he has become known for his ability as a director. The Staff wishes to thank all who had a part and also the village for supporting the play so royally.

\section{The Importance of Being Earnest}

It is always the custom in Cedarville College to have one play a year in which the members of the student body have a chance to take part. This play is given before the Christmas Holidays and is always looked forward to by the students and people of Cedarville. This year the play was given the last of November. The cast was made up entirely of Freshmen and Sophomores with the exception of one. Much new talent was developed, which we have used throughout the year. It was a much heavier type of play than is usually given by the students of the college, and much credit is due both to the director, Miss Somers, and to those who took the roles. The play was enlivened by some of the young gallants of the college who attired themselves in flannels, regardless of the snow and season. They had provided themselves with beautiful bouquets of paper flowers, which they gracefully threw to their lady loves as the latter came out on the stage. This was appreciated by all and a most enjoyable evening was had.

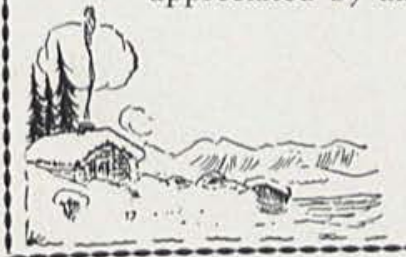

Seventy-seven 


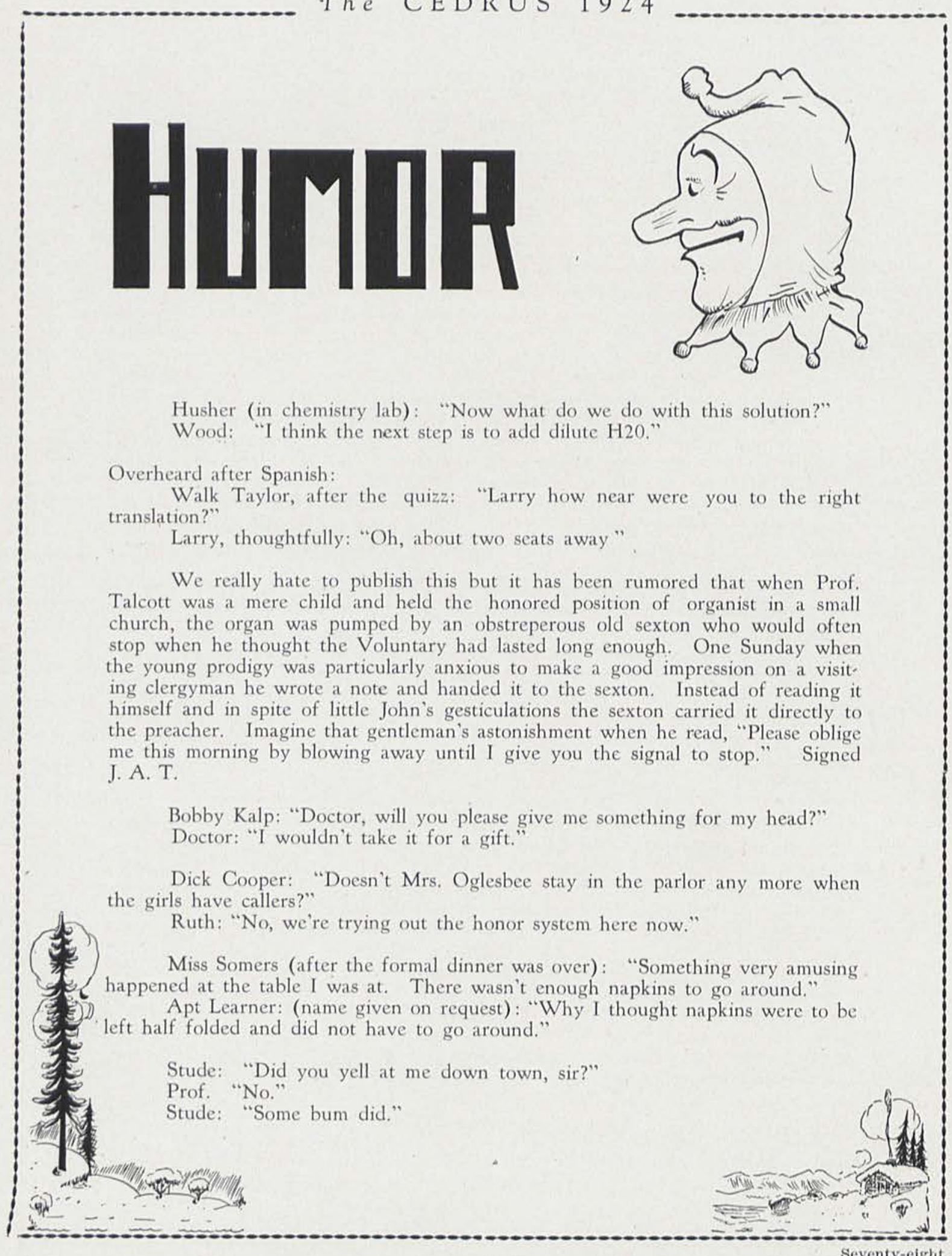


Mary Townsley: "Miss Tinker says my translations would be better if they weren't so literal - if I would only read between the lines more,"

Dorothy Wilson: "Well why don't you?"

Mary: "I can't; its half erased."

Paul Orr: "Look at that girl. She is as pretty as she can be." campus."

Tiffany: "That's nothing. There are a lot of girls in that fix on this

Prof. Jurkat: "Listen closely to this lecture on History, you don't know any" thing about this subject, you are all ignorant or else you wouldn't be here." joke?"

Staid Senior: "Why on earth don't you laugh when Prof. Jurkat tells a this week."

Second Staid Senior: "I don't have to. I'm leaving college at the end of

Prof. Frazer: "Husher, what does A stand for?"

Husher: "Just a minute, I've got it on the end of my tongue."

Prof. Frazer: "Well spit it out. It's arsenic."

Mrs. Oglesbee: "How do you know that he was following you?"

Ann: "Because he kept looking around to see if I was coming."

Lois: "Walk, will you please run up the blind, we must not be so prominent."

Walk: "I am quite an athlete but I can't do that."

When Ann Ord made her first appearance at the barber shop.

"Please Mister, just cut off ten cents worth."

Don Wickerham in Plane Geometry: "Can you prove the proposition, that the square of the hypotenese of a $\mathrm{rt}$. angled triangle is equal to the sum of the squares of the other two sides?"

Markle: "I don't have to prove it, I admit it,"

Prof. Robison: "There are many different classes of people, the leisure class for instance."

Howard Arthur: "Thats me."

Prof. Robison: "I thoroughly agree with you,"

Miss Kochler: "Mr. McCoy you must think that this class is a barn."

Mc.: "Why?"

Miss Koehler: "Just one stall after another,"

Dick Cooper: "Dearest, I must marry you."

Ruth: "Have you seen father?"

Dick: "Often, honey, but I love you just the same."

Doctor Finney to Betty Gifford: "Something scems to be the matter with Doctor Finney to Betty Gifford: "Something scen
your heart. To give it a name it is Angina Pectoris."

Betty: "No, that isn't his name at all. You'll have to guess again." 
The CEDRUS 1924

A VERY LARGE CONTRIBUTING FACTOR TO THE SUCCESS OF THIS BOOK IS THE ADVERTISING.

ON BEHALF OF THE CEDRUS STAFF OF THIS YEAR I WISH TO THANK ALL WHO HAVE CO-OPERAT. ED WITH US IN THE MAKING OF THIS BOOK. WE TRUST THAT THE STUDENTS WILL SHOW THEIR APPRECIATION BY PATRONIZING THEM.

MARION STORMONT, Editor-in-Cliief 


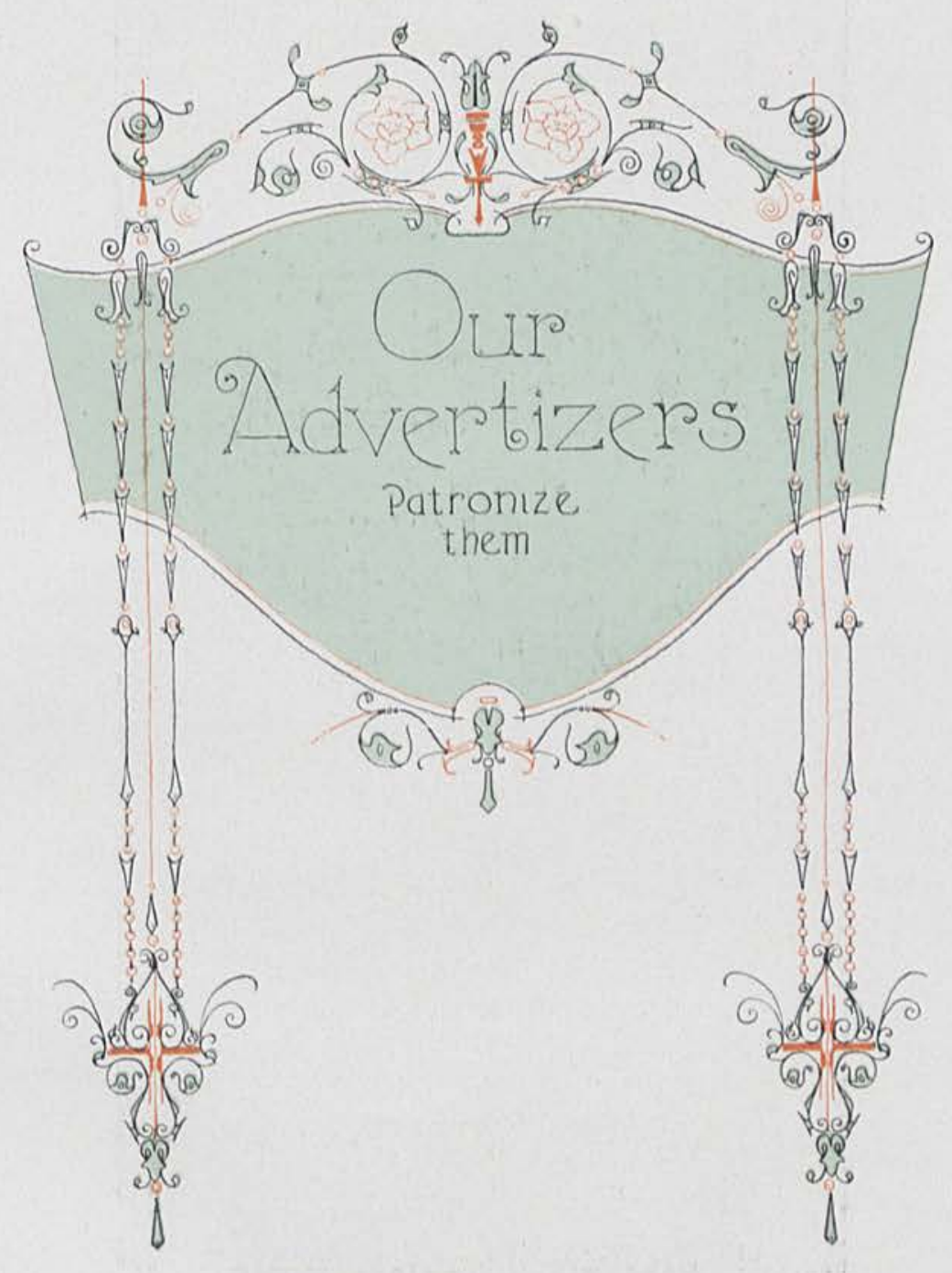




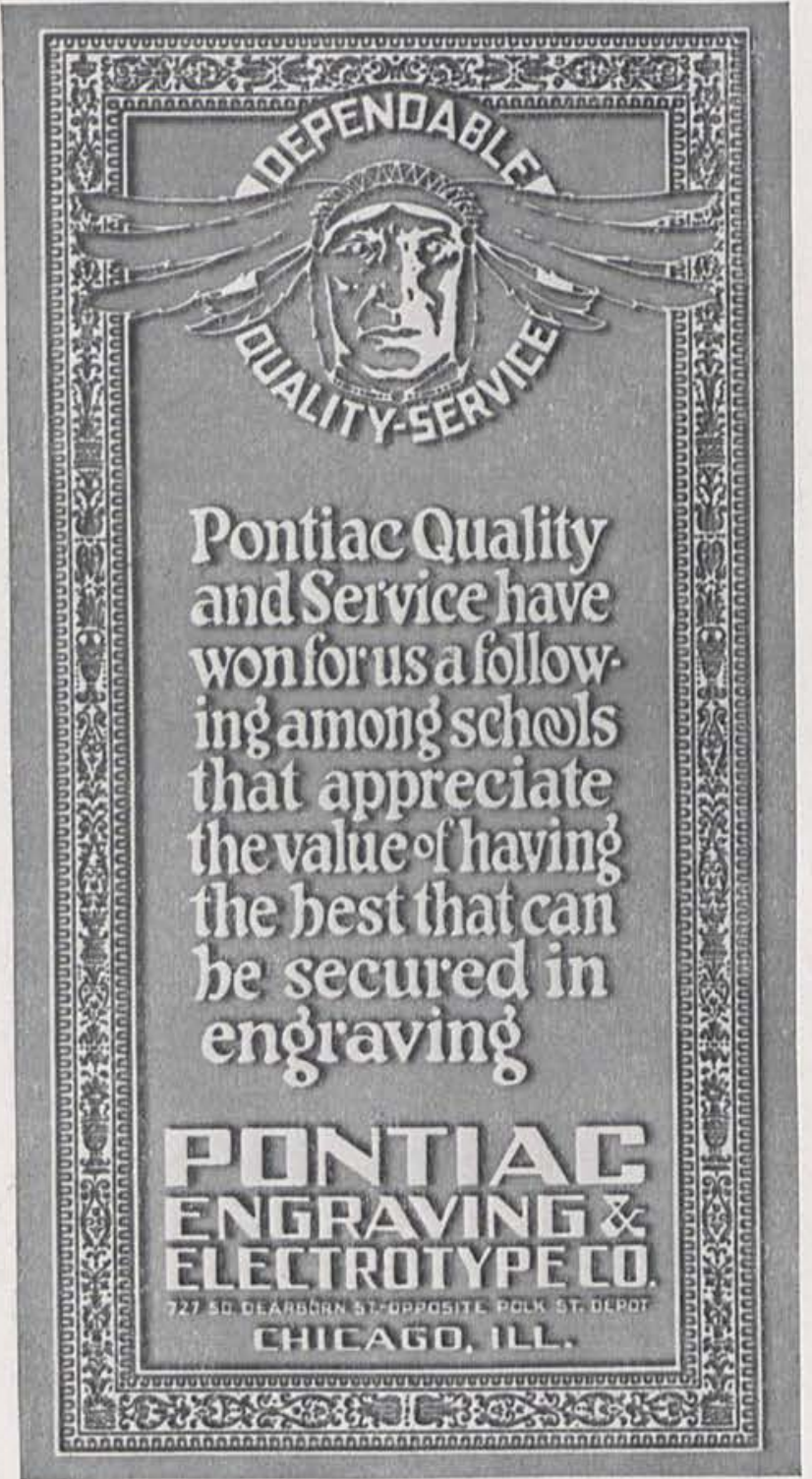




\section{Cedarville College}

\section{Is Forging to the Front}

Get A College Training

The times demand it.

The results justify it.

Come to Cedarville College

The location is healthful and beautiful.

The opportunities are fine and inspiring.

The courses are complete and modern.

The influences are safe and helpful.

The expenses are lower than at many other places.

The students are possessed of high ideals and practice them.

The faculty is experienced and thoroughly trained.

Foot Ball, Basket Ball, Base Ball and Tennis

Physical-Education and Gymnastics

The College is recognized by the Department of Public Education of the State of Ohio, and by the leading universities.

The Greene County Normal for the training of Elementary Teachers is affiliated with Cedarville College and is recognized by the Department of Public Education of Ohio.

In Cedarville College you can get preparation for any pursuit in life.

A large Freshman class is to enroll in September. The prospects for a record-breaking attendance are splendid. Largest attendance in history of the College last year.

Thirty-first Year Opens September 10, 1924

For catalog and further particulars, address

W. R. McCheSNeY, Ph. D., D. D., President

Cedarville, Ohio

Eighty-one 


\section{Did you Meet--Sammy Sweet at the Quality Sweet Shoppe in Xenia}

He sure knows his "stuff" when it comes to making swell Sodas and Sundaes

We Have It - Will Get It - Or It Never Was

Interuban Restaurant

"At The Station"

When you visit Xenia there

is only one place to eat

Where you get real food and service too.

Open day and night

DOUTCHOS BROS., Props.

Dorothy Wilson (translating in

French): "The thief fled with all his feet."

Bill Snell: "Why do blushes ereep over girls' faces?"

Lelia: "Because if they ran they would kick up too much dust."

Elmer Jurkat (tall boy in the movie house): "Can you see anything Paul."

Paul Orr: "Not a thing."

Elmer: "Well then I know what to

do. Watch me, and laugh when I do."

\section{S. BARNES \& CO.}

Wall Paper \& Paints Decorators

Picture Framing Stationery

Greene St. Xenia, Ohio
Merchandise that is seasonable

Prices that are reasonable Clothing, Hats and Shoes For The Whole Family

HOME CLOTHING CO. G. H. HARTMAN, Prop. Trade at Home

Scheaffer Student Special FOUNTAIN PENS

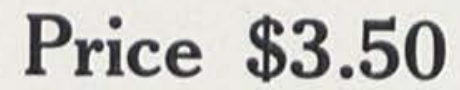

Tiffany Jewelry Store XENIA, OHIO

\section{Wood's}

\section{Barber Shop}

Try Wood's Special Hair Tonic

18 West Main Street XENIA, OHIO 


\section{"What's What"}

\section{In Matters of Dress}

Even a casual inspection of the new creations for Spring leads one to the conclusion that makers of men's clothing gave their resigners free rein. Apparently they set out with the determination to please every man who expresses an interest in new clothes, regardless of his age, vocation, proportion and taste.

Styles in men's clothes do not change over night, because men are not as susceptible to the whims of fashion as is the fair sex.

But a change in style in men's clothes does occur about every so often, and this Spring marks the transaction from the typical American to the Americanized British idea in suits and topcoats.

It is because of this tendency toward a different type of clothing that stocks of men's clothing afford so wide a latitude in selection.

So, the man in search of new clothes can find exactly what he wants with surprising little effort.

He may choose the cleancut, form-tracing style that has long been associated with the vigorous, athletic American.

Or, he may go in for the British idea which achieves smartness by straight lines and a free-and-easy swing and swank. A style that looks well on almost every figureslender, stout, or in between.

Topcoats, and of course, every well dressed man must have one nowadays, are cut over comfortable lines, too, Rather full-skirted, draping easily from the shoulders. Some styles have a belt at the back, but the favored style seems to be the straight back effect.

While men have come to accept the conventional stripe in its many variations; or the solid shades in blue, gray and brown, they are due for a surprise this season.

Designers and weavers evidently decided to give the men folk a treat this Spring. We have never seen such a wealth of rich color as the new fabric display. Powdr blue, sapphire gray, crushed blue, mauve, ocean green, and many others. And the interesting feature is that none of them oversteps the bounds of good taste.

So, men can approach the task of selecting new clothes this Spring with the comfortable assurance that selection has been simplified through the efforts of designers, weavers and tailors.

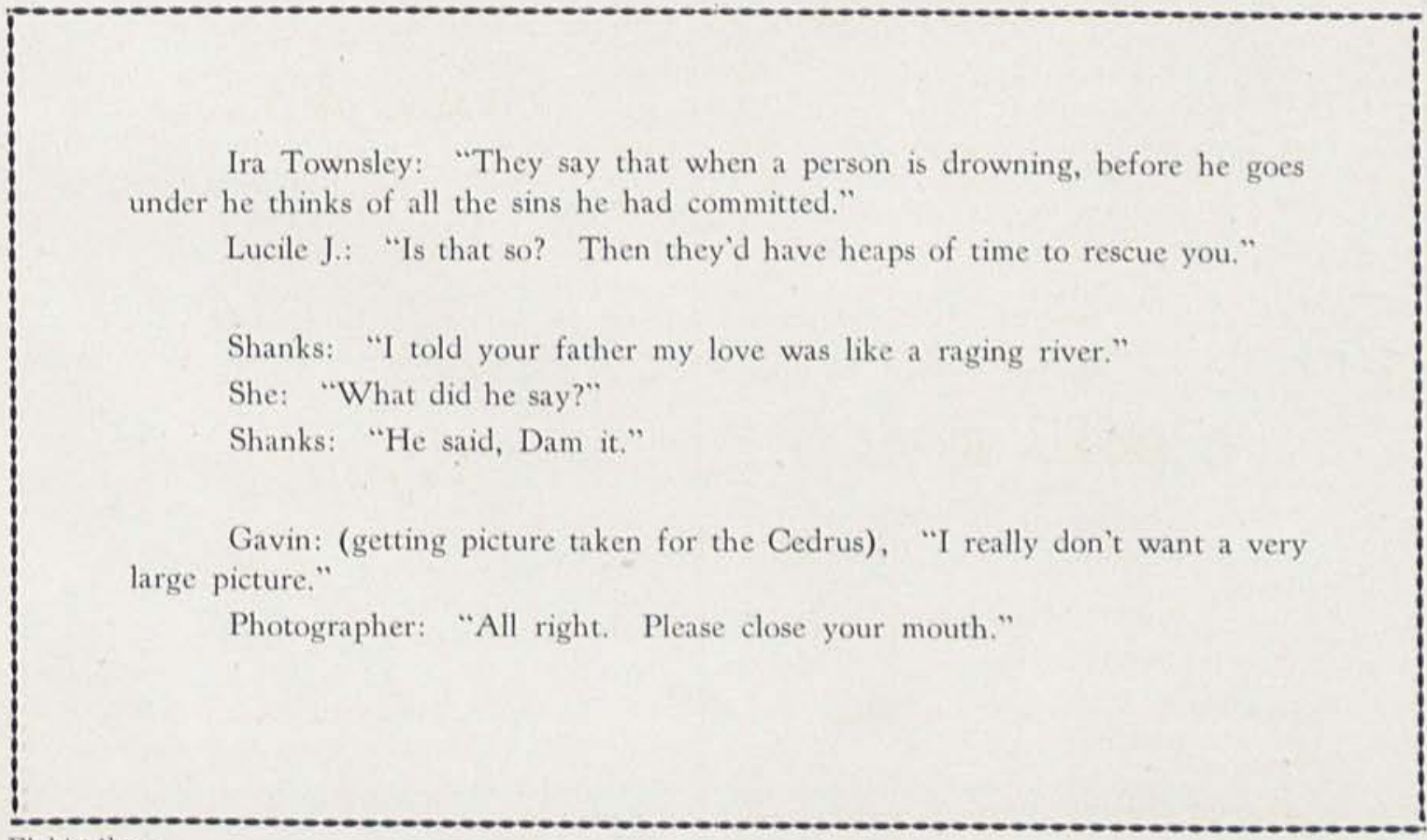

Eighty-three 

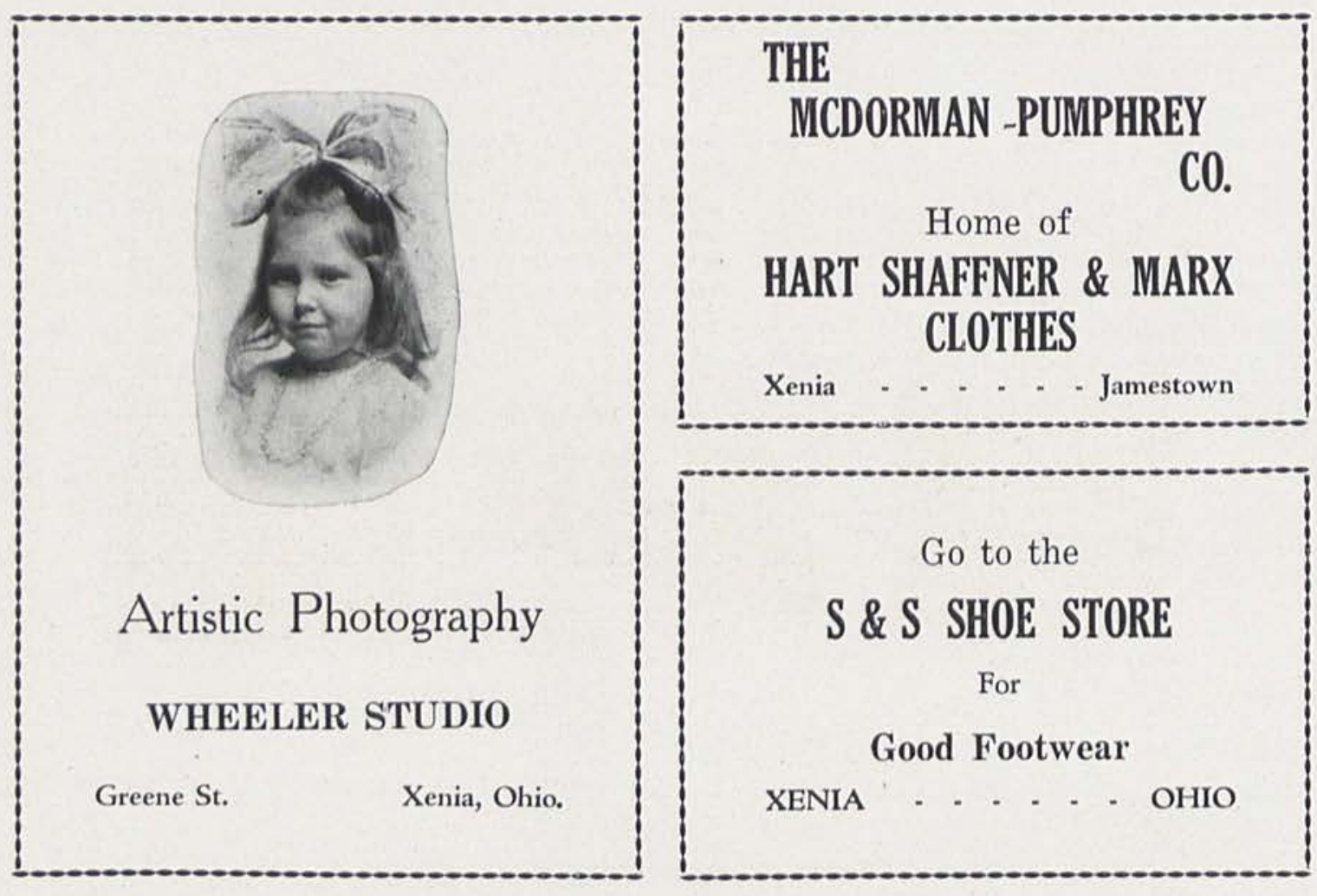

They met - they kissed. He wrote a poem.

"Walk, don't you think you could write a book?"

The Battle

Out in the moonlight two figures were engaged in a terrific struggle. It was a contest to try the fibre of which man is made. Long and silent waged the gigantic combat. The uncertain light revealed little of the com. batants; nothing could be heard except the labored breathing of the smaller figure. Suddenly he threw his whole being into the battle with a show of awful energy. The combat assumed gigantic proportions. Then the larger emitted a terrible roar, and the contest ceased. The flivver had started at last.

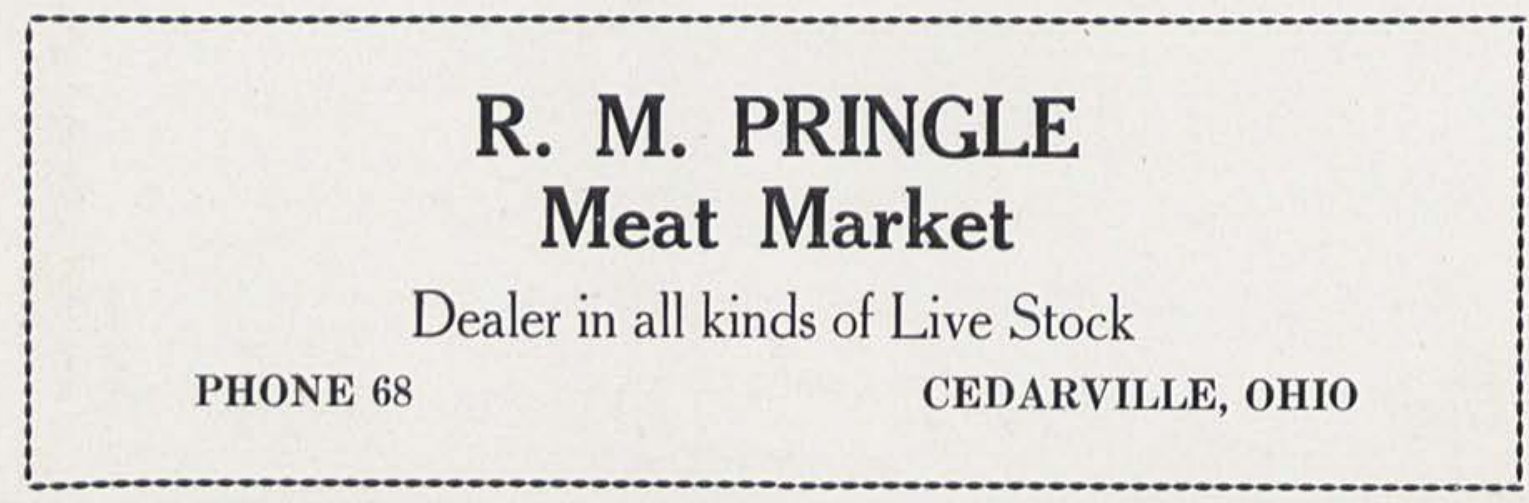




\section{The CEDRUS 1924}

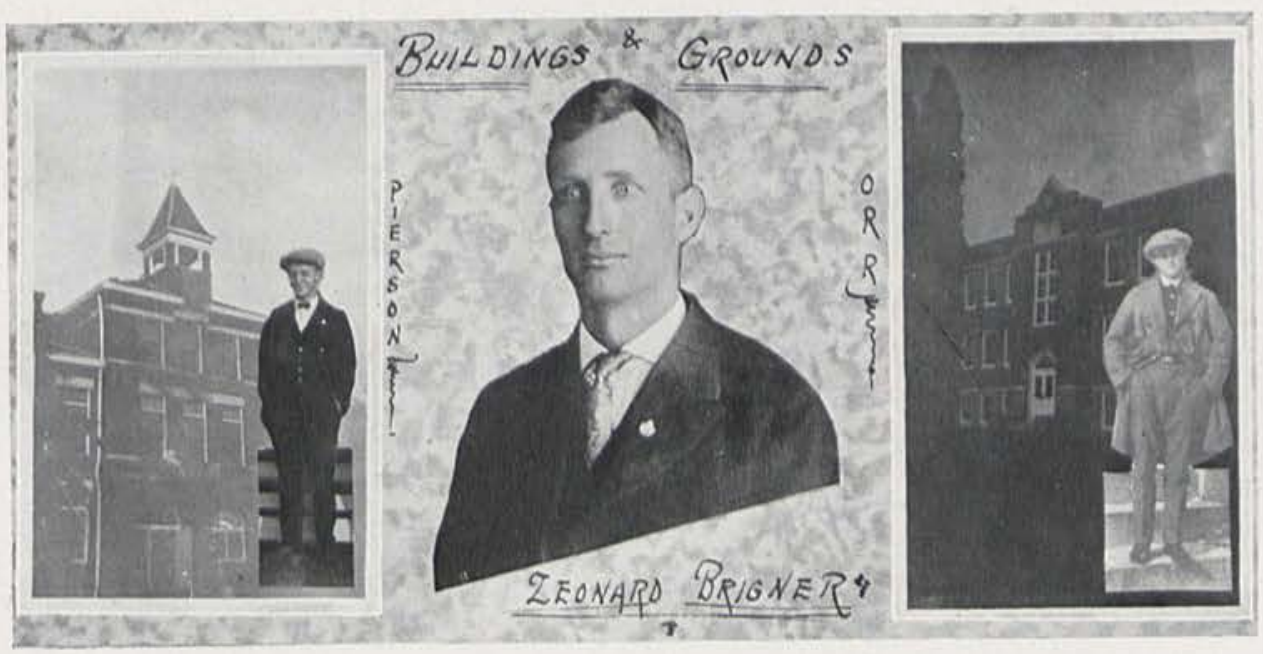

Nov. 9-Orange and Blue meets Orange and Blue. Orange and Blue wins.

Nov. 14-Dr. J. W. Colman in chapel.

Nov. 27-Wheeler taking Cedrus pictures. Camera suffers a relapse.

Nov. 28-Thanks for our Thanksgiving vacation.

Dec. 5-B. B. season tickets $\$ 2.50$.

Dec. 6-Cedarville 41, Springfield B. C. 11. There aint no flies on us.

Dec. 12 -"The Importance of Being Earnest." Important crowd with ice cream pants entertain themselves in the front rows.

Dec. 15-Girls play Spr. Y. W. Boys play Bliss Bus, "U." Aw forget it.

Dec. 17 - Girls beat Wilmington 16-15. We forget whether the boys won or lost. diamond in their stocking.

Dec. 23-Rumors denied.

Dec. 26-The morning after-that sinking sensation-and the dark brown taste. Several from C. C. take in the "Gingham Girl."

Dec. $28-$ C. C. upsets the dope and sets up a $25-23$ score against Defiance.

Jan 1-Again it is upon us. The annum with the extra day that causes so much anxiety to the stronger sex. New Year resolutions made.

Jan, 3-'Handy' measures his gas with a match. The gas proves to be a match for him.

Jan. 14-Revival of Philadelphian Literary Society.

Jan. 21-25-The Passing Show. A few show passing cards.

Jan. 29-Registration Day.

Feb. 8-Day of Prayer. Bishop Theodore Irving Reese gives address. LyceumMargaret Stahl gives Drinkwater's "Abraham Lincoln."

Feb. 14-Valentine party at Pres. McChesney's. Several surprises.

Feb. 16-"Babb means Beat." We were a little better. Score 25-16. prize fumbles.

Feb, 25-David whips Goliath again. Cedarville 19, Antioch 17.

Feb. 29-That extra day. Rev. Shields in chapel.

Mar. $7-5$ A.M. Breakfast at Martindales, It snowed, and I don't mean maybe,

Mar. 13-Class tourney. "Soph" changes to Soft.

Mar, 16-Eddie Bradfute addresses us.

Mar. 26- Spring fever.

Mar, 28-We review "Human Wreckage." No effect. Dope fiends at "Doc's" are as numerous as ever.
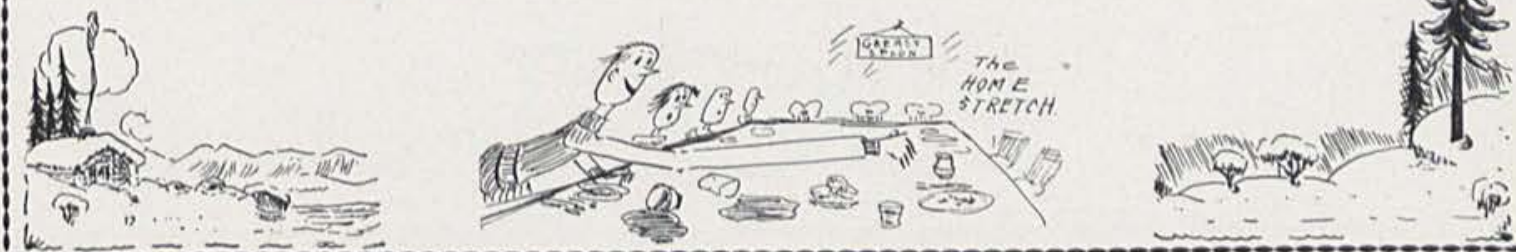

Eighty-flve 
Deposit your Savings with

\section{THE EXCHANGE BANK CEDARVILLE, OHIO}

$4 \%$ interest paid on Savings and Time Certificates of Deposit

Resources over $\$ 500,000.00$

\section{WINCHESTER SPORTING GOODS}

The most complete line of Base-ball goods in the city

What ever the sport, we have the equipment

\section{Babb Means Best}

Hardware and Allied Lines

XENIA, OHIO
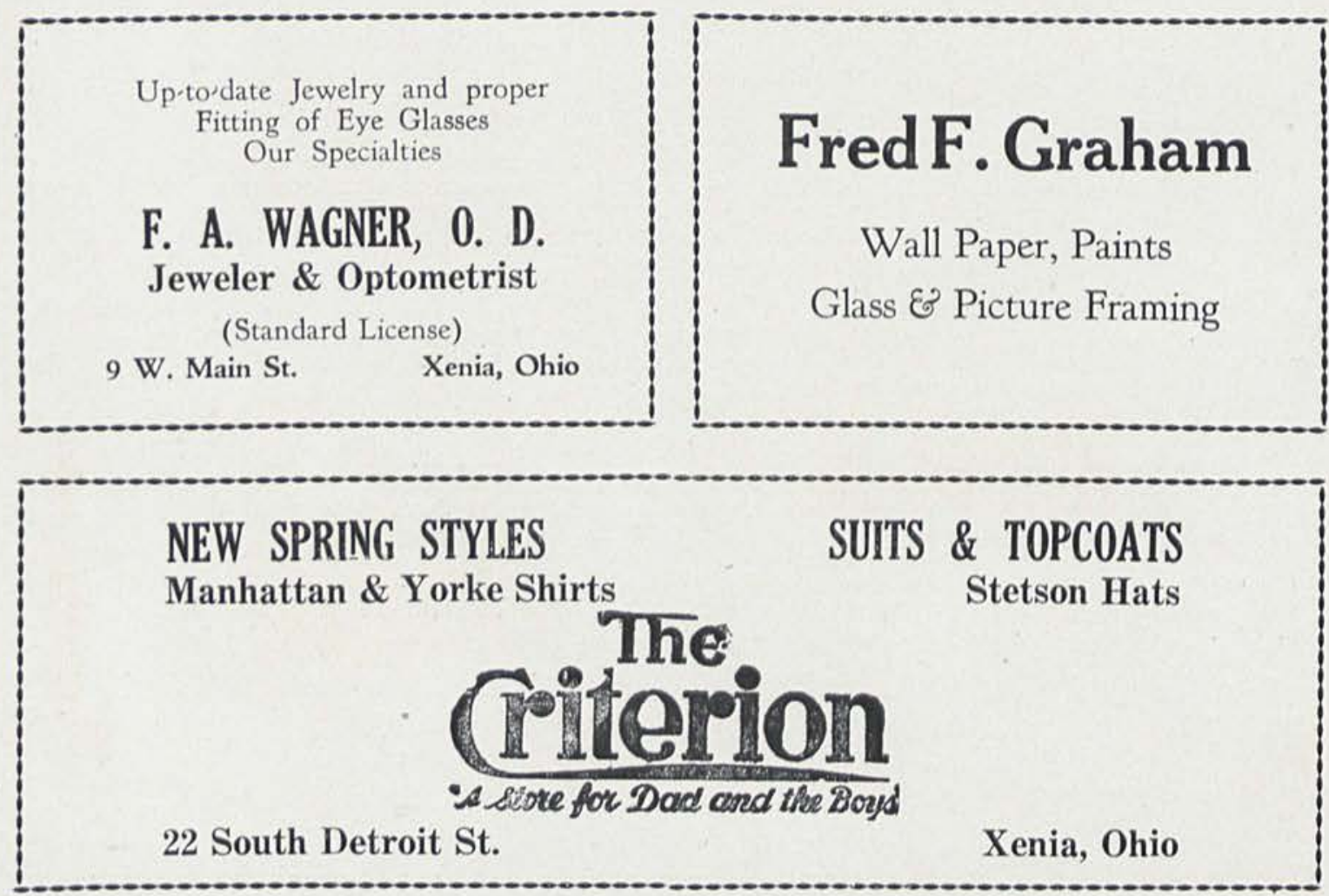


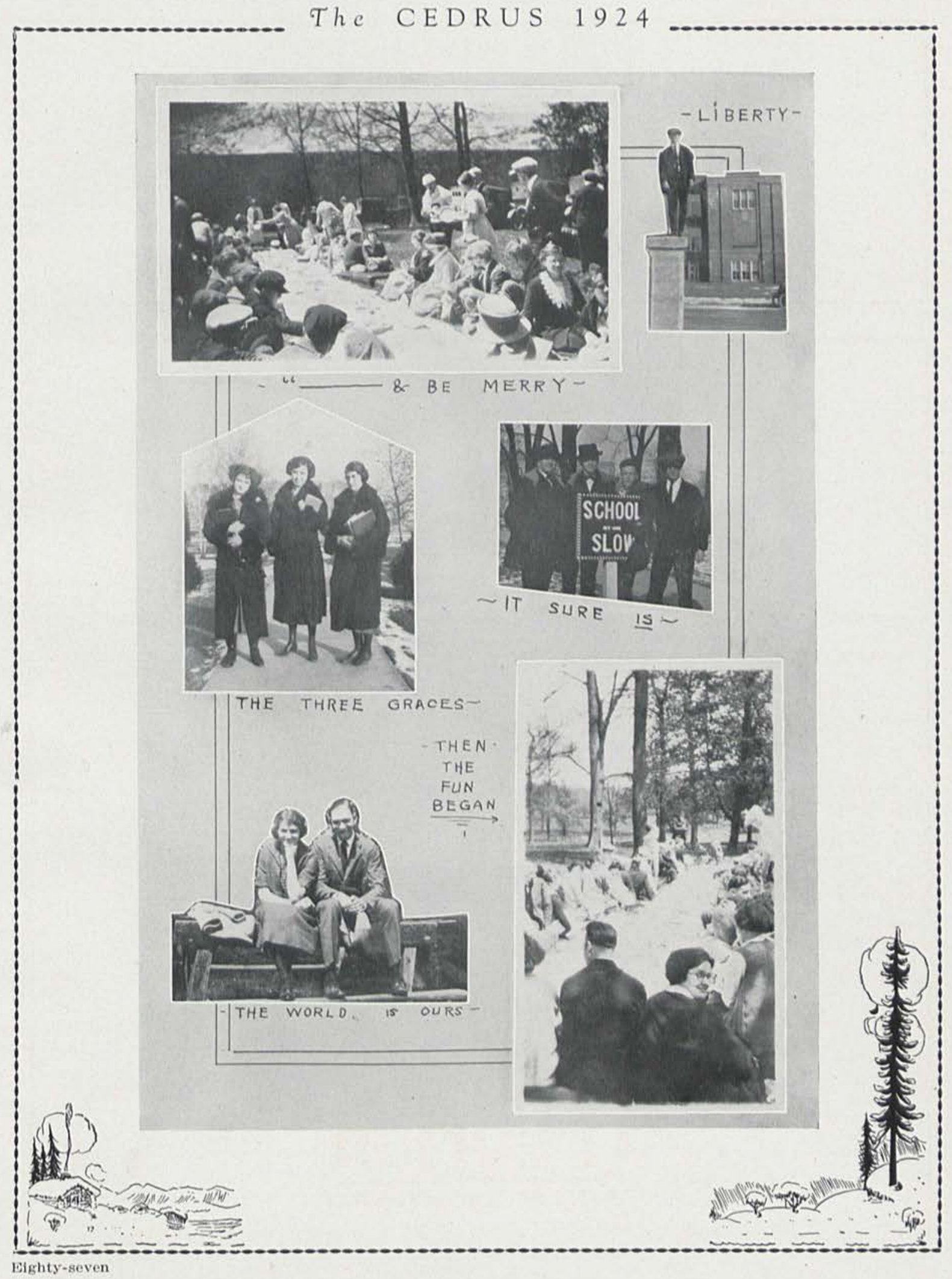




\section{KUPPENHEIMER \\ Good Clothes}

Sure - Fit_Caps

That Adjustable Kind

Van Heusen Collars

Katz \& Richards

Our meats are good and sweet

Our groceries they are fine

Thats why the Club trades here all the time.

\section{C. Nagley \\ Grocery and Meat Market \\ PHONE 40}

This Space

Suscribed For

by

THE

HUTCHISON \& GIBNEY

COMPANY

XENIA, - $\quad-\quad+\quad-\quad \mathrm{OHIO}$ 


\section{Is this your kind?}

Hickey-Freeman Clothes have the perfect fit, the soft tailoring, the correct drape, that indicates hand workmanship of the most expert kind.

\section{W. D. ALEXANDER \& CO.}

Main and Limestone Sts.

SPRINGFIELD, OHIO

\section{RITENOURS EXCHANGE}

\section{Gasoline and Kerosene High Grade Oils \\ COAL - GRAIN - FEED}

CEDARVILLE

OHIO

\section{A GREAT COUNTY IS OURS}

Its Institutions of Learning; Its Commercial Enterprises; Its Agricultural Development; Its Splendid People-All Give Cause for Pride.

A cooperative interest among its people will promote a larger growth.

The Geo. Dodds \& Sons Granite Company

Xenia, Ohio

"For Sixty Years A Greene County Enterprise."

$$
\text { -MEMORIALS - }
$$




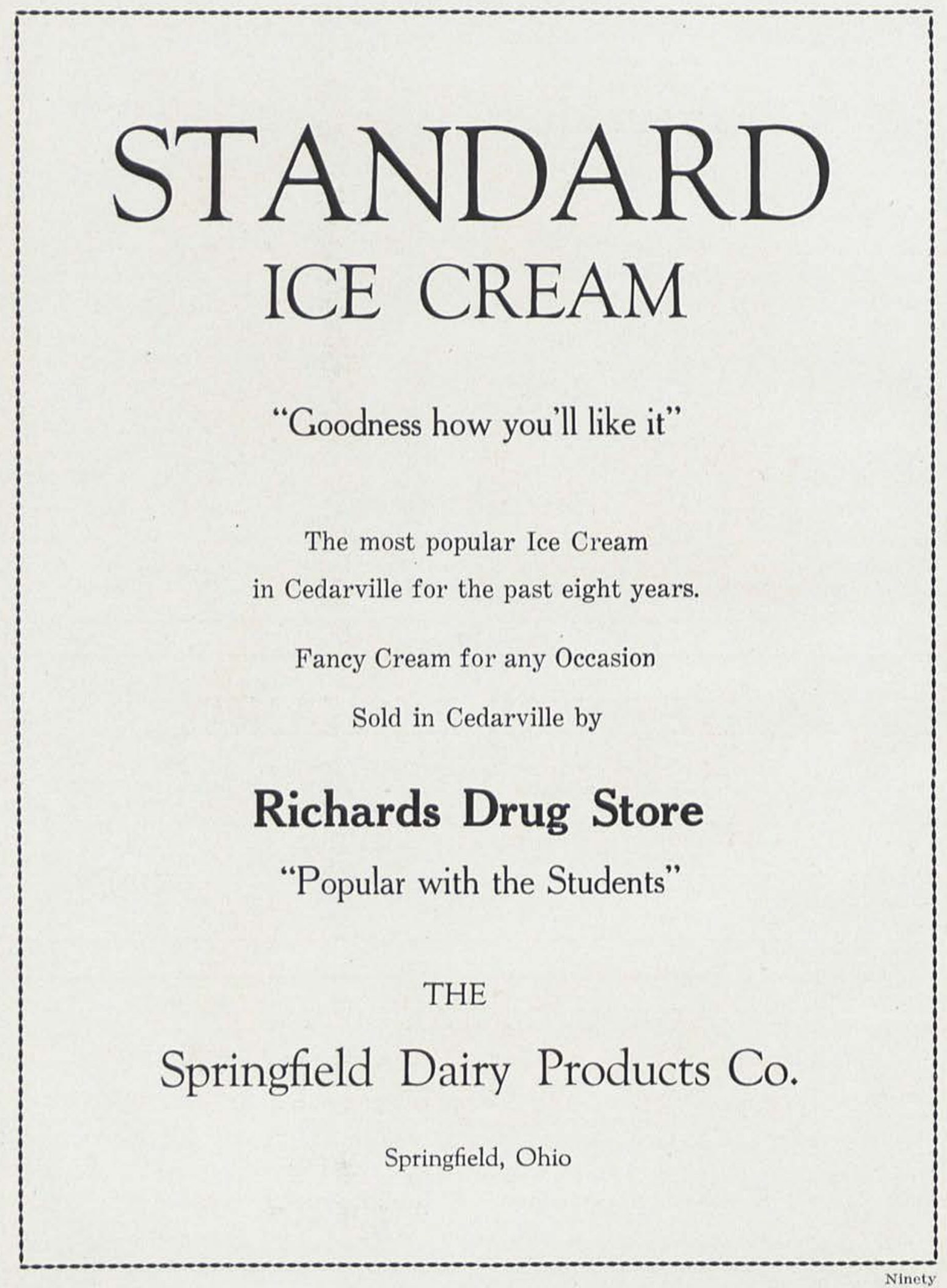


The CEDRUS 1924

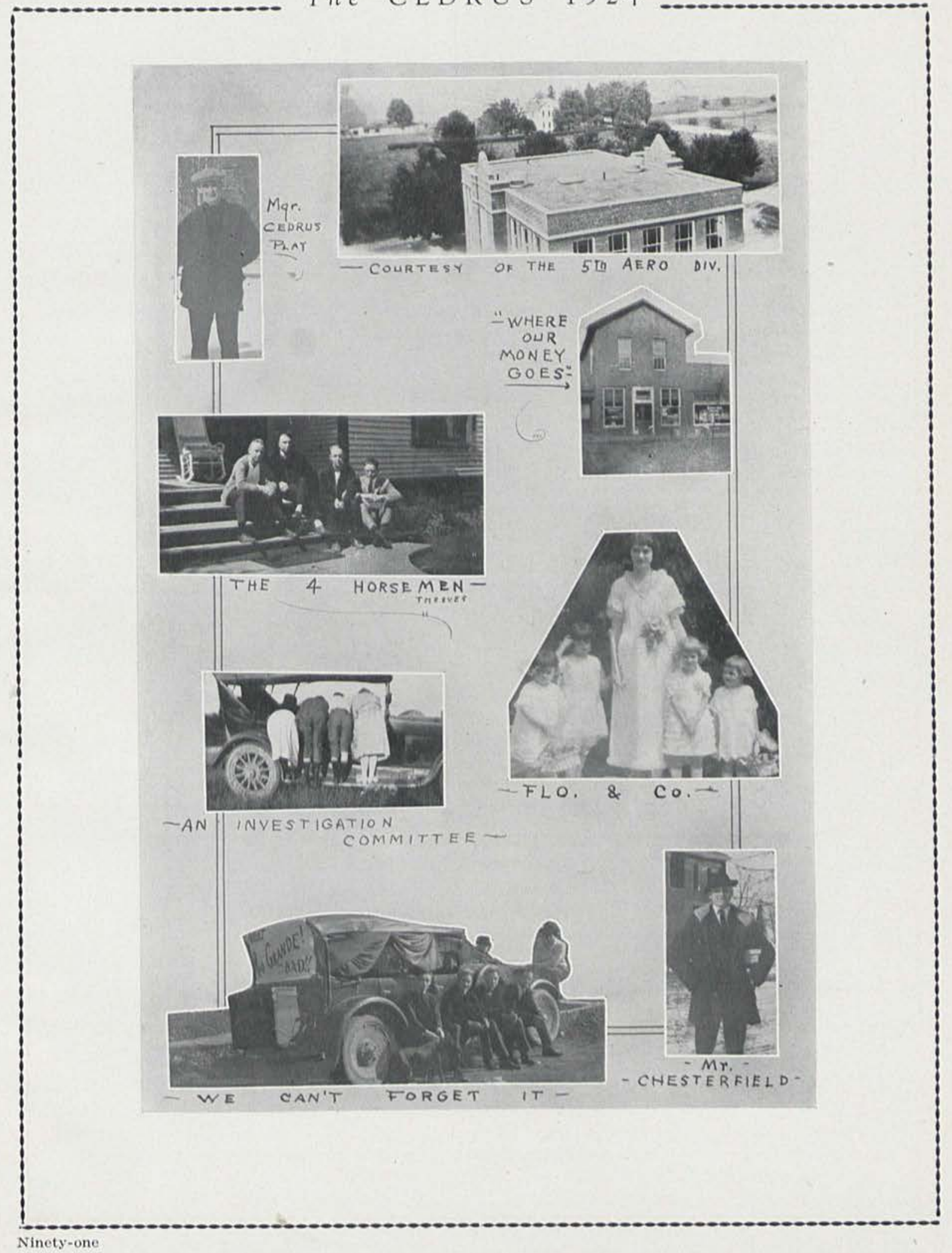



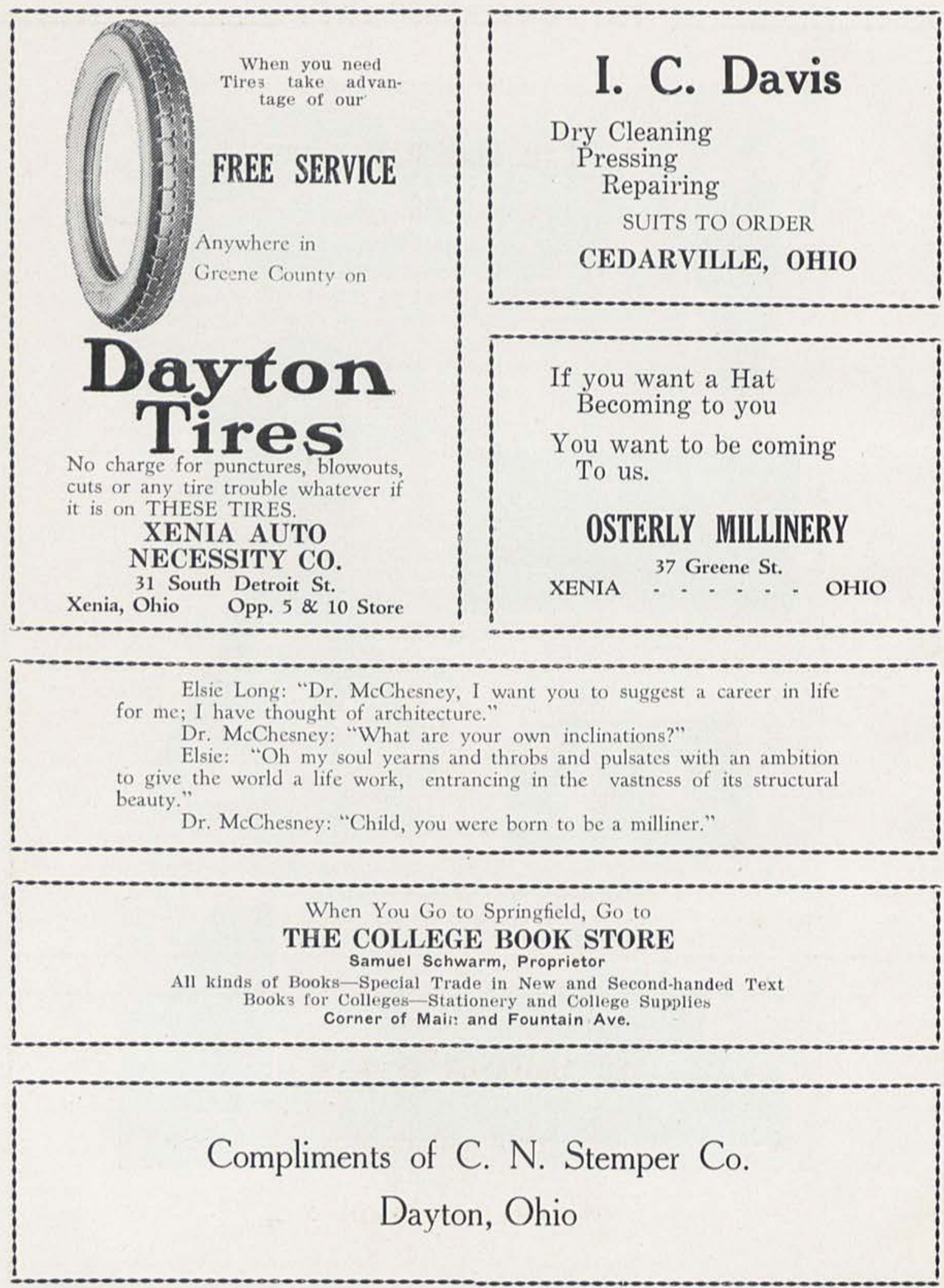

Ninety-two 


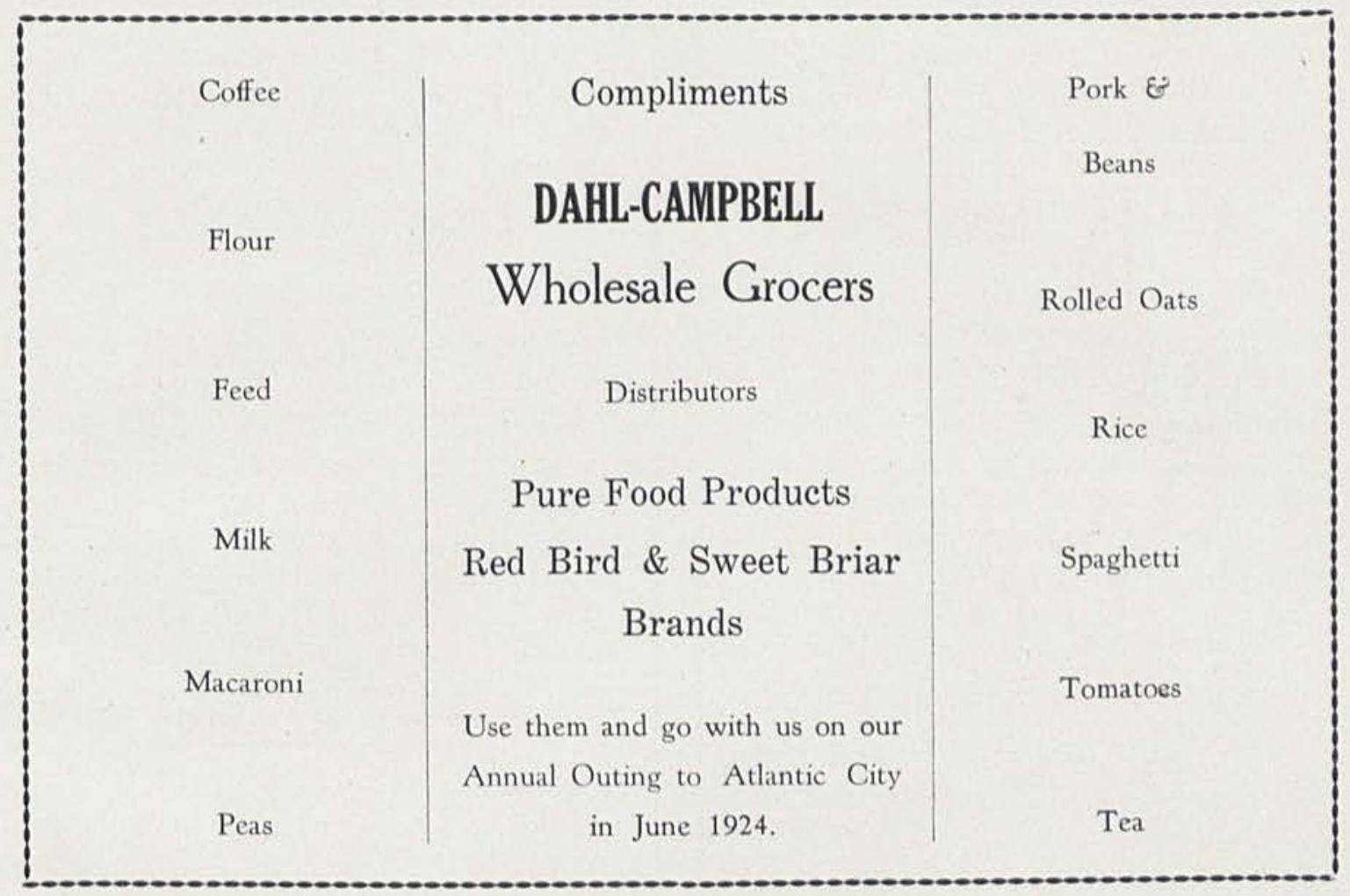

Among Recent Examination "Howlers"

"Things that are equal to the same thing are equal to anything else."

"A grass widow is the wife of a dead vegetarian."

"Oceania is that continent which contains no land."

"A vacuum is a large empty space where the pope lives."

"Parallel lines are the same distance all the way and do not meet unless you bend them."

"Louis XI was gelatined during the French Revolution."

"Horse power is the distance one horse can carry a pound of water in an hour."

\section{LEO ANDERSON, D. V. M.}

Veterinarian

CEDARVILLE, OHIO 

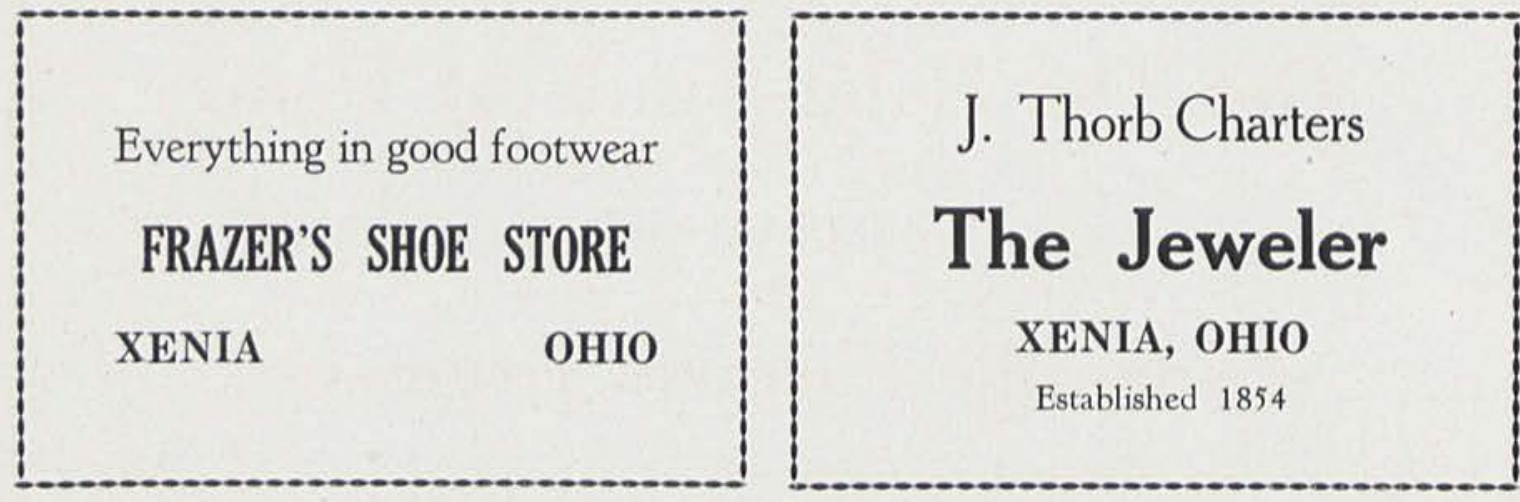

\section{ADAIR'S}

Furniture, Carpet, Stoves

Victor Victrolas

20-24 North Detroit St.

\section{XENIA, OHIO}

Old: "I'm writing to my best girl-what is a clever P. S. to add?"

Older: "Please burn this at once."

Charles Townsley: "I'll bring my saxaophone the next time I call. You like music don't you, Sweetheart?" the same."

She: "Yes, I do. But come just
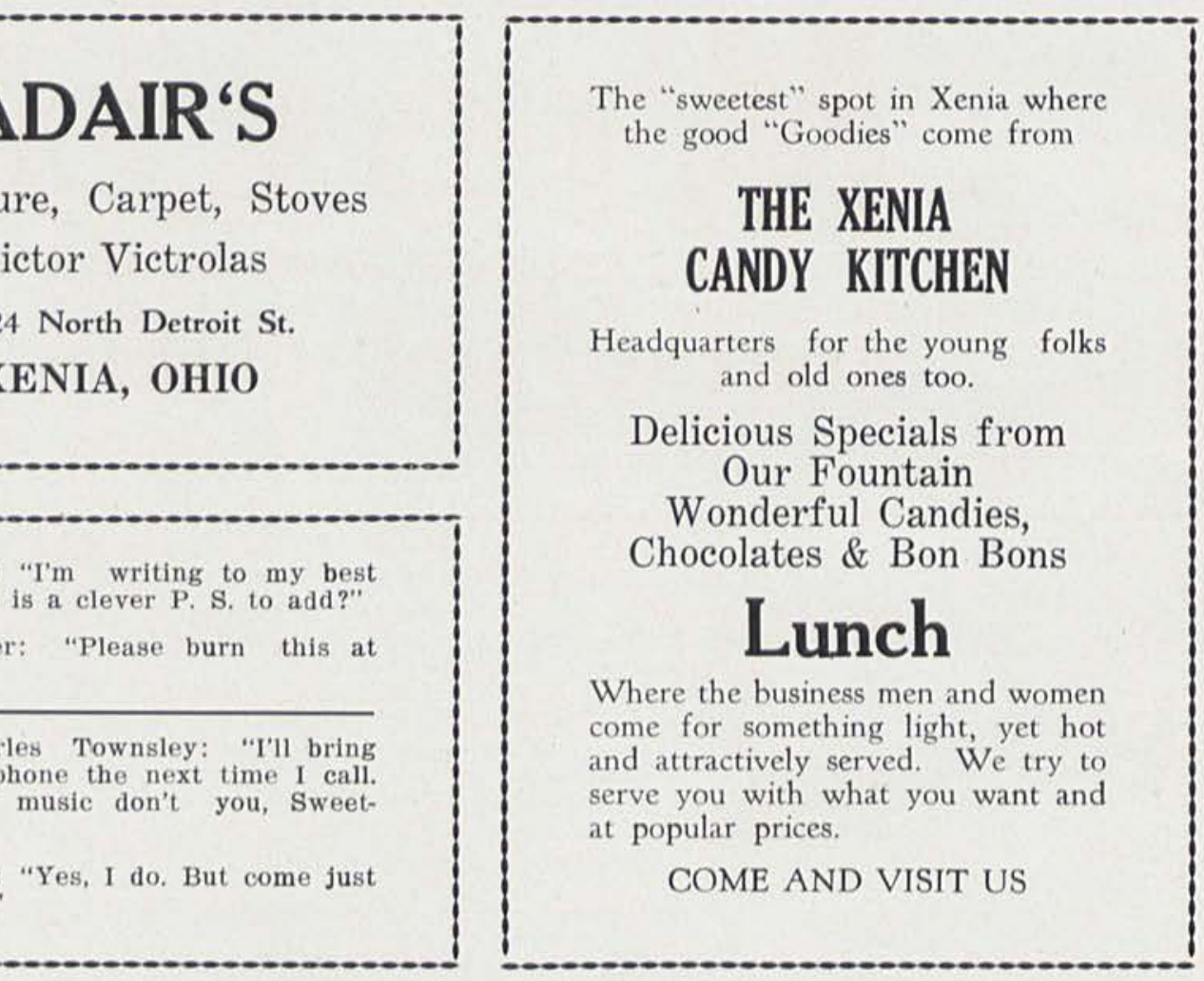

\section{QUALITY GIFTS}

BEST SCHOOL SUPPLIES

GIBSON GREETING CARDS

POPULAR SPORTING GOODS

DENNISON NOVELTIES

EDISON PHONOGRAPHS

\section{Geyer Book Shop}

6 SOUTH DETROIT ST.

XENIA, OHIO

If we havn't it or can't get it, it isn't 


\section{Get The Habit--Trade at Home Hardware, Fence Posts, Tile Feed, Coal, Cement}

If it's used on the farm-we have it

\section{Cedarville Farmers Grain Co.}

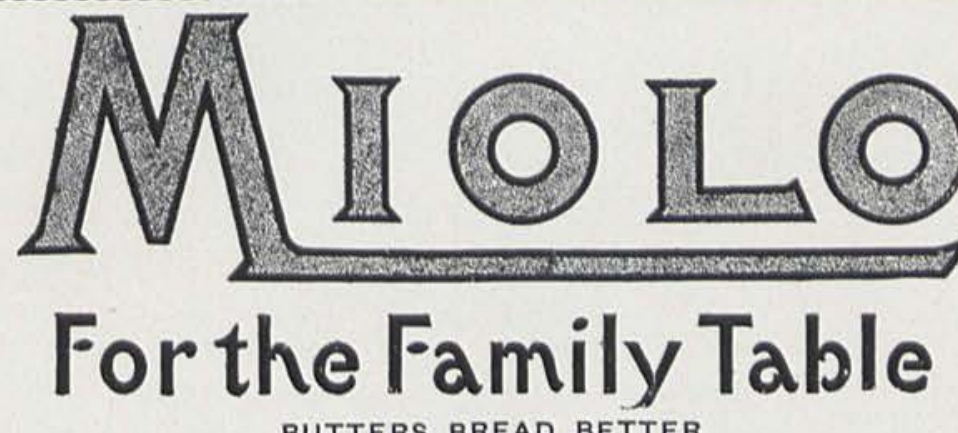

BUTTERS BREAD BETTER
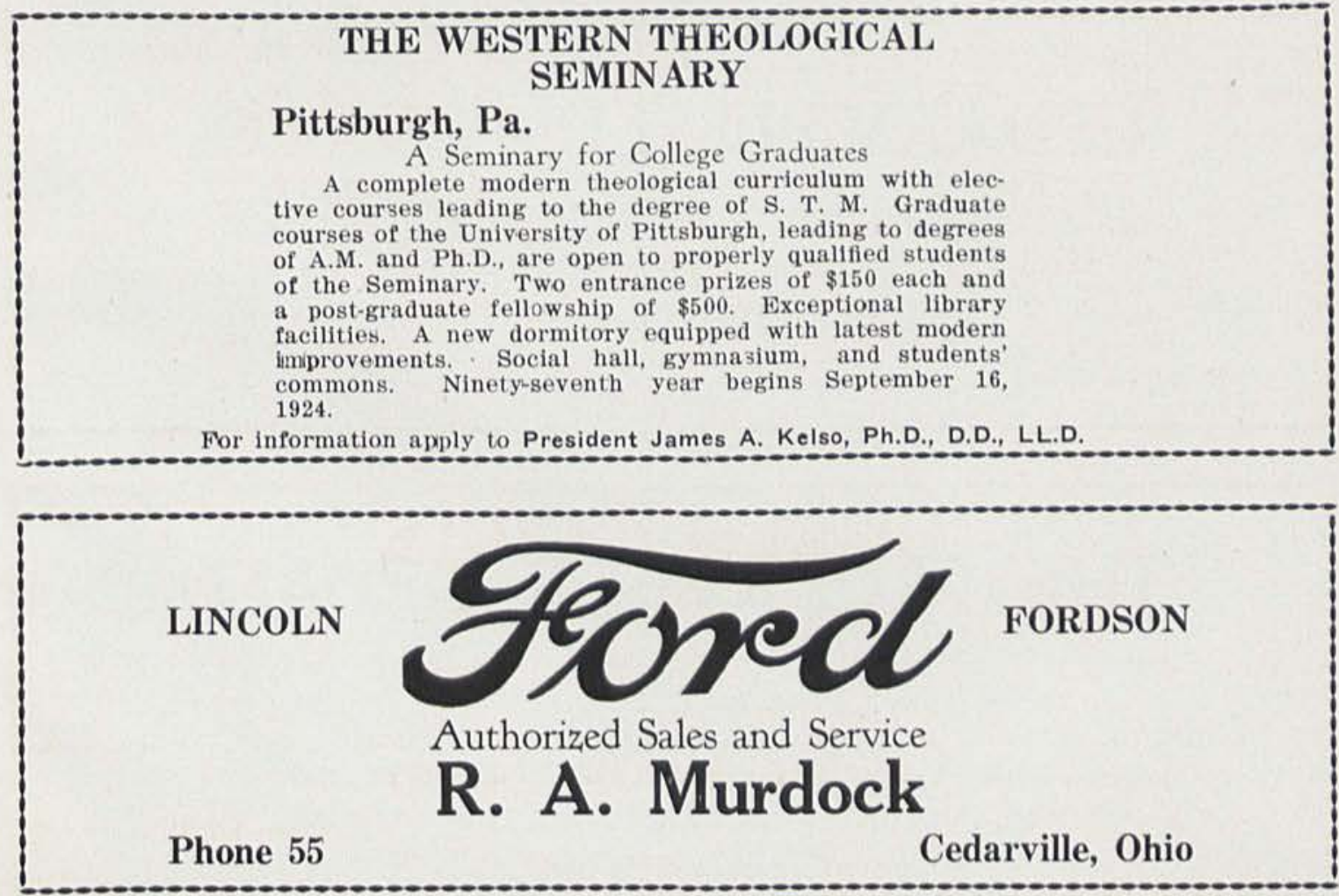

Ninety-five 


\section{E. MASTERS Groceryman}

Exchange Bank Building

Phone 2-44

Cedarville, Ohio

NEW MANHATTAN RESTAURANT

Our Motto

Quality and Service

Open day and night

8 North Detroit St. Xenia, O.

\section{BRIDGE BARBER SHOP}

All Work First Class

Ladies' and children's work a specialty

SMITH $\&$ WALTERS

CEDARVILLE

$\mathrm{OHIO}$

\section{CEDARVILLE LUMBER CO.}

Everything in Lumber, Mill Work, Building Material

Fence and Fosts

PHONE 33

\section{THE CEDARVILLE HERALD}

\section{Commercial \\ Catalogue \\ Job Printing}

Let us give you an estimate on your printing 
The CEDRUS 1924

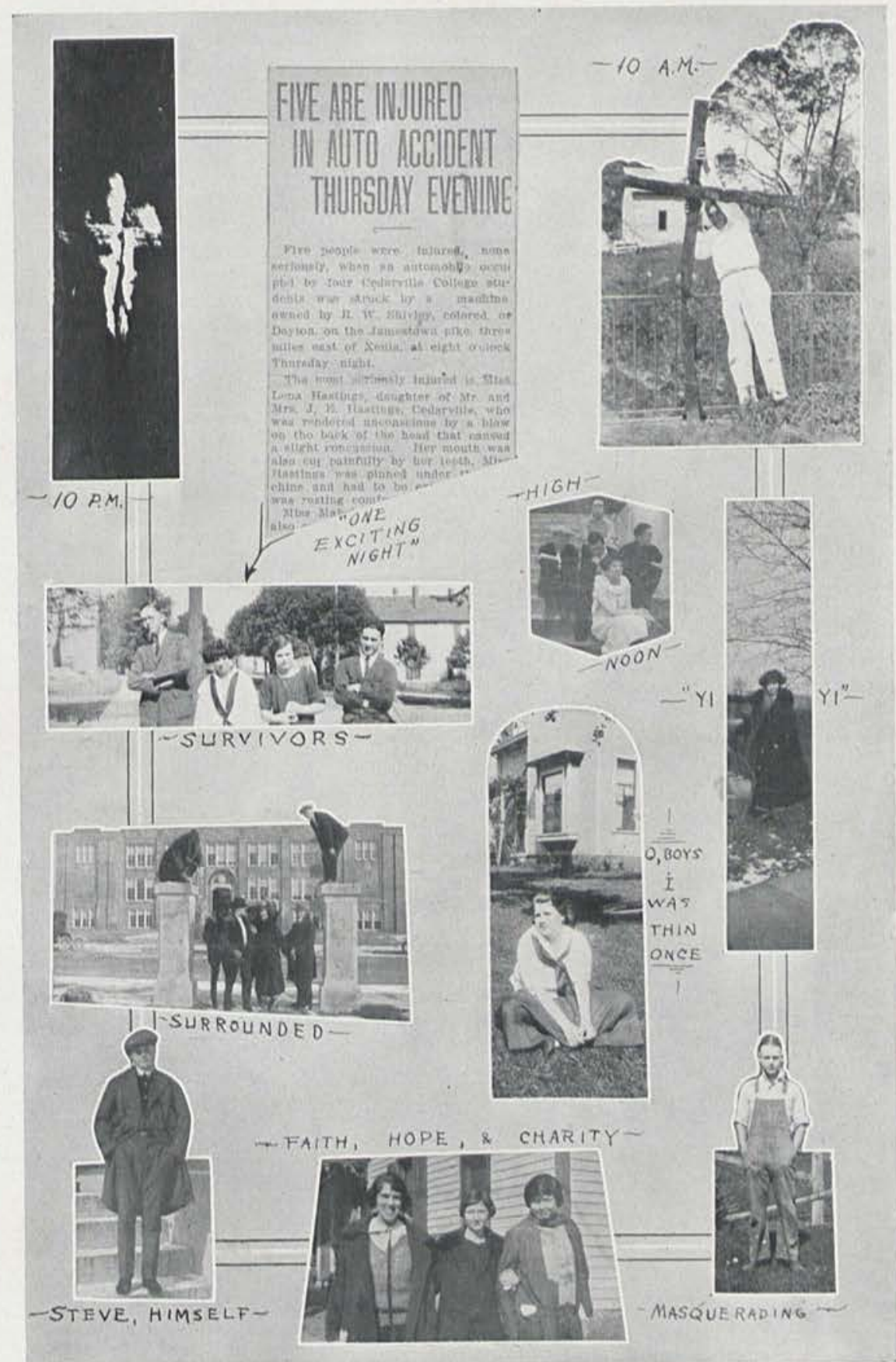


The CEDRUS 1924

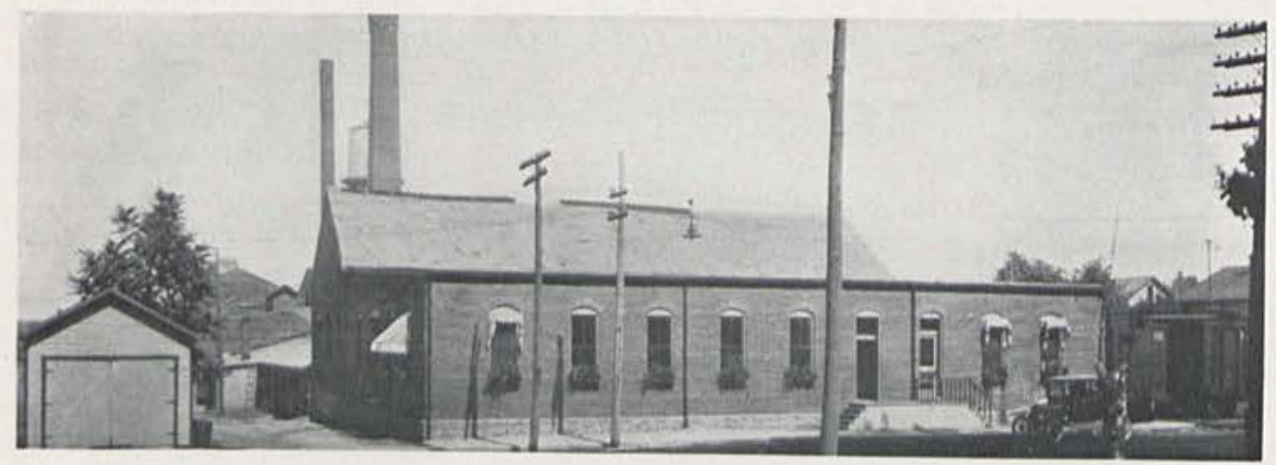

\section{The Hagar Straw Board and Paper Company}

This plant has been in Cedarville for a number of years and is Cedarville's largest manufacturing plant. It has been a boon to the village as it provides employment for a lumber of men, this in turn makes business better for the merchants and thus many are benefited by it. The present management is doing even more for the advancement of the plant than was done in previous years.

It is due largely to the support given the Cedrus by this Company that we were able to publish this book. It is with pleasure that we acknowledge the aid given, and our hope is that they may continue to enjoy business success for many years to come. Editor

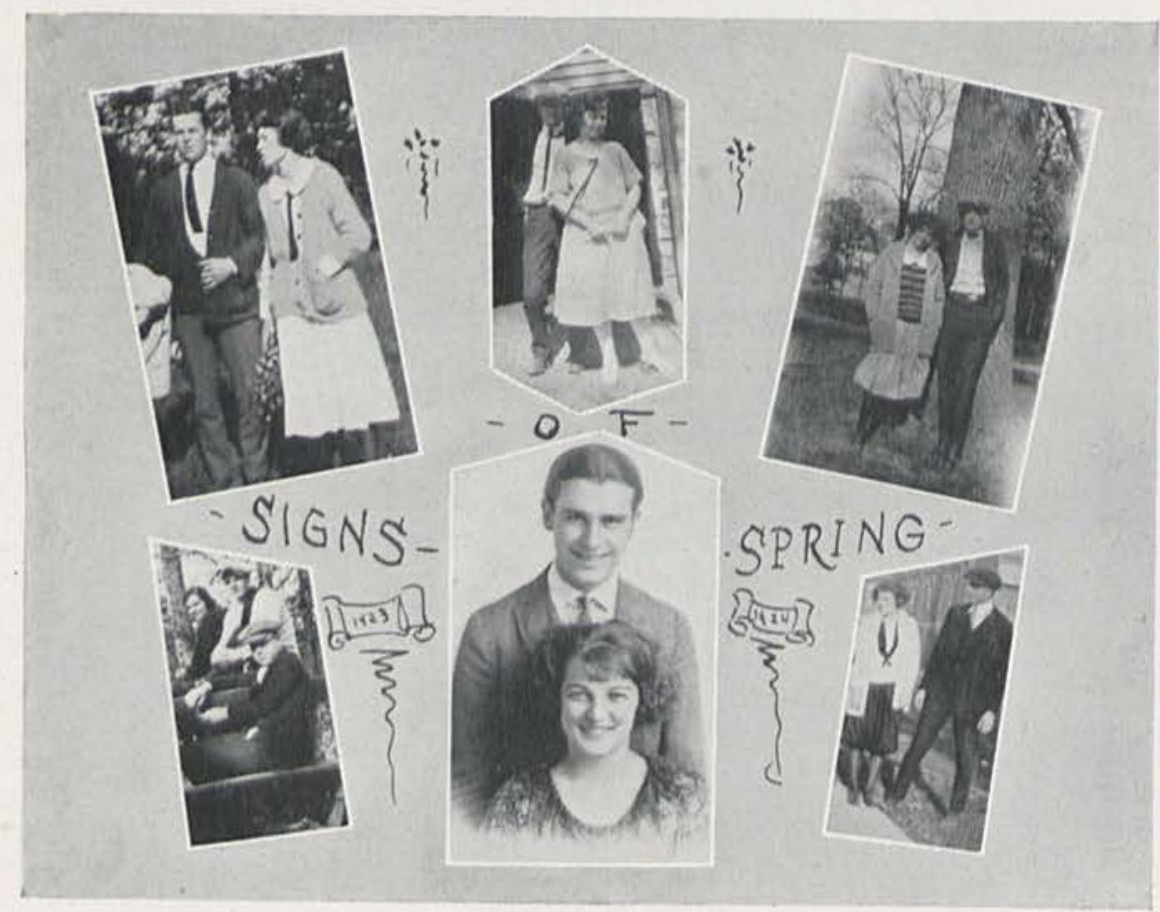




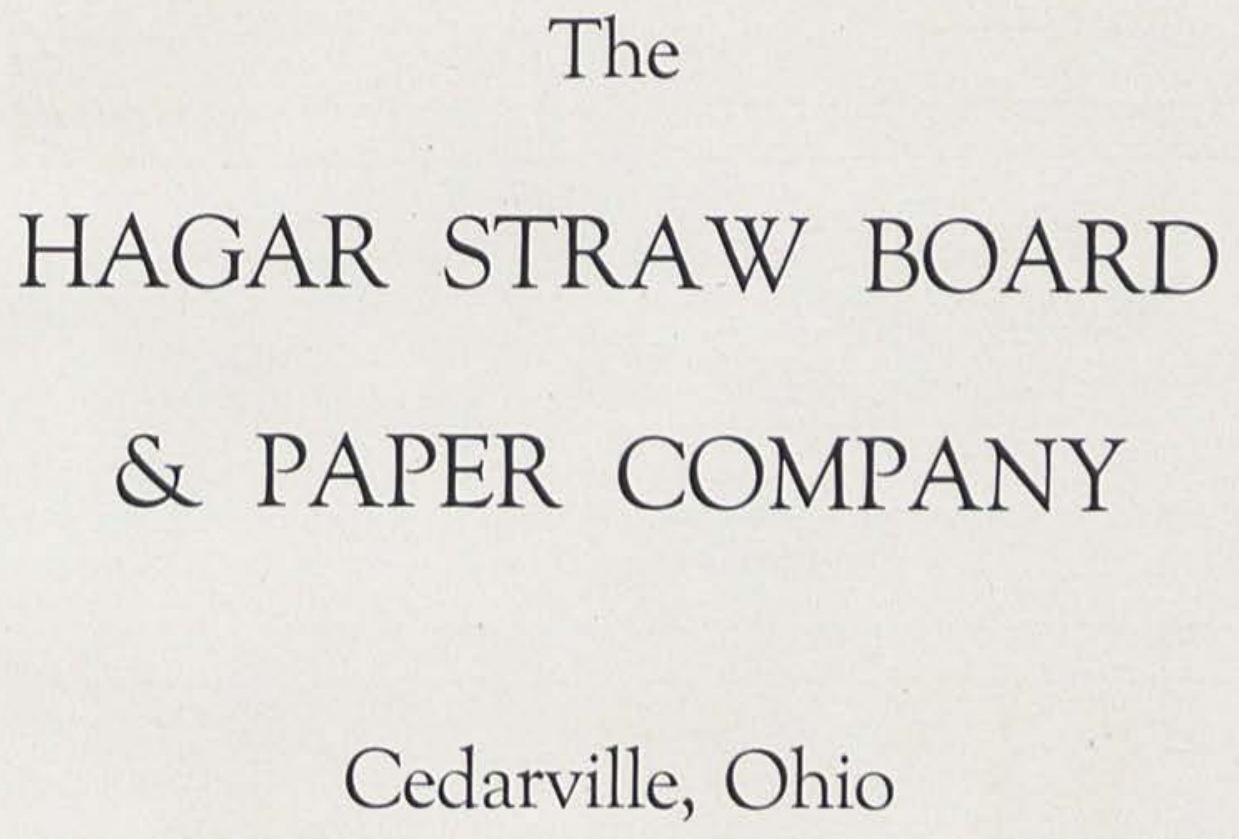

Fine Straw Board For Corrugating 

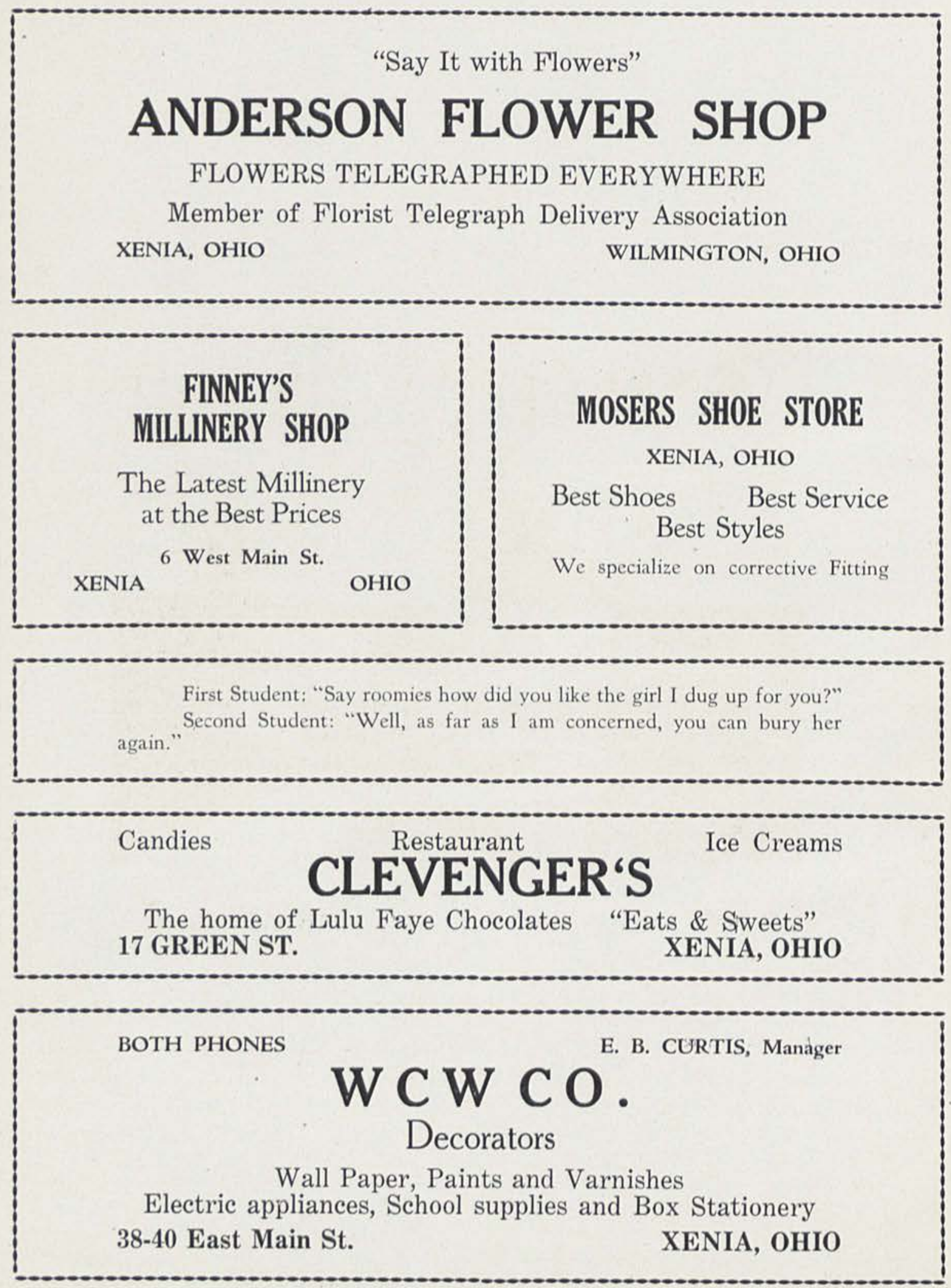
The CEDRUS 1924

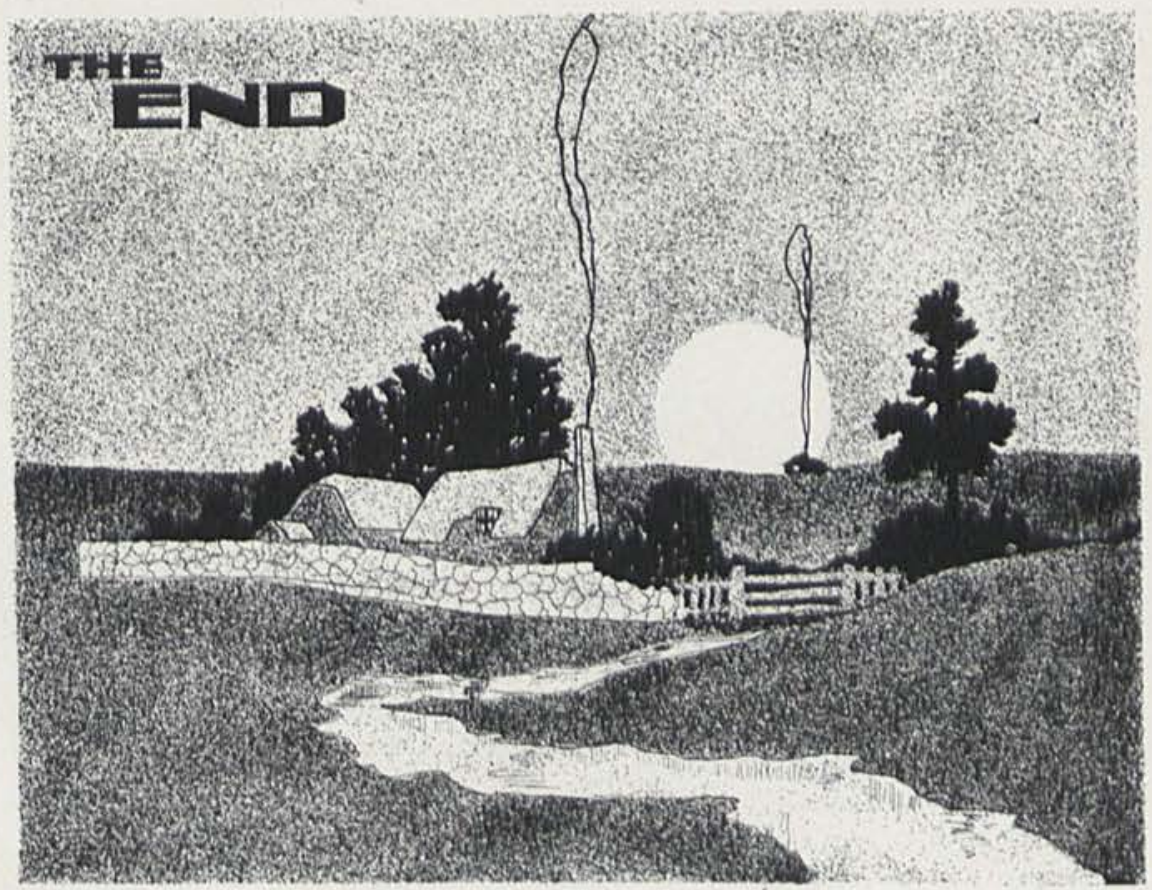


FAINTED BY

THE BROWN PUBLISHING COMPANY BLANCHESTER, OHIO 




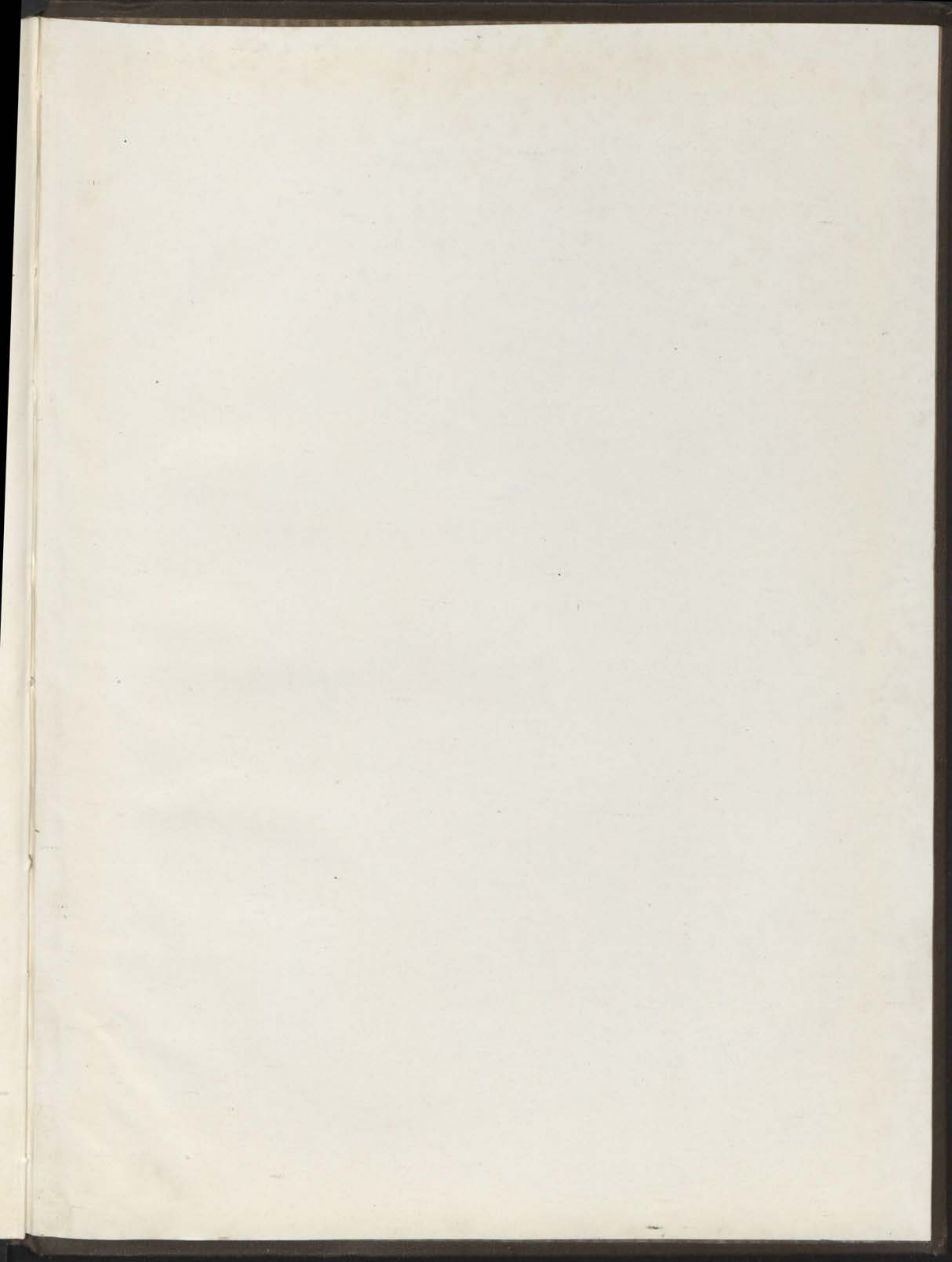




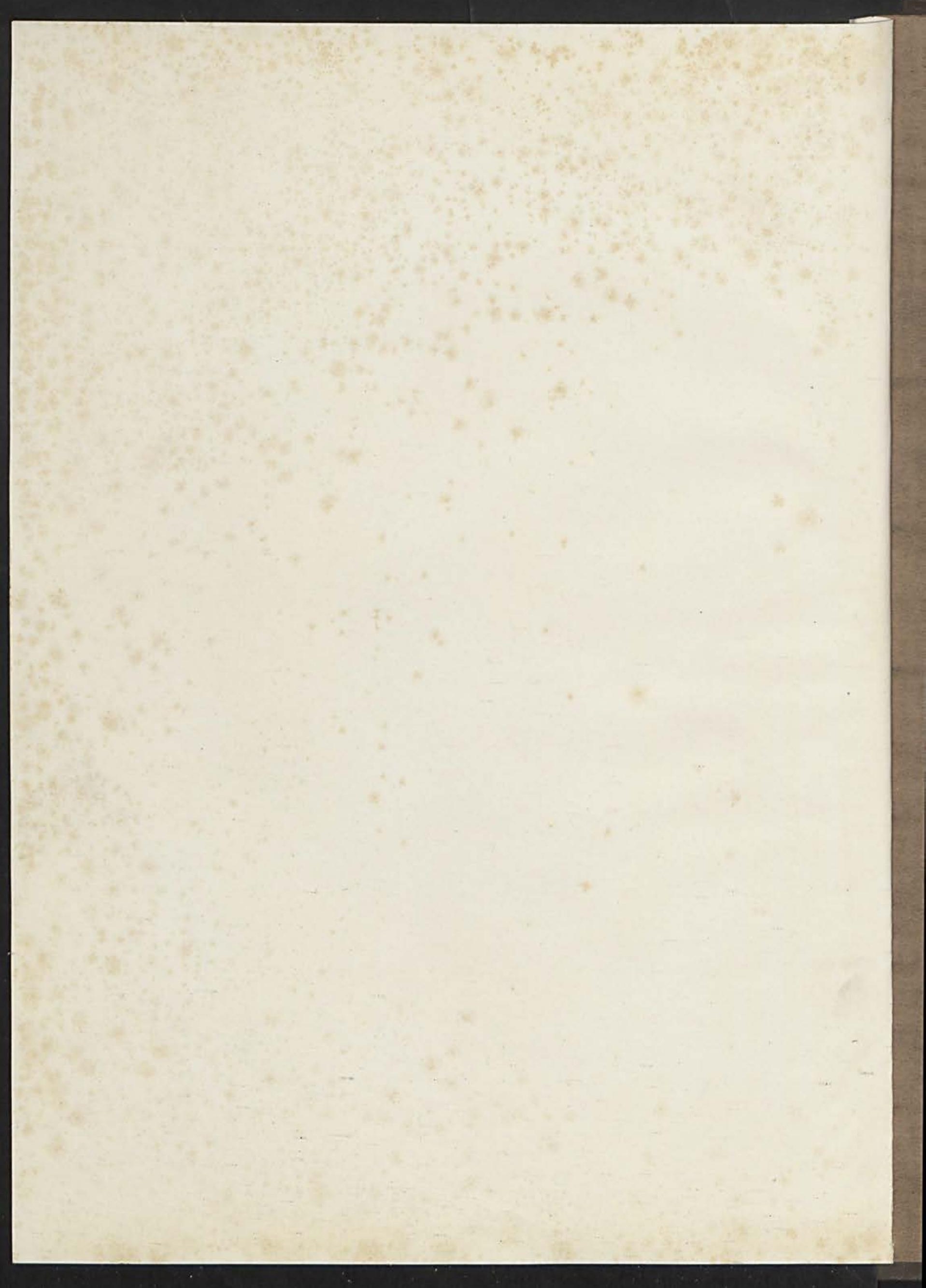




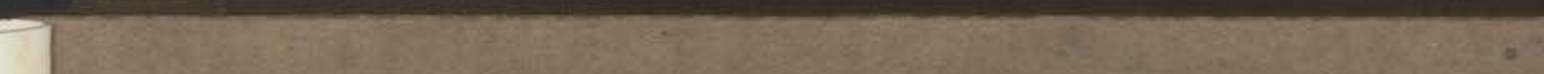



